THE LITTLE SHEEP MOUNTAIN COAL FIELD, DAWSON, CUSTER, AND ROSEBUD COUNTIES, MONTANA.

By G. Sherburne Rogers.

INTRODUCTION.

IOCATION.

The area known as the Little Sheep Mountain coal field is 24 to 30 miles wide from north to south and extends westward about 60 miles from the neighborhood of Terry, Mont. (See Pl. XIII.) It is bounded on the east by Yellowstone River and on the west by the tenth guide meridian. The total area is 1,440 square miles. The district extends from Yellowstone River to the top of the Missouri-Yellowstone divide. The coal outcrops run in a general eastwest direction, extending back from the river in the westward portion of the district owing to the slight dip of the rocks and the extensive dissection of the upland by Sunday Creek. The area does not constitute a structural or stratigraphic unit but is merely an arbitrary division of the southwestern portion of the large coal region which covers much of the eastern part of Montana and the western part of North Dakota.

\title{
FIELD WORK.
}

The Little Sheep Mountain field, in common with all the others in this vicinity, was examined with a view to the classification of the land and the valuation of that part underlain by coal or lignite. This necessitated tracing the outcrop of each bed and the determination of its exact position with regard to land corners. In the present work all beds 24 inches or more thick were mapped and located with respect to the nearest available section corner. A careful examination of each bed was made at many places, the number of points examined depending on the condition of the outcrop. In badland districts or where the coal is almost continuously exposed sections were taken about every half mile; where the bed is concealed, fewer examinations were made, but the average distance between sections is less than 1 mile. All mapping was done with a telescopic alidade and stadia rod, a continuous line of altitudes being carried from the 
railroad at Terry to the farthest corner of the field. The accuracy of this vertical control is therefore considerably greater than would have been possible with an aneroid barometer, and although it is by no means absolute it furnishes the only practicable method of determining the details of the structure of the region. The geologic boundaries were located by triangulation, and in several places this method was also used to establish a primary control for the alidade work.

The writer was assisted in the field by Alan Bruyere, L. E. Trout, and A. H. Sloan. The work was done under the general supervision of E. G. Woodruff, whose frequent aid the writer desires gratefully to acknowledge.

\section{PREVIOUS WORK.}

The only previous work in this field was a reconnaissance made by A. G. Leonard ${ }^{1}$ in 1906. In his trip from Glendive southwest to Miles City and then northwest to Glasgow he twice crossed the area under consideration, once south through range 47 and then northwest again along the.Jordan stage road.

Work in the district immediately south, around Miles City, was done in 1907 by a United States Geological Survey party in charge of A. J. Collier and C. D. Smith. ${ }^{2}$ The area adjoining on the east was examined by F. A. Herald, ${ }^{3}$ and the district in the vicinity of Glendive, north of the Terry field, by J. H. Hance ${ }^{4}$ in 1910. Detailed work has been done by C. T. Lupton, ${ }^{5} 50$ miles west, in the eastern part of the Bull Mountains, but this field is not so closely related to the Little Sheep Mountain field, either in structure or in variety of coal, as the immediately contiguous areas.

\section{LAND SURVEYS.}

The entire region has been or is being surveyed by the General Land Office. The townships along the Yellowstone were laid out and partly subdivided in 1881 to 1884 . Tps. 13 N., Rs. 48 to 51 E., were surveyed in 1900, except the two southernmost tiers of 'sections in Rs. 49 and $50 \mathrm{E}$. The townships lying between the tenth guide meridian and the Rosebud-Custer County line were surveyed and subdivided in 1901, except the eastern half of T. 10 N., R. 41 E., T. 9 N., R. 47 E., was surveyed and subdivided in 1895. Parts of

\footnotetext{
1 Leonard, A. G., The coal fields of parts of Dawson, Rosebud, and Custer counties, Mont.: Bull. U. S. Geol. Survey No. 316, 1907, pp. 194-211.

- Collier, A. J., and Smith, C. D., The Miles City coal field, Mont.: Bull. U. S. Geol. Survey No. 341, 1909 , pp. 38-61.

8 Herald, F. A., The Terry lignite field, Custer County, Mont.: Bull. U. S. Geol. Survey No. 471, 1912, pp. 227-270.

1 Hance, J. H., 'The Glendive lignite field, Dawson County, Mont.: Bull. U. S. Geol. Survey No. 471, 1912, pp. 271-283.

- Lupton, C. T., The eastern part of the Bull Mountain coal field, Mont.: Bull. U. S, Gẹoḷ. Survey No. 431, 1911, pp. 163-189.
} 
T. 10 N., R. 47 E., and T. 9 N., R. 46 E., were surveyed and subdivided in 1900 and 1901, respectively. T. 10 N., R. 45 E., and parts of T. 12 N., R. 51 E., were surveyed and subdivided in 1907. The remainder of the district-that is, the part in which land boundaries are represented by broken lines on the map (PI. XIII)-was surveyed in 1908, but the survey has not yet been accepted and township plats are not available. Eight different surveys have thus been made in the region. Of the 1,440 square miles. surveyed about 600 are unaccepted and 100 were surveyed before 1884, so that the markings of the corners in this portion are not satisfactory, but in the remaining 740 square miles the surveys are accurate and reliable.

\section{TOPOGRAPHY.}

\section{RELIEF.}

The maximum range of altitude in this region from the banks of the Yellowstone at Terry to the top of Little Sheep Mountain in T. 13 N., R. $47^{\circ} \mathrm{E}$., is about 1,300 feet. A zone of typical badlands roughly 10 miles wide runs down the western side of the district, across the southern and up the eastern side. These badlands are nearly impassable in places, for example, in the territory just northwest of Terry. Through this badland zone the larger streams have cut broad and fairly flat valleys, although they are at present invariably confined in a narrow inner gully. This feature is less conspicuous in the northern part of the district, where the topography is entirely different in character; gently rolling prairie land there predominates, with a few localities of somewhat greater relief. In places a stretch of prairie is thoroughly dissected by a system of deep, narrow coulees or small canyons, the width of which scarcely exceeds the depth. Steep, bare buttes, so characteristic of the badland zone, are rare, and where present they may generally be ascribed to a resistant cap rock protecting the underlying strata from rapid erosion. This cap is generally composed of the hard red clinker or natural terra cotta formed by the burning of the coal beds along the outcrop, a process which results in baking and partly fusing the overlying beds. Small knobs or mountains of unburned rock are, however, not uncommon in parts of this district; the sandstone composing them is coherent enough in places to form vertical cliffs, yet sufficiently heterogeneous to yield readily to wind sculpture into fantastic shapes. Little Sheep Mountain, the most prominent of these hills, is a landmark visible for a considerable distance.

The dissected remnants of at least three old river terraces may be recognized. The highest terrace lies on the southeast flank of Little Sheep Mountain at an altitude of 3,200 feet, and there is another on

$60385^{\circ}-$ Bu1l. 531-13-11 
the north divide of Cherry Creek at an altitude of about 2,800 feet. This high terrace is probably also represented in T. 10 N., R. 45 E., where a considerable area is covered by alluvium at an altitude only slightly greater than either of those mentioned above. The third terrace is best preserved near the bank of Yellowstone River in T. $10 \mathrm{~N}$., R. $49 \mathrm{E}$., where its altitude is 2,550 feet. In these places and in the others where the terraces may be recognized they are covered with a 20 or 25 foot layer of alluvial pebbles with an interstitial filling of fine gravel, sand, and silt. This type of terrace is practically infertile; but on the south side of the river, especially near Terry, the river terraces are more arable and are in some places comparatively rich.

\section{DRAINAGE.}

The greater part of the area is drained by Yellowstone River, which, having its source in the mountains 300 miles to the southwest, contains much water even in the dry season at the end of the summer. Among the more important of its tributaries rising in this district are Sunday Creek, which drains two-thirds of the whole area; Harris Creek; Custer Creek, running southeast from Little Sheep Mountain; and Cherry Creek, running east from the same locality. Both branches of Sunday Creek are practically perennial, although the flow almost ceases in late summer. The YellowstoneMissouri divide runs irregularly through T. 12 N., Rs. 41 to $45 \mathrm{E}$., so that the northern portions of these townships are drained by tributaries of Big Dry River, which flows north into the Missouri. Similarly, the townships of R. 41 E. overlap the divide between Sunday and Rorcupine creeks, so that their western portions are drained by tributaries of the latter stream. Some springs are found along Cherry and Custer creeks and water is always obtainable on Sunday Creek. A few springs are present at the heads of some of the other streams. Water may usually be found at a depth of 20 to 45 feet in the eastern part of the district, but in the extreme western part it is especially scarce, owing probably to the argillaceous character of the strata and partly perhaps to their eastward dip. The adjoining territory on the northwest is known as the Big Dry country, in which it is said that water is nearly lacking for half the year.

The general scantiness of water throughout this region is expressed in the stunted character of the vegetation. Cottonwoods are locally abundant along Yellowstone River and are found in the lower courses of all the creeks. On some of the higher hills, especially those near the river, pine and red cedar attain a small growth. The 500 square 
miles comprised in Tps. 11 and 12, west of R. 48 E., may, however, be described as treeless. Except for thickets of young cherry here and there in some of the deeper coulees, and a very few solitary cottonwoods or pines, there is no wood of any kind in that area. Timber for mining would therefore have to be transported a considerable distance. The settlers in this district must go nearly to Yellowstone River to obtain firewood, and consequently they use coal almost entirely. Sagebrush and cactus replace cottonwood farther up the creeks and in all the tributary coulees. The uplands are covered largely with buffalo grass, which forms excellent grazing for sheep, horses, and cattle. Numerous bands of sheep range through the whole region; horses are less abundant and cattle are scarce. A little dry-land farming is carried on, in some places with moderate success.

\section{CULTURE.}

The Chicago, Milwaukee \& Puget Sound Railway skirts the eastern border of the district, crosses the Yellowstone into the district at Calypso in T. 12 N., R. 50 E., and recrosses that river at Tusler in T. 9 N., R. 48 E. The Northern Pacific Railway runs along the east bank of the river, but does not enter the territory under consideration. Four stations on the former railway are located in the district, namely, Calypso, Saugus, Bonfield, and Kinsey, but none of these is a large settlement. Stone Shack, in T. 10 N., R. 45 E., is merely what its name implies; there is no settlement or even post office at the place. Satchwell post office is in T. 13 N., R. 43 E., just outside of the area. Terry, Miles City, and Forsyth are by far the most important towns in this general region, all being located on the two railroads mentioned above. Of these Terry, which has a population of 775 , is nearest to the area considered in this report, being just across the river in T. 12 N., R. 51 E., but Miles City, in T. 8 N., R. 47 E., is much the most important commercially of the three and has a population of 5,697 . Forsyth is in T. 6 N., R. 40 E. The most important wagon road in the district, the Jordan stage road, runs from Miles City up North Sunday Creek. Another road in fair condition extends from Miles City northwest up South Sunday Creek, and a third road goes north toward Little Sheep Mountain. A good road from Terry follows Cherry Creek. Numerous secondary roads and trails cross the area, though in many places the area can not be traversed by wagon, and in some places even horseback passage is difficult. 


\section{GEOLOGY.}

\section{STRATIGRAPHY.}

\section{AGE AND CHARAOTER OF THE FORMATIONS.}

The coal-bearing strata of this field belong to the Fort Union formation of the Tertiary system. Their identity was definitely established by fossils gathered by the writer and examined by T. W. Stanton and F. H. Knowlton. The bulk of the formation is made up of yellow beds, beneath which in most of the area a lenticular mass of dark shale and sandy shale, in places containing lignite, is correlated on the basis of lithology and stratigraphic relation with the Lebo andesitic member ${ }^{1}$ of the Fort Union as developed northeast of the Crazy Mountains. Underneath the Fort Union lies the Lance formation, concerning the age of which paleontologists do not agree, and which may prove to be either Tertiary or Cretaceous. Figure 3 shows a composite section of the strata exposed in this field, except the upper 500 feet of the Fort Union, which outcrops only on Little Sheep Mountain.

The general character of the formations in the region is shown in the following table:

Stratigraphy of the Little Sheep Mountain coal field.

[Section measured along Custer Creek from Yellowstone River to Little Sheep Mountain.]

\begin{tabular}{|c|c|c|c|}
\hline System. & Formation. & Character. & $\begin{array}{l}\text { Thick- } \\
\text { ness } \\
\text { (feet). }\end{array}$ \\
\hline Quaternary & & Coarse gravel, sand, and silt ... & $0-25$ \\
\hline Tertiary. & Fort Union. & $\begin{array}{l}\text { Sandstone, sandy shale, and clay shale, usually soft } \\
\text { and in many places incoherent; varying in color } \\
\text { from whitish yellow to dark yellow, with local beds } \\
\text { of light and dark gray; and containing numerous } \\
\text { thick and fairly pure beds of coal. } \\
\text { Iebo shale member. Shale and sandy shale, usually } \\
\text { incoherent, with hard concretions in many beds; } \\
\text { varying in color from grayish white to dark gray; } \\
\text { with local yellow beds; containing several coal } \\
\text { beds, commonly thin and impure; irregularly } \\
\text { deposited; forms badlands. }\end{array}$ & $0-340$ \\
\hline Cretaceous or Tertiary.. & Lance.... & $\begin{array}{l}\text { Shale and sandstone, usually grayish yellow but with } \\
\text { many gray beds and layers of brown sha.e; chiefly } \\
\text { incoherent but with local layers of compact shaly } \\
\text { sandstone. }\end{array}$ & 140 \\
\hline
\end{tabular}

\section{QUATERNARY SYSTEM.}

Extensive bottom land is formed along Yellowstone River, consisting chiefly of a sandy loam derived from the rocks over which the stream flows. Along most of the creeks, especially in their lower

\footnotetext{
1. Stone, R. W., and Calvert, W. R., Stratigraphlc relations of the Livingston formation of Montana: Econ. Geology, vol. 5, No. 6, 1910, p. 752 .
} 
courses, deposits of alluvium 20 feet thick occur in some places. This material was brought down when the gradient of the upper part of the stream was very high and deposited near its mouth or where the gradient was rather suddenly lowered, and now, with maturer development and increased drainage area, the creeks are cutting into this material and transporting it again more slowly to the river.

The remnants of three old river terraces at heights of 300,600 , and 1,000 feet above the river are mentioned above. The pebbles on these terraces are well waterworn and usually more or less flattened; their greatest diameter is commonly as much as 6 inches. The interstitial sand is chiefly quartz, generally in angular grains. An examination of the pebbles covering an area of about a square yard resulted in the identification of the following: Quartzite, vein quartz, jasper and chalcedony, sandstone, quartz conglomerate, granite, trachyte, and olivine basalt.

\section{TERTIARY SYSTEM. \\ FORT UNION FORMATION (EOCENE).}

GENERAL CHARACTER.

Lithology and thickness.-The section given below of a portion of the Fort Union strata is typical of the great bulk of the formation in this district. For the most part it is made up of soft material; beds entirely incoherent, however, are rare, and compact sandstones are hardly more common. These more resistant sandstones in many places cap mounds of soft material and produce the curious pinnacles characteristic of the semiarid regions. In some places large resistant cylindrical concretions occur in a soft sandstone in streaks that run several hundred feet. These concretionary

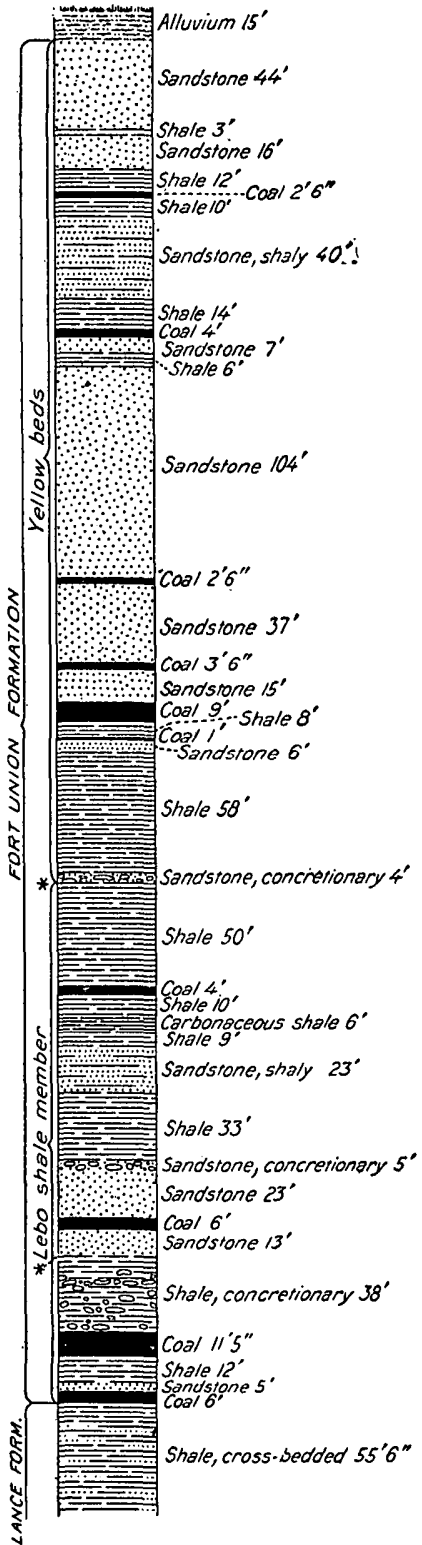

FIGURE 3.-Stratigraphic section showing interfingering of yellow beas of Fort Union formation and Lebo shale member. Lower 279 feet measured northwest from NW. $\frac{1}{8}$ sec. 9, T. 12 N., R. 51 E.; upper 358 feet measured north from sec. 9, T. 13 N., R. 51 E. (See fig. 4, p. 170.) Between points in section indicated by asterisks $\left(^{*}\right)$ the strata consist of alternating ycllow sandstones and dark shales, reprosenting tho interfingering of the yellow beds and the Lebo shale member. This zone is shown on the map (Pl. $\mathrm{XIII}$ )as part of the Lebo shale member. 
masses are invariably split by well-developed transverse joints, but the softness of most of the other beds precludes the formation of joints. The predominant color is some shade of yellow, but lightgray and less commonly dark-gray strata occur. In several places a lavender-gray was noticed. Microscopic examination reveals small clastic grains of coal, which doubtless gave rise to this tint.

Certain of the gray beds of this formation contain scattered crystals of gypsum of the variety known as selenite, which range in size from 1 to 6 inches in longest diameter. Many of these crystals are beautifully etched. This mineral is sometimes found also in the coal beds, in one place being associated with typical fibrous aragonite, the fibers of which were perpendicular to the bedding of the coal. Wavellite, the hydrous aluminum phosphate, was found at one place in bluish-white radiating needle-like crystals deposited in the joint cracks of a hard yellow shale. Quartz, in well-formed crystals onefourth inch long, occurs in a similar way in several places.

In most of the area there occurs beneath the soft yellow beds just described a lenticular mass of darker shale and sandy shale, containing coal in places, which on the basis of lithology and stratigraphic relations is correlated with the Lebo andesitic member of the Fort Union formation as developed northeast of the Crazy Mountains. In the region considered in this report these beds consist chiefly of shale, and the andesitic character is not as conspicuous as in the Crazy Mountains; hence this basal member is here called the Lebo shale member.

The general characteristics of the yellow beds which compose the greater part of the Fort Union formation in this area are shown by the following section:

Section of the yellow beds of the Fort Union formation measured in the southeast part of T. 11 N., R. $49 E$.

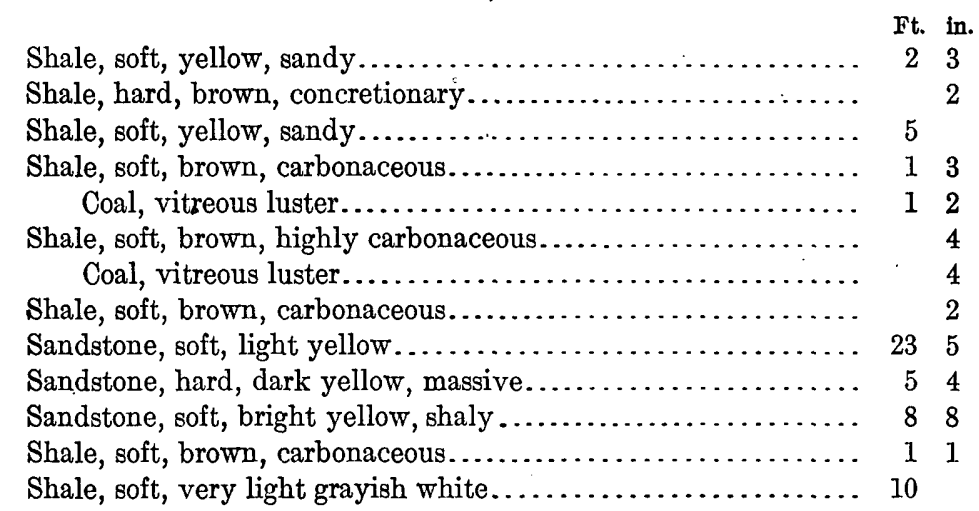

Sandstone, yellowish white, slightly shaly, containing numerous light-brown harder concretionary masses, becoming more whitish and more shaly at the top.......................... 
Sandstone, hard, brown, massive......................

Sandstone, soft, dirty white, shaly, with harder concretionary layers of the same color...............................

Sandstone, soft, yellowish white, shaly, with a few hard brown

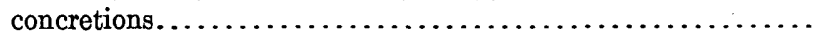

Sandstone, soft, light yellow, shaly, with several hard yellow concretionary layers.

Composition.-Nearly all these beds are impure arkosic sandstone or shale. In the arkosic sandstone the feldspar, commonly kaolinized, may often be recognized with a hand lens, and flakes of muscovite may frequently be detected with the naked eye. Calcareous shale and sandstone layers occur, however, although the presence of the carbonate is difficult to detect in the field. A hard greenishblack layer resembling a dolerite proved under the microscope to consist. of small angular fragments of quartz and feldspar grains set in a matrix of sericite and calcite, but this facies is not common. Thin sections were made from several typical beds and revealed the general angular or subangular character of the grains, which are chiefly quartz and feldspar. Within 40 feet of the base of the yellow beds of the Fort Union formation in secs. 20 and 29, T. 11 N., R. $50 \mathrm{E}$., a lenticular bed of conglomerate occurs. The pebbles are of dark-yellow sandstone and range from 1 to 12 inches in diameter; the larger ones are generally angular, whereas the smaller are either subangular or rounded. The interstitial filling is a gray sand, some grains being as large as 1 millimeter in diameter, and the whole constitutes a hard and compact rock. In thin section it is seen that this sand is chiefly feldspar and quartz. The larger grains are plagioclase, all of them angular and many retaining the original crystal boundaries. The most surprising feature is the almost entire absence of kaolinization. The smaller grains, which are chiefly orthoclase and quartz, exhibit the same characters; they are set in a matrix of very fine material, largely kaolin. Conglomerates megascopically similar have been found in other localities at or near this horizon.

Origin.-The irregular way in which this conglomerate layer forms swirls and detached lenses in the overlying material, together with the characters of its components, indicates fluvial depositionstrong currents and fairly shallow water. Among other structural peculiarities, suggesting continental origin, noted in this formation at various places in the district may be mentioned mud cracks, ripple marks, and cross-bedding, all best preserved in the more indurated beds. The small flattened clay balls which are generally indicative of continental deposition also occur in places. 
Fossils.-The Fort Union age of these beds has been well determined in adjacent areas. It was amply confirmed by the following fossils collected by the writer and identified by T. W. Stanton:

One and three-fourths miles northeast of Terry.

Viviparus trochiformis $M$. and $\mathrm{H}$.

Campeloma multilineata $M$. and $H$.

Goniobasis tenuicarinata M. and $\mathrm{H}$.

Physa sp.
Sec. 2, T. 12 N., R. 49 E.

Unio priscus M. and H.?

Unio sp.

Vertebra of a turtle.

\section{LEBO SHALE MEMBER.}

General character.-The Lebo shale member, the basal part of the Fort Union formation, is composed of very irregularly deposited masses of shale with local arkosic sandstone. Except for numerous irregular and discontinuous layers of hard ferruginous concretions and for a few fairly hard and generally massive sandstones these beds are soft and practically incoherent. The rapid erosion which they undergo may be ascribed to their general softness, to .which, with the presence of the harder layers, is due the formation of the badlands so characteristic of the Lebo member. The land underlain by these beds is generally very poor for farming. The prevailingly argillaceous character and perhaps also the abundance of ferruginous concretions are doubtless the reasons for this general sterility. The influence of the member on topographic features is thus well marked. Moreover, the beds are prevailingly gray in color; yellow and white bands occur, but they are comparatively thin, so that the member differs from the formations above and below it and may be easily identified in the field. The following stratigraphic section is typical:

Section of Lebo shale member in secs. 21 and 29, T. 11 N., R. $49 E$.

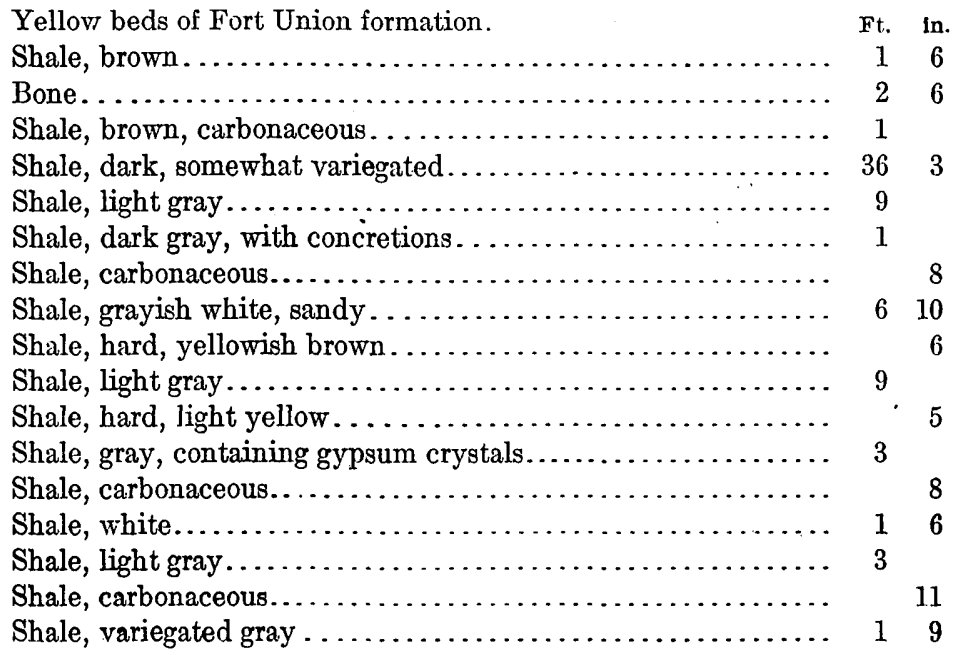




\begin{tabular}{|c|c|c|}
\hline & Ft. & \\
\hline andstone, hard, yellow, massive. & 4 & \\
\hline Shale, yellowish white.......... & 16 & \\
\hline Shale, yellowish white, arkosic, sandy, compact..... & 3 & \\
\hline $\begin{array}{l}\text { Shale, variegated light and dark, with many irregular and dis- } \\
\text { continuous layers of dark-brown concretions................ }\end{array}$ & 86 & \\
\hline $\begin{array}{l}\text { Sandstone, grading from yellow white at the top to dark gray at } \\
\text { bottom, shaly } . \ldots \ldots \ldots \ldots \ldots \ldots \ldots \ldots \ldots \ldots \ldots \ldots \ldots\end{array}$ & 18 & 9 \\
\hline Shale, dark gray, with numerous ferruginous concretions....... & 15 & 4 \\
\hline Sandstone, soft, yellowish gray $\ldots \ldots \ldots \ldots \ldots \ldots \ldots \ldots$ & 7 & 11 \\
\hline Sandstone, hard, dirty yellow. . . . . . . . . . . . . . & 4 & \\
\hline $\begin{array}{l}\text { Sandstone, yellowish gray, shaly, containing many irregular } \\
\text { and discontinuous layers of ferruginous concretions........... }\end{array}$ & 79 & 6 \\
\hline 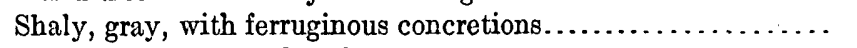 & 2 & \\
\hline ad shale...................... & 10 & \\
\hline with bone (section $293, \mathrm{Pl}$. XII)... & 11 & \\
\hline formation. & 338 & \\
\hline
\end{tabular}

Stratigraphic position.- The distinctive appearance of the Lebo facilitated the recognition of the fact that the member is wedge or fan shaped. In the eastern part of T. 12 N., R. 51 E., it is lacking. (See fig. 4.) Coal U, which is taken as marking its base, is here directly overlain by rocks with the lithologic character of the yellow beds of the Fort Union and underlain by light yellowish-gray beds belonging to the Lance formation. In the SW. $\frac{1}{4}$ NE. $\frac{1}{4}$ sec. 9, T. 12 N., R. 51 E., about 12 feet of dark-gray shale overlie this coal bed. Half a mile to the west yellow and gray strata, alternating in about. equal quantity, overlie coal U. A mile farther west over 200 feet of dark-gray material and only a few beds of dirty yellow overlie it. In sec. 29, T. 11 N., R. 50 E., 7 miles southwest of the lastmentioned locality, 250 feet of dark shale lie between coal $U$ and the yellow phase of the Fort Union, and on Custer Creek, 7 miles farther southwest, about 340 feet. Westward from this place there was no opportunity for measurement in the field. Twenty miles farther west the coal bed which marks the lower limit of the Lebo is absent. In T. 9 N., R. 43 E., a coal outcrops, which in T. 12 N., R. $41 \mathrm{E}$., is only about 100 feet beneath the yellow beds of the Fort Union. Notwithstanding this fact, however, this bed resembles bed $U$ in general character, being commonly thick and composed for the most part of bone and shale. If this coal be accepted as the equivalent of bed $U$, the shale is lenticular; otherwise it is fanshaped, of an unknown thickness in the western part of the district but probably not greater than 350 or 400 feet. This latter alternative, in view of the petrologic composition of the shale as given below, appears the more probable. In either case, the eastern limit of deposition, so far as this area is concerned, is located in sec. 11, T. 12 N., R. 51 E., where coal $U$ is directly overlain by the yellow beds of the Fort Union. 


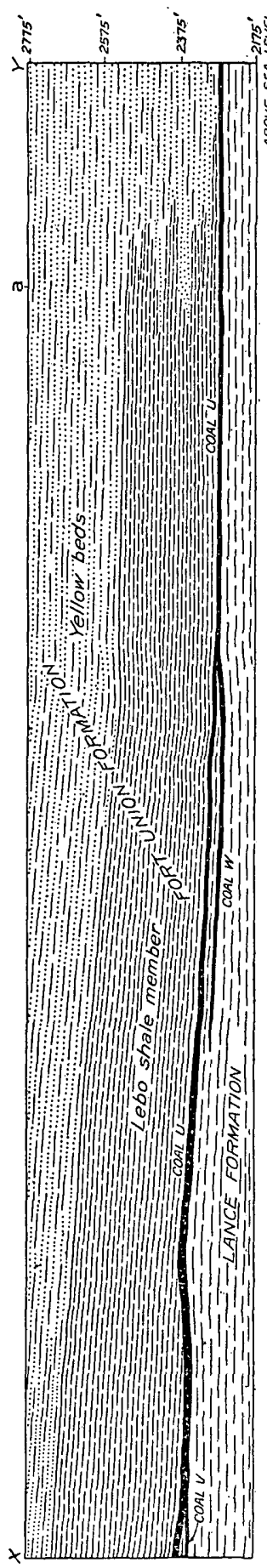

Structural features.-A noticeable feature of the Lebo member is the very irregular character of the beds, which change abruptly in a horizontal direction. The accompanying section represents the member in one place only; at a distance of a thousand feet on either side many of the beds change in color and in texture. Scattered throughout the Lebo are many lenses of white sand, few of which are more than 2,000 feet long and perhaps 60 feet thick, and many of which are only 200 feet long and 10 or 20 feet thick. Some of these lenses lie oblique to the surrounding beds, in places with an erosional unconformity beneath them. (See fig. 5.) All of them are strikingly cross-bedded. The latter feature, together with ripple marks and mud cracks, is very common throughout the member. The lenticular and irregular character of the strata extends as well to the coal beds, most of which are dirty, and none of which, with the exception of bed $U$, are of any great extent.

Petrologic and other evidence as to age.The Lebo member was first described from the vicinity of the Crazy Mountains, ${ }^{1}$ about 175 miles west of the area under consideration. It was interpreted as an outfingering of the Livingston formation, which is composed of andesitic, detrital, and tuffaceous material. This intercalated fan extends eastward to the Bull Mountains, where it was mapped by C. T. Lupton. ${ }^{2}$ Between the Bull Mountain field and the district discussed in this paper the beds are raised in a gentle anticline and the overlying yellow beds of the Fort Union are eroded, so that there is no way of actually tracing the Lebo member from the one field to the other. A petrographic examination of these beds reveals the fact, however, that they are largely derived from

1 Stone, R. W., and Calvert, W. R., Stratigraphic relations of the Livingston formation of Montana: Econ. Geology, vol. 5, No. 6, September, 1910, pp. 752 et seq.

Lupton, C. T., The eastern part of the Bull Mountain coal field, Montana: Bull. U. S. Geol. Survey No. 431, 1811, pp. 163-189. 
.a basic igneous rock. Because of this fact, which is consonant with the stratigraphic evidence, this fan-shaped mass, pinching out at the east, is considered to represent the Lebo member.

The Lebo member on the northeastern flank of the Crazy Mountains is a derivative of an andesite. Microscopic examination showed that locally it is a nearly pure tuff, but that it generally contains a considerable amount of plagioclase and that the whole is set in a fine chloritic groundmass. Fragments of hornblende and augite are also common, and in places there is a considerable admixture of quartz. Eight thin sections of material that was collected from the dark shale of the district discussed in this paper were examined

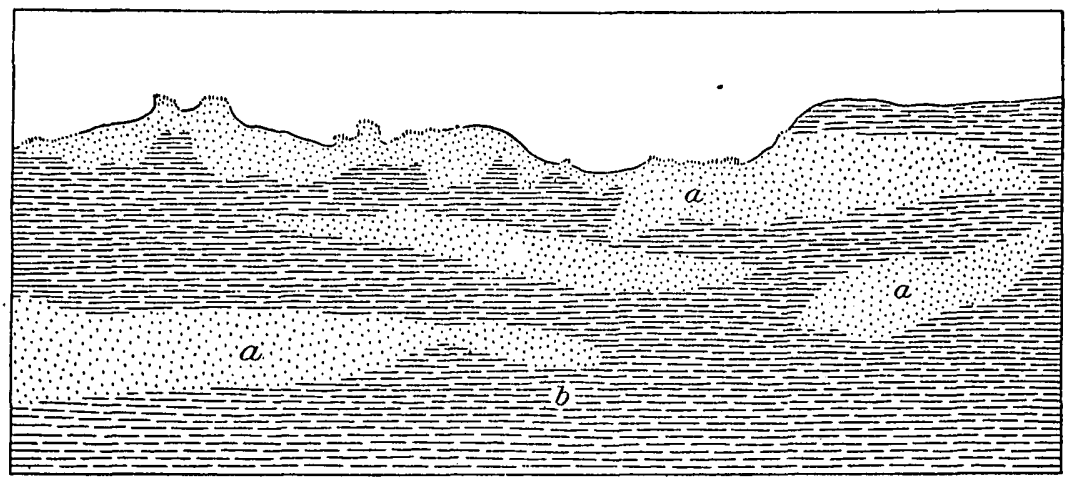

Figure 5.-Diagram showing relations of the lenses of tuffaceous sand in the Lobo shale member of the Fort Union formation. $a$, White tuffaceous sand; $b$, dark shale.

by the writer. Two of them were fine-grained dark-gray shale, so fine in fact that the microscope revealed no recognizable grains. They seem to consist of kaolin, stained brown by iron oxide, and the shale may have been derived from almost any kind of an igneous rock. Three slides were made from the grayish sandy lenticular material mentioned above, collected at two places about 10 miles apart, in T. 9 N., Rs. 42 and 43 E. All three specimens are decidedly tuffaceous in character and contain about 50 per cent of angular, subangular, and rounded fragments of a brown volcanic glass, generally more or less devitrified and altered. Quartz in small angular grains makes up about 40 per cent, and the remainder consists chiefly of kaolin and chlorite. Although the quartz indicates a considerable admixture of foreign material, this would be expected to occur in the material at a distance of 175 miles from its supposed source. One slide was made from a fine-grained, sandy, yellowishgray rock, which also revealed the presence of some volcanic glass, but the rock consisted chiefly of very small fragments of chloritic material with considerable quartz. Finally, two sections of sandy 
shale, partly baked by the action of a burning coal bed, were examined. Their original character was of course largely destroyed, but fragments of fresh green augite were identified in both of them. The sandy white material is thus derived directly from an andesitic flow; all the other rocks examined which were coarse enough to admit of study indicate a derivation, in. large part at least, from a basic igneous rock; two sections of shale were too fine to warrant an opinion as to their origin, but their evidence is not adverse. Furthermore, specimens of the yellow Fort Union strata above and of the Lance below were examined, and all indicate a probable derivation from a much more acidic rock; at least it may be said that they differ decidedly from the dark shale.

The following fossils collected by the writer from the. Lebo member in sec. 21 , T. 12 N., R. 50 E., and identified by F. H. Knowlton, are of Fort Union age:

Sequoia nordenskioldi Heer.

Populus amblyrhyncha Ward.

Sapindus grandifoliolus Ward.
Aralia notata Lesquereux.
Populus sp. Newberry.
Cocculus haydenianus Ward.

Interpretation.-Because of this concurrence of the stratigraphic and petrologic evidence, therefore, it has seemed advisable to classify these beds as the Lebo shale member. According to this hypothesis a large part of the material has been transported from the region west of the Crazy Mountains, although a considerable increment of foreign detritus has been received along the route. The striking cross-bedding and the great irregularity in deposition argue for a fluvial origin, and the angularity of the grains themselves offers a similar suggestion and precludes the possibility of any long eolian transportation. Possibly the lenses of white sandy tuffaceous material described above represent the ancient stream courses. These lenses are numerous and generally of small size; many of them lie at a small angle across the strata and all are strikingly cross-bedded. (See fig: 5.) It would not be expected that recent erosion, forming badlands, would expose an old river course with its meanders for any great distance; the recent gullies would cut across at all angles and the exposures of the old alluvium would pinch out abruptly. The shorter lenses would then represent an approximate cross section of the old channel, whereas the longer ones might be interpreted as more or less complete approaches to a longitudinal section.

\section{CRETACEOUS OR TERTIARY SYSTEM.}

LANCE FORMATION.

Character and thickness.-The Lance, which is the lowest formation exposed, is confined in the eastern part of the field and occurs in a conspicuously flat zone along the river valley. This lack of 
relief is apparently due rather to the fact that the belt is located along the lower courses of the creeks than to any qualities inherent in the formation itself. At both Miles City and Forsyth, for example, it forms high abrupt terraces and appears to give rise to a topography similar to that of the Fort Union. In these terraces the variegated aspect of the formation is well brought out, a feature which is somewhat obscured in the district described in this report. Grayishyellow layers appear to predominate slightly over the gray, but the yellow is seldom of the clear tint which is characteristic of the Fort Union, and the gray beds in places assume a very dark shade. They are chiefly incoherent, but heavy compact arkosic sandstones are numerous and irregular layers of the dark-brown concretions which were found in the Lebo shale member of the Fort Union are not uncommon.

The Lance formation in this district shows greater regularity in deposition than does the Fort Union. It is believed that the following stratigraphic section is typical:

Section of upper portion of the Lance formation, in secs. 24 and 14, T. 11 N., R. $49 E$.

\begin{tabular}{|c|c|c|}
\hline Coal U, base of Lebo member of & & \\
\hline Sandstone, light gray, shaly............ & 12 & \\
\hline Bone.. & 1 & \\
\hline andstone, light gray, shaly.... & 8 & \\
\hline 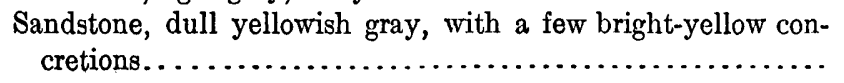 & 14 & \\
\hline 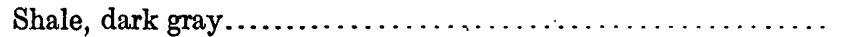 & 12 & \\
\hline Sandstone, yellow, fairly hard.... & 8 & \\
\hline Bone....................... & 1 & \\
\hline Shale, brown, carbonaceous... & 2 & \\
\hline Shale, gray.................... & 2 & \\
\hline Shale, brown, carbonaceous.. & 5 & \\
\hline Sandstone, yellowish gray.... & 2 & \\
\hline Sandstone, yellow, shaly........... & 4 & \\
\hline Sandstone, yellowish gray $\ldots \ldots \ldots \ldots \ldots \ldots \ldots \ldots \ldots \ldots \ldots \ldots$ & 14 & \\
\hline Strata covered by alluvium, to river... & 50 & \\
\hline & & \\
\hline
\end{tabular}

Composition.-In the coarser beds of the Lance, flakes of muscovite and biotite and fragments of quartz and kaolinized feldspar may often be detected with a hand lens. The one thin section examined was cut from a piece showing the sandy, grayish phase. Considerable quartz was revealed and a large amount of carbonaceous matter; the rest of the rock was chiefly a fine kaolinic material stained slightly brown.

No fossils were collected from the Lance in this district. Near Forsyth remains of Triceratops and other dinosaurs, regarded as index fossils of this formation, have been found. 


\section{STRUCTURE.}

The rocks in this district are for the most part nearly flat, though in few localities perfectly so. Measurement of the dips was made with the telescopic alidade in traversing the coal beds, and in this way angles of a quarter degree or less were accurately measured. As all the dips are small they are given on the map (Pl. XIII) in feet per thousand linear feet rather than in degrees; it may be borne in mind that a dip of $17 \frac{1}{2}$ feet per thousand is equivalent to $1^{\circ}$. Each dip given on the map was computed from three altitudes obtained on the same coal bed, generally within 2 miles of each other.

The general dip throughout the district is to the east and is steeper in the extreme eastern part of the area, where it is sufficient to carry coal beds $\mathrm{T}$ and $\mathrm{U}$ beneath the river. The extreme western portion, in R. $41 \mathrm{E}$., rises still more steeply on the eastern limb of a gentle anticline. Local dips as high as $5^{\circ}$ ( $87 \frac{1}{2}$ feet per thousand) are not uncommon, but the general rise is about $1^{\circ}$ (17 $\frac{1}{2}$ feet per thousand). Farther west, however, it increases, and the eastern part of the Bull Mountain field is on the western limb of this same anticline. In the center of the area under discussion the dip is invariably low, though very irregular, so that the strata seem to be undulated rather than corrugated. Measurements at several places on both sides of the Yellowstone-Missouri divide indicate that this ridge is slightly anticlinal, and Little Sheep Mountain appears to be the approximate summit of a very gentle dome. In like manner some of the creeks, notably Custer Creek, occupy synclinal valleys for a portion of their courses at least. Though such associations are rare in the older and more strongly contorted rocks, it is rather to be expected that the gentle folding of these formations would for a time control drainage, and their youth is such that apparently some of the streams are still mastered by the original slight inequalities of the old surface in which they started.

True faults are uncommon. One fault having a displacement of 3 feet and another with a displacement of 12 feet were noted, but faults like these are very rare. Slumping, however, is common in these soft and largely incoherent beds, and the coal, for example, is commonly hidden for considerable distances even in bare badland slopes where no vegetation obscures the outcrop.

Cross-bedding was referred to above under the description of the formations. It is most common in the Lebo member of the Fort Union, but occurs in places in the Lance and on a smaller scale in the yellow beds of the Fort Union. In figure 5 (p. 171) a lens of white tuffaceous sand is shown resting on an eroded surface of the underlying shale. Small erosional unconformities of this kind were observed at a number of places in the Lebo member, but slumping is 
so prevalent that in few other localities was.it possible to say definitely that a hiatus exists. If the Lebo member be really a fan, however, laid down by the ancient rivers from the region west of the Crazy Mountains, as suggested above, such irregularities in deposition would be expected. In like manner the conglomerate at or near the base of the yellow beds of the Fort Union at Sheridan Butte rested on an eroded surface. Continental deposition of this type, however, really implies the existence of such irregularities, and the hiatus represented is probably local and very small, much too small to warrant geologic recognition of the break.

\section{THE COAI.}

\section{PHYSICAL CHARACTER.}

The coals of this area seem to be on the boundary line between lignite and subbituminous coal, as they possess certain qualities which are generally considered peculiar to each of these classes. The coals of the yellow beds of the Fort Union exhibit something of the woody structure of typical lignite, but are black in color, whereas the lignites in the same beds farther from the mountains are brown. The coals of the Lebo shale member of the Fort Union, however, are generally compact and brittle, though a few specimens show woody structure. They are invariably black and generally exhibit a bright vitreous luster. This distinction between the coals of the two members of the Fort Union formation is not absolute, as the vitreous coal in some places occurs in the yellow beds and woody lignite is not uncommon in the Lebo member. The bulk of the coal is thus somewhat higher in grade than true lignite, and much of it possesses the physical characteristics of subbituminous coal. In this report it will therefore be referred to as "coal" rather than "lignite."

The beds of both formations contain bone and carbonaceous shale in large amounts as shown on Plates XI and XII, but this is especially true of the Lebo coal beds. Their commercial value is further impaired by the fact that all the coal is of poor stocking quality, disintegrating rapidly on exposure to the air.

Many of the beds are lenticular, but the persistence of some is surprising. Bed $\mathrm{H}$, for example, was traced over 18 miles, the length of the irregular outcrop itself being of course much greater. Bed U in the Lebo was traced for 40 miles, estimated in like manner. Moreover, just below the top of the Lebo a bed which does not reach 24 inches in thickness was examined in many different places, but whether this is really one bed or whether its apparent continuity is due to the occurrence of a number of small lenticular beds at about the same horizon is not known. As many of the more important beds have been actually traced for considerable distances, however, the 
writer is of the opinion that at least in this district many of the coal beds are more regular and constant then has been sometimes thought.

\section{CHEMICAL COMPOSITION.}

As nearly all the coal mining in the district is done in the autumn, there is no chance during the field season to obtain a sample from a fresh exposure. There is but one mine, located in sec. 9 , T. $12 \mathrm{~N}$., R. 51 E., and the entry to this has caved and the inner workings are inaccessible. No samples for analysis therefore were taken in the field. Those which might have been obtained from strip pits would have been nearly valueless as indices of the true character of the coal, owing to the weathering; which always affects it at the surface.

A. G. Leonard ${ }^{1}$ collected two samples from the region under consideration, both from T. 12 N., R. $45 \mathrm{E}$., on the north side of the divide, and therefore presumably from coal bed HH. He states that both were taken from the outcrop. Samples collected by Collier and Smith ${ }^{2}$ from mines in the adjacent Miles City field gave on analysis from 7,978 to 9,134 British thermal units in the air-dried material. The distinction between the coals of the yellow beds of the Western Union and those of the Zebo member given above, based on the physical characteristics, seems to be corroborated by chemical evidence. The textureless coal of vitreous luster is subbituminous, whereas the brown woody varieties may be classed as lignite.

\section{BURNING OF THE COAL BEDS.}

Many of the coal beds have become ignited at some time since the early Pleistocene, and in burning have baked and partly fused the overlying strata. The underlying strata are also generally somewhat affected, but in many places the coal has not burned entirely to the base of the bed, so that the underlying rocks are more or less protected. The burning thus usually bevels back the outcrop, progressing farthest back at the top of the bed. In general, where there is a cover of more than 10 or 20 feet the coal will not burn more than 50 or 75 feet back from the outcrop, although exceptionally the burning may extend farther. Where the cover is less than 10 feet the burning may extend throughout a large area. The effects produced depend entirely upon the quality and amount of the coal. Several thick beds, separated by 10 or 20 feet of rock, may produce very extensive results.

Aside from the strictly thermal effects of the burning coal the fact that in the course of its combustion it is largely dissipated

1 The coal fields of parts of Dawson, Rosebud, and Custer counties, Mont.: Bull. U.S. Geol. Survey No. 316. 1907, p. 205.

' Collier, A. J., and Smith, C. D., The Miles City coal field, Mont.: Bull. U. S. Geol. Survey No. 341, 1909 , p. 59. 
must be taken into account. The space previously occupied by the coal is taken up by the slumping of the overlying beds. When this occurs the beds have been baked hard and are commonly in a state of incipient fusion, so that in slumping down the large angular fragments have a tendency to cohere. This gives rise to a rock of which 30 or 40 per cent is air space, and it is chiefly through this rock that oxygen is supplied to the coal burning farther back. Vertical and perfectly stable cliffs of this hard natural brick contain many crevices large and long enough to allow the insertion of a man's arm. Where the coal is lenticular and not in great enough amount seriously to alter the overlying beds the latter slump down irregularly. The thin red bands of clinker and the white streaks of ash are then curiously contorted, resembling at a short distance the foliation of a highly crumpled gneiss. The outcrop of bed U, which is burning on Custer Creek, affords an excellent opportunity for the study of this clinkering process.

The rock produced is generally reddish in color, owing to the oxidation of the iron. Gray, green, yellow, and black varieties, however, are not uncommon, the lighter shades being caused presumably by the partial reduction of the iron. Magnetite is thus formed locally, and its influence on the compass needle has been noticed. The exact character of the clinker depends largely of course on the amount of heat to which it has been subjected. When slightly baked it is light red in color and retains its original texture. Higher degrees of heat produce a smooth material, resembling jasper, but commonly showing flow lines, flow brecciation, and other evidences of its origin. The highest heat produces a glassy vesicular slag which is generally black. Thin sections were prepared from two specimens of this clinker. One had been only slightly baked and retained to a great extent its original character. The other, which had undergone a higher heat, was largely reduced to a vesicular glass in which needles of colorless pyroxene had crystallized out. A surprising degree of heat and slowness of cooling is implied by this fact.

Coal outcrops were burning in four places in the area in 1911. In sec. 9, T. 11 N., R. 49 E., bed U was burning, and flames and live coals were revealed at a depth of 2 feet from the surface. Similar conditions existed for 200 feet along the outcrop of bed $\mathrm{NN}$ in sec. 9 , T. 11 N., R. 41 E. In sec. 8, T. 12 N., R. 41 E., the overlying beds had slumped over coal $\mathrm{NN}$, and smoke could be seen rising through cracks in the ground. In sec. 30, T. 12 N., R. 50 E., the heat of the coal burning beneath the surface could be felt and the peculiar sweaty odor distinguished. The combustion of these coals, which is common in the Dakotas, Wyoming, Montana, and Colorado, has been variously ascribed to spontaneous combustion due to the oxidation of the pyrite, to lightning, and to the agency of man. It is definitely known $60385^{\circ}-\mathrm{Bull.} 531-13-12$ 
that bed U in T. 11 N., R. 49 E., was ignited in 1909, two years prior to the writer's visit, by the camp fires of a round-up outfit, so that the burning may continue for a considerable time. The approximate age of the clinker itself may often be ascertained. Thus many of the older clinkers cap all of the buttes over a considerable region, and the assumption is that the burning took place in the old plateau before its dissection had produced these isolated buttes. This deduction is checked by the presence of a few waterworn pebbles of clinker in some of the stream gravel. It is probable that erosion has progressed far enough in some places to remove practically all the clinker fringe and again expose the coal. On the other hand, the comparative recency of some of the burning is indicated by the fact that it is confined to one side of a young and narrow valley.

\section{QUANTITY OF COAL.}

Under present economic conditions it is held that no bed of this grade of coal thinner than 30 inches is workable, although in the examination of this field all beds down to 24 inches were mapped, and many thinner beds were examined. On the basis of the data thus gathered the following estimates of the total tonnage in this field have been made: First, taking into account only beds 30 inches or more in thickness; second, considering all beds of a thickness greater than 14 inches. The latter estimate only slightly exceeds the former, which is explained by the fact that nearly all the coal in this field lies in thick beds along its northern border, so that most of the land back of the outcrop, as far as the northern limit of the field, is underlain by beds thicker than 30 inches.

The data available in making this estimate relate only to the character of the coal at the surface, as shown by sections measured on the outcrops. The assumption on which the estimate is based may be briefly stated as follows: If a bed is 40 inches thick at point $B$ and is only 30 inches thick at points $A$ and $C, 1$ mile on either side of $B$, and is known to decrease still further beyond these points, a circle is drawn with $B$ as the center and a radius of 1 mile, and all land within this circle and back of the outcrop is assumed to be underlain by workable coal, the average thickness of which is computed from the sections taken along the outcrop between points $\mathrm{A}$ and $\mathrm{C}$.

A bed of coal 1 foot thick contains approximately 1,800 tons to the acre. Of this 1,500 tons may be mined under favorable conditions, and under very poor conditions the minimum recovery will be 1,000 tons. The following estimate, however, is made on the hypothetic assumption that all the coal may be recovered.

The total tonnage on the 30 -inch basis is $1,189,833,380$ tons. The total tonnage on the 14 -inch basis is $1,409,557,900$ tons (about $16 \frac{2}{3}$ per cent more than the 30 -inch coal). 
The total tonnage of the coal in the yellow beds of the Fort Union formation in beds 30 inches or more in thickness is $1,028,516,260$ tons. If this quantity were all contained in one bed, of constant thickness throughout the area underlain by the yellow Fort Union strata, this hypothetical bed would be 14.8 inches thick. If all coals of a thickness greater than 14 inches are considered, the total tonnage would be $1,151,222,660$ tons, equivalent to a bed 16.7 inches thick.

The total tonnage of the coals of the Lebo member of the Fort Union formation, estimated on the 30 -inch basis, is $161,317,120$ tons, equivalent to a bed 2.7 inches thick. On the 14 -inch basis there are $258,325,240$ tons, equivalent to a bed 4.4 inches thick.

Estimated tonnage, by townships, of Fort Union coals in the Little Sheep Mountain field.

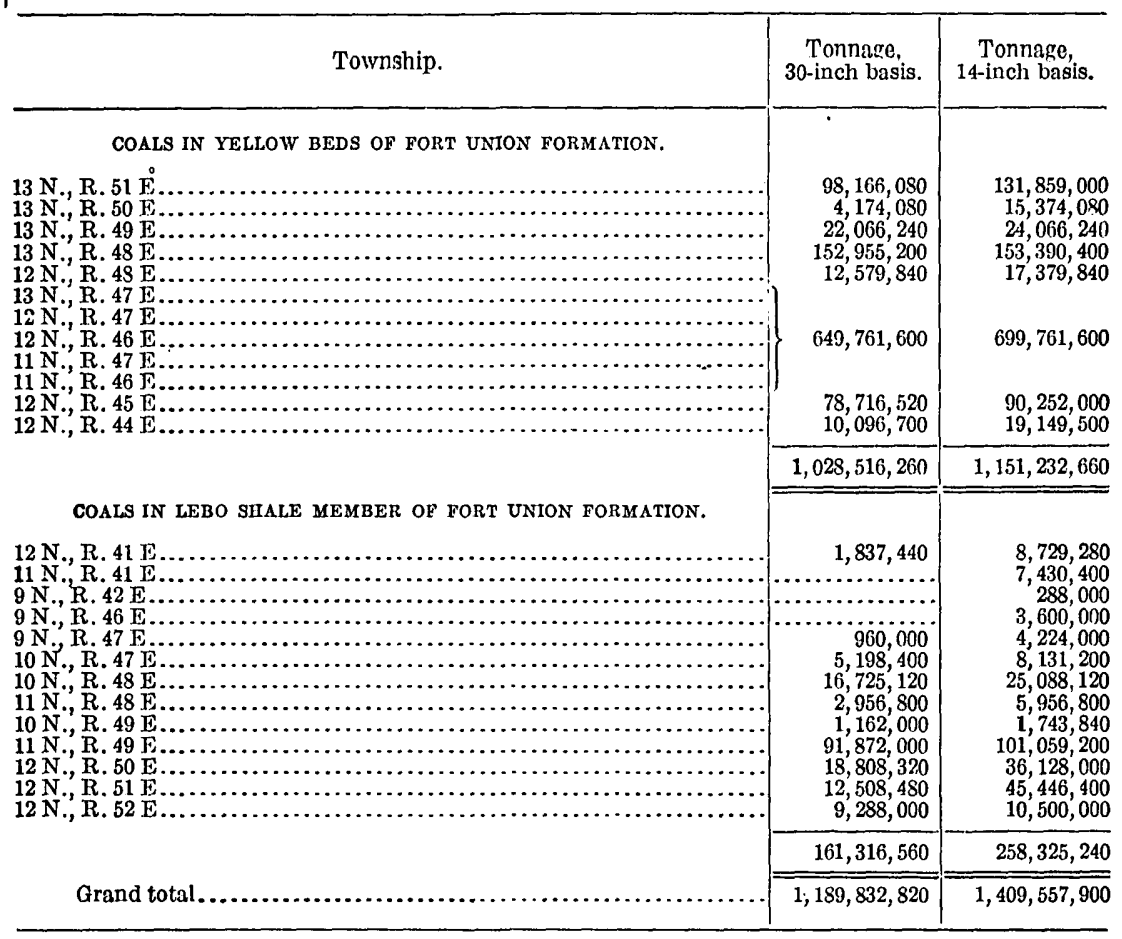

GENERAL CHARACTER OF THE BEDS.

COALS OF YELLOW BEDS OF FORT UNION FORMATION. ${ }^{1}$

The great bulk of the coal in this field occurs in the Fort Union strata above the Lebo member. As stated above, this coal is on the border line between subbituminous and. lignite; nearly all of it exhibits a woody structure, but is black in color. The beds are less lenticular than those of the Lebo member and some outcrops have

1 For location and extent of outcrop of these coals see PI. XIII, and for sections of them sce Pl. XI. 
been followed for considerable distances. Where the bed has been actually traced it has been assigned one letter throughout on the map; when it has been found to thin out, however, and another bed has been discovered some distance away within 8 or 10 feet of the horizon of the first, the second bed is assigned the same letter doubled. Thus HH indicates that this bed is either identical and continuous with $\mathrm{H}$, or that if not it is at practically the same horizon. The fact that a bed has been labeled $\mathrm{Y}$ indicates that it is probably below $\mathrm{X}$ and above $\mathrm{Z}$. Some of these correlations are certain, whereas others merely represent the best judgment of the writer upon a more or less obscure subject.

Bed A, the highest found in the district, is in many respects the best. Its outcrop in the district is not long, because the northern limit of the field is drawn arbitrarily, but in the southern part of $T$. 13 N., R. 47 E., it averages over 10 feet of black woody coal and is of about this thickness at the north boundary of the area. The outcrop of bed AA is burned in the district, but the thickness of the clinker implies a bed of considerable importance. It occurs only in two isolated areas in T. 12 N., R. 46 E., and so can not be definitely correlated, but it appears to be at about the horizon of bed A. Bed B caps several small hills east of Little Sheep Mountain; its outcrop is short and it contains only 3 or 4 feet of coal. Bed $\mathrm{C}$ is of economic importance for a short distance in T. 13 N., R. 47 E.; a parting which ranges in thickness from 7 inches to 43 inches separates the upper and lower benches, which average 3 and 5 feet of coal, respectively. Bed $D$ is not of great thickness and is very lenticular. It is mapped in several small areas south of Little Sheep Mountain and the outcrop was followed with considerable certainty to T. 12 N., R. 45 E. Bed E outcrops only in T. 13 N., R. 51 E. It commonly contains less than 18 inches of coal, but with the two larger beds below it, has given rise to a very thick clinker, which is one of the striking features of the topography in this region. It is somewhere near the horizon of bed $\mathrm{D}$ and may possibly represent that bed. Bed F is 3 to 5 feet thick in T. 13 N., Rs. 48 and 49 E., but some of it is dirty. Bed FF in T. 13 N., R. 51 E., is slightly better and is about at the same distance above bed $\mathrm{H}$. The difficulty in correlating these beds in T. $13 \mathrm{~N}$., however, is greatly increased by the fact that their outcrops in several places cross the north boundary of the district, and the correlation given for the beds in R. $51 \mathrm{E}$. is especially open to error on this account. Beds G and GG outcrop in the same localities and are of the same character as beds $\mathrm{F}$ and $\mathrm{FF}$. Beds $\mathrm{H}$ and $\mathrm{J}$ appear to be the most persistent of the upper coals, having been traced definitely from T. 13 N., R. 48 E., to T. 11 N., R. 46 E., and the former bed correlated with considerable certainty in T. 13 N., R. 51 E. Together they contain 2 to 8 feet of a tough woody coal, $J$ being commonly the 
thicker. The parting between the two ranges abruptly and irregularly from 2 to 20 feet. Bed HH, which outcrops on the north side of the divide in T. 12 N., R. $45 \mathrm{E}$., is certainly the stratigraphic equivalent of bed $\mathrm{H}$, and is probably the same bed. As the correlation of the bed in T. 13 N., R. $51 \mathrm{E}$., with bed $\mathrm{H}$ is not entirely certain, the former is also called HH. Bed K is only mapped in T. 13 N., R. 50 E., although it extends also into the townships on either side. Its economic importance is small, but it proved valuable in correlating some of the higher beds. Bed $\mathrm{L}$ is of local importance, being over 2 feet in thickness in only a few places. It underlies bed $\mathrm{J}$. in several places in $\mathrm{T}$. 12 N., R. 47 E.

\section{COALS OF LEBO SHALE MEMBER OF FORT UNION FORMATION. ${ }^{1}$}

The system of naming the several coal beds outlined above has been followed with regard to these beds also. The coal beds found in the Lebo member have been assigned letters from $\mathrm{NN}$ to $\mathrm{W}$.

The stratigraphic position of the bed marked NN is doubtful. It outcrops along the divide between Sunday Creek and the creek to the west in R. $41 \mathrm{E}$., where it is about 100 feet below the top of the Lebo shale. In character it strongly resembles the very persistent bed $U$, which is taken in the eastern part of the district to mark the base of the Lebo; but bed $U$ on Custer Creek is 340 feet below the top of that member. However, as the Lebo is irregular in thickness it is quite possible that it is only a hundred feet thick in R. $41 \mathrm{E}$. , in which case NN and $U$ would be identical. On the other hand, the strata underlying $\mathrm{NN}$ are dark and resemble Lebo rather than Lance, whereas there is a perceptible difference between those above and below bed $U$, and furthermore, as the material composing the Lebo is interpreted as having been washed from the region west of the Crazy Mountains it would not be expected that it would be so much thicker to the east than to the west, although this is possible. It seems more reasonable on the whole, therefore, to consider bed NN (and the immediately underlying bed $\mathrm{OO}$ ) as higher than $\mathrm{U}$; and the name assigned it is meant to indicate that its position is not definitely known, but that it is thought to be the highest of the Lebo coals.

Beds $\mathrm{P}$ and $\mathrm{Q}$ are of economic importance only in T. 12 N., R. $50 \mathrm{E}$. They are both lenticular and carry considerable bone, each averaging perhaps 3 feet of coal. Bed QQ reaches 2 feet in thickness in only one locality in T. 12 N., R. 49 E. Bed R outcrops in T. 11 N., R. 49 E.; it gives rise to a considerable clinker but is not a thick bed. Bed $\mathrm{S}$ is good in one locality in T. 12 N., R. 51 E., but its outcrop is of small extent. Bed $\mathrm{T}$ contains on the average about 3 feet of coal and is one of the more persistent beds of this member. Bed U, however, is

1 For location and extent of outcrop of these beds see PI. XIII, and for sections of them see PI. XII. 
the most persistent in the district. Its outcrop has been traced from T. 12 N., R. 52 E., where it crosses the Yellowstone, down to T. 9 N., R. 45 E., where it runs out of the district. East of Calypso it commonly contains more than 3 feet of coal; from that locality halfway to Custer Creek it consists merely of 10 or 15 feet of bone; in the valley of Custer Creek it contains 3 to 10 feet of coal; thence on to the place where it leaves the district it is variable in character but generally contains less than 2 feet of coal, although it is 20 or 30 feet in total thickness. In sec. 32 , T. 11 N., R. 49 E., it divides, and the lower member is called bed V; the distance between beds $U$ and $V$ varies, but in T. 10 N., R. 47 E., reaches 60 feet. Bed V is only locally of economic importance, being in most places chiefly bone and shale. In T. 12 N., R. 50 E., bed U divides again and the lower member has been called $\mathrm{W}$, a bed which is of small importance and which to the west is of negligible thickness. The distance between $\mathrm{U}$ and $\mathrm{W}$ is about 23 feet in sec. 31, T. 12 N., R. 50 E.

\section{DESCRIPTION BY TOWNSHIPS.}

The geology of the Little Sheep Mountain coal field having been discussed as a whole, the district will now be considered by separate townships. As a description of the formations and of the general character of the coal has already been given, this matter will not be repeated in the following pages. The topography and the geology of each township will be sketched in a general way, particular emphasis being laid on the location and character of the coal beds, the thickness of their cover, and any special peculiarities which may have been noticed concerning them.

On the map (Pl. XIII) to which constant reference will be made in the following pages, the sections taken on the several coal beds are numbered westward from T. 13 N., R. 51 E., along the outcrops of the upper beds, to T. 12 N., R. 41 E., and thence in a rough arc through the southern part of the district and up the river again toward Terry upon the Lebo coal beds. The townships will be described, therefore, in conformity with this order, starting with T. 13 N., R. 51 E., and finishing with T. 12 N., R. 52 E. The locations at which sections, were measured are marked on the map by numbers. The sections, correspondingly numbered, are shown on Plates XI and XII or are given in the text.

\section{T. 13 N., R. 51, E.}

Cedar Creek crosses the southwest corner of T. 13 N., R. 51 E., and a smaller creek traverses the whole township diagonally. The relief from the bed of Cedar Creek to the top of the divide to the northeast is about 525 feet. This divide is a remnant of the second of the old river terraces mentioned above and is covered with allu- 
vium. Below this alluvium the yellow beds of the Fort Union formation outcrop throughout the township, except for a narrow band of the Lance formation, which runs up Cedar Creek. The general dip is a little south of east and is low. In sec. 16 there is a distinct anticlinal fold, the east and west limbs dipping 23 and 14 feet in 1,000 , respectively.

The upper coal beds which outcrop in this township are E, FF, GG, $\mathrm{HH}$, and $\mathrm{K}$, their relations and thicknesses varying as follows:

Thickness and position of coal beds in T. 13 N., R. $51 \mathrm{E}$.

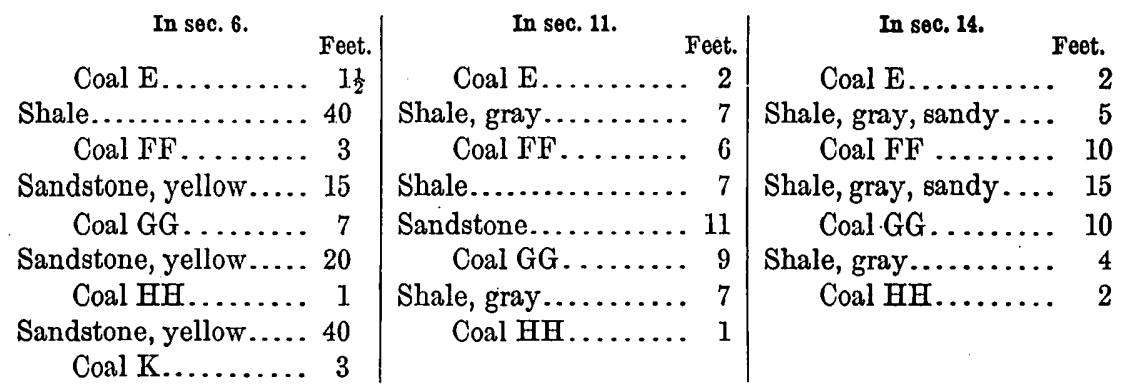

As shown by sections 2, 7, and 11, given below, bed $\mathrm{E}$ is of slight importance in the township. Beds FF and GG, however, are fairly thick beds. (See Pl. XI, sections 1, 3, 4, 6, 8, 9, 21, and 22; also 12 and 14 in the table below.) Bed GG is especially thick, containing in places as much as 4 feet of coal, separated by 2 feet of impure coal. Bed HH, as shown in sections 5 and 10 in the table below, is a bed of about the same importance as $\mathrm{E}$, and $\mathrm{K}$ does not contain as much as 2 feet of coal at any place examined. (See sections 13 and 1520, below.) The four highest of these coal beds outcrop along the edge of the old river terrace, which rises so steeply that the four beds appear on the map as one line. They lie under a cover more than 150 feet thick and are burned along most of the outcrop, so that only here and there in the younger coulees can sections be obtained. The two thick beds, FF and GG, have probably produced most of the clinker, but beds $\mathrm{E}$ and $\mathrm{HH}$ have also contributed, so that in places there is an apparently continuous mass of the clinker 80 feet thick. This clinker not only forms a heavy and now more or less dissected fringe along the outcrop but also caps all the high buttes to the southwest for a distance of 10 miles, so that it forms a striking scenic feature of this vicinity. In the stratigraphic section (fig. 3, p. 165) the relations of these coal beds and the character of the material which they have transformed into clinker are shown.

In the southwest corner of the township beds $\mathrm{T}$ and $\mathrm{U}$ are exposed and below bed $U$ the strata are mapped as Lance. Beds $T$ and $U$ outcrop near the bottom of the valley of Cedar Creek and are covered 
in most places by the slumping of the steep bank. They are burned at several points but not extensively, for bed $\mathrm{T}$ along the outcrop in this township contains barely 2 feet of coal and bed $U$ only slightly more. (See section 374, Pl. XII.) The stratigraphic distance between them is $16 \frac{1}{2}$ feet. The cover to the north is thin for about 2 miles, but the ground there begins to rise steeply. The general relation of these coal beds will be considered more fully below under the description of T. 12 N., R. 51 E.

Sections of coal beds in T. 13 N., R. 51 E.

[In addition to sections shown on Plates XI and XII.]

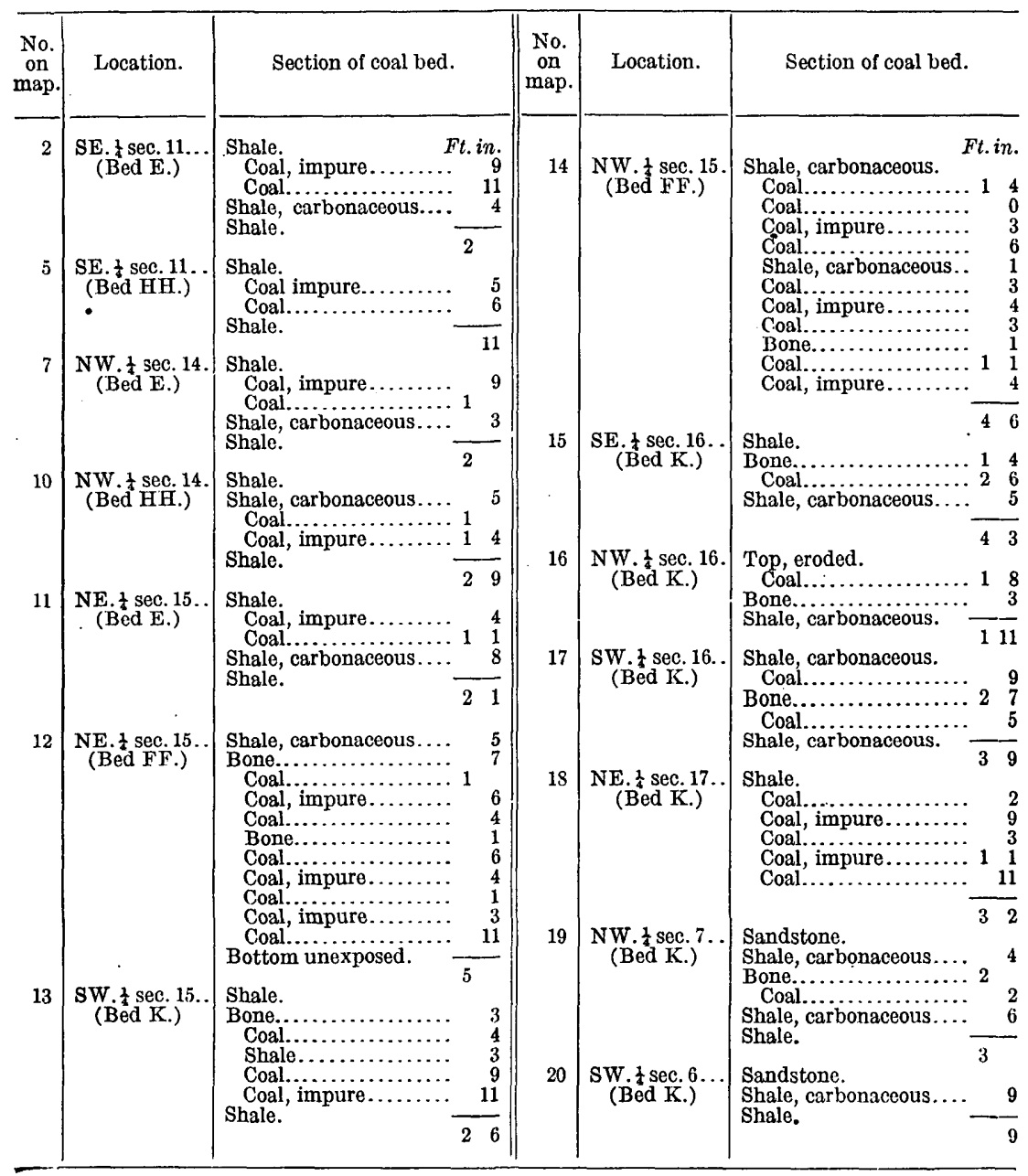




\section{T. 13 N., R. 50 E.}

Cherry Creek flows across the middle of T. 13 N., R. 50 E., in a general easterly direction, and Brackett Creek empties into it from the north. The township is thus roughly coincident with the basin formed by the confluence of these two streams. The yellow beds of the Fort Union formation outcrop over a large part of the township, but owing to the abrupt thickening of the Lebo shale member in this locality, as described above, the latter is brought to the surface in an irregular area whose approximate boundaries are indicated on the map. Extensive measurement of the dips was not made; a very gentle syncline was found, however, in sec. 8 , whereas in sec. 6 the strata seem to be horizontal.

The highest ground in the township is in the northwest and extreme northeast corners. In the northwest corner bed $K$ is of some importance, averaging slightly less than 2 feet of coal over the area mapped. (See sections 24, 25, 27, 28, 30, and 31 in $\mathrm{Pl}$. XI, and the sections given below.) About 40 tons have been taken from a strip pit in sec. 17 by the ranchers of the vicinity. As the outcrop runs around two low flat divides near their crests, its cover averages less than 40 feet and in places decreases to 10 feet. Bed $\mathrm{K}$ may be traced to the east into T. 13 N., R. 51 E., but as stated above it does not reach 2 feet in thickness, and it is valuable merely as a datum plane by which the higher coals may be correlated. To the west its economic importance decreases in a short distance, and the bed was mapped only a short distance west of this township. On the south side of the valley of Cherry Creek a bed at about the same horizon was found and examined, but proved to be almost entirely bone and shale. (See section 33, below.) In sec. 6, on the crest of the higher divide, bed $\mathrm{G}$ is present under only 15 or 20 feet of cover.

Sections of coal beds in T. 19 N., R. $50 \mathrm{E}$.

[In addition to sections shown on Pl. XI.]

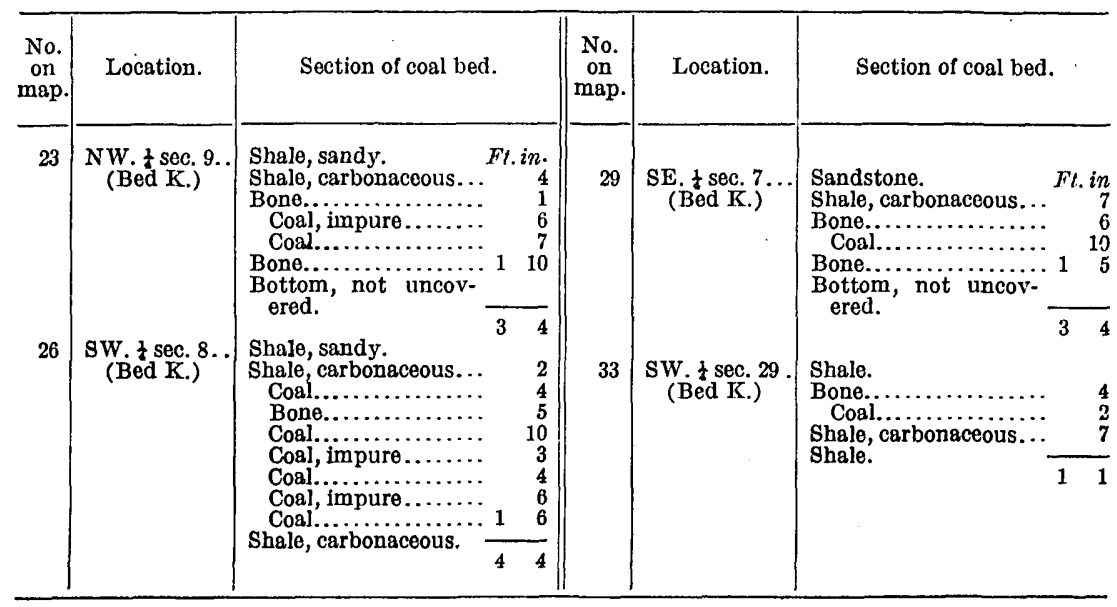


Beds $\mathrm{E}, \mathrm{FF}, \mathrm{GG}$, and $\mathrm{HH}$ are exposed for only a short distance in sec. 1 of this township. Their outcrops are burned and heavily clinkered, and no examination could be made.

The area of Lebo shale occurring in the township was examined for coal, but none was found. Two beds of bone and carbonaceous shale are exposed, but they are valueless.

\section{T. 13 N., R. 49 E.}

Cherry Creek, the extension of Cedar Creek, flows east across the middle of T. 13 N., R. 49 E. North of the stream the ground rises gently, but southward it is more broken and there are many buttes and chains of buttes which are capped with heavy clinker formed by the burning of the coal beds which outcrop along the northern border of the township. A good road follows the creek and renders the coalbearing area accessible. The dip is low; in sec. 2 it is southeast, in sec. 3 south, and in sec. 5 southwest. This area therefore appears to be on the northern edge of a very gentle synclinal basin.

As implied above, all the exposures of coal in this township are found in the two northernmost tiers of sections, where the outcrops of three beds, $\mathrm{F}, \mathrm{G}$, and $\mathrm{K}$, run in a general east-west direction. The stratigraphic distance between $F$ and $G$ in sec. 1 is 24 feet and between $G$ and $K 79$ feet. The lowest bed was mapped only in secs. 1 and 12, being elsewhere less than 24 inches thick. (See sections 34 and 35 below.) The distance between $F$ and $G$ is 46 feet in sec. 3 but only 15 feet in sec. 6 . These coal beds are of about the same thickness and are the same distance apart as beds FF and GG in T. 13 N., R. 51 E.; their burning has given rise to a clinker which may be followed eastward until it merges into that formed by the two last-mentioned beds; and they are the same distance above $\mathrm{K}$, which has been traced from T. 13 N., R. 51 E., to this township. It therefore seems reasonably certain that beds $\mathrm{F}$ and $\mathrm{G}$ are identical and continuous with beds FF and GG, respectively.

Bed $\mathrm{F}$ is variable in character and thickness but averages over 4 feet of coal, lenses and streaks of which are impure. (See sections $36,38,40,41,44,45,48$, PI. XI.) Bed G is nearly as thick, but a large portion of the coal is impure, and the value of the bed is further impaired by its numerous shale and bone partings, as shown in sections $32,37,39,42,43,46,47,49$ (PI. XI). Both beds are burned along most of their outcrop, which is further obscured by the gently rolling and grassy character of the country, so that complete sections on these beds are difficult to obtain. The outcrop is in general so near the border of the district that the cover is necessarily thin, especially over bed F, but the ground continues to rise to the north, and a cover of 100 feet is probably shortly attained. 
Sections on bed K in T. 13 N., R. 49 E.

\begin{tabular}{|c|c|c|c|c|}
\hline Location 34. & & & Location 35. & \\
\hline Sandstone................... & & & Sandstone..... & 6 \\
\hline Coal, impure................ & & 9 & Bone........ & 10 \\
\hline Coal, good......... & 1 & 9 & Coal.... & 2 \\
\hline Bottom not exposed. & & - & Bone.... & 9 \\
\hline & & 6 & Coal.. & 5 \\
\hline & & & Bone.. & 5 \\
\hline & & & $\begin{array}{l}\text { Coal............... } \\
\text { Shale. }\end{array}$ & 1 \\
\hline & & & & 4 \\
\hline
\end{tabular}

T. 13 N., R. 48 E.

Cherry Creek flows across T. 13 N., R. 48 E., entering in the northwest corner. The summit of Little Sheep Mountain rises in the township to the west, and the adjoining portions of this township rise to form the eastern slopes of the mountain. The land for the most part is rolling and grass covered, but is dissected locally by deep and narrow coulees, and the southern part of the area is also broken by many clinker-capped buttes. A good road follows Cherry Creek, and a poorer one branches from it at about the center of the township and runs southwest. The yellow beds of the Fort Union formation outcrop throughout the township; their dip is undulatory and very gentle.

Owing to the topography described above, the coal outcrops cross the northern border of the township to Cherry Creek and then trend south and east around the lower slopes of the mountain. Four coal beds, B, F, G, and $\mathrm{H}$ are exposed.

Stratigraphic position of coal beds in T. 13 N., R. 48 E.

Bed B (PI. XI, sections 54, 58).

Feet.

Shale and sandstone................................. 78

Bed F (Pl. XI, sections 50, 53, 55, 59).

Shale and sandstone $\ldots \ldots \ldots \ldots \ldots \ldots \ldots \ldots \ldots \ldots \ldots \ldots \ldots \ldots \ldots \ldots \ldots \ldots, 34$

Bed G (Pl. XI, sections 52, 56).

Shale and sandstone............................... 39

Bed H-J (Pl. XI, sections 51, 60, 62, 63, 66, 67, 68, 69).

The highest coal bed (B) is exposed only upon the most elevated points, where its outcrop is limited and its cover thin. It contains slightly more than 2 feet of coal. Bed F, as in T. 13 N., R. 49 E., is variable in quality but averages slightly less than 4 feet of coal. Its outcrop crosses the township line in sec. 6. Bed G is somewhat thicker than in the area to the east and carries generally in this township 6 or 7 feet of somewhat impure coal. In sec. 33, however, it is so thin as to be valueless and its outcrop was traced no further. Bed $\mathrm{H}$ becomes thicker than 24 inches rather abruptly in sec. 3, 
although there is a bed of carbonaceous shale at about this horizon in the two townships to the east. Bed $\mathrm{H}$ contains over 6 feet of good coal in sec. 17; to the south, in sec. 33 , it carries about 7 feet of largely impure coal; and in sec. 34 about 5 feet of similar material. In sec. 35 it divides and the lower member, which is about 3 feet thick, is called bed $J$. The distance between the two members reaches a maximum of 8 feet.

The cover of these beds is only locally thick, owing to the small amount of relief in the township. On many of the long fingers or narrow ridges around which the outcrops run (see PI. XIII) the cover is very thin, in some places less than 10 feet. The coal is burned and heavily clinkered along more than half of the outcrop, and the bed is generally concealed, so that sections were obtained with difficulty.

Beds $\mathrm{G}$ and $\mathrm{H}$ have been mined in the southwest corner of sec. 2 by the ranchers living in the neighborhood. About 50 tons had been removed from the open pit prior to 1911 . The coal is reported to burn well but to make a large amount of ash and to slack quickly on exposure.

Sections of coal beds in T. 13 N., R. 48 E.

[In addition to section shown on Pl. XI.]

\begin{tabular}{|c|c|c|c|c|c|}
\hline $\begin{array}{l}\text { No. } \\
\text { on } \\
\text { map. }\end{array}$ & Location. & Section of coal bed. & $\begin{array}{l}\text { No. } \\
\text { on } \\
\text { map. }\end{array}$ & Location. & Section of coal bed. \\
\hline 64 & $\begin{array}{l}\text { NE. } \frac{1}{2} \text { sec. } 19 . \\
(\text { Bed G. }\end{array}$ & 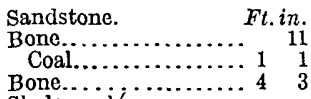 & 57 & $\begin{array}{c}\text { NW.t sec. } 9 . \\
\text { (Bed H.) }\end{array}$ & $\begin{array}{ccc}\text { Shale. } & F t . & \text { in. } \\
\text { Coal, dirty ........... } & 2_{8}^{8} \\
\text { Coal, good......... } 1 & 5+ \\
\text { Bottom concealed. }\end{array}$ \\
\hline 65 & $\begin{array}{l}\text { NE. } \frac{1}{t} \text { sec. } 33 . . \\
(\text { Bed G.) }\end{array}$ & $\begin{array}{l}\text { Shale. } \\
\text { Bone................. } 2 \quad 7 \\
\text { Shale. }\end{array}$ & & - & \\
\hline
\end{tabular}

T. 12 N., R. 48 E.

Custer Creek traverses the southern part of T. 12 N., R. 48 E., and the land in the northern part rises to form the divide between this stream and Cherry Creek. The surface is considerably broken, however, by many small valleys, and much of the topography is of the badland type. The yellow beds of the Fort Union formation cover the northwestern part of the township, but the Lebo shale member is exposed in the southeast corner. As already stated, typical badlands generally characterize the outcrop of the Lebo, so that the southeast part of the township is even more badly broken than the other parts. The township at present is uninhabited. Altitudes obtained along the coal outcrops indicate that the strata dip irregularly at low angles as shown on the map (Pl. XIII). 
LITTLE SHEEP MOUNTAIN COAL FIELD, MONT.

Sections of coal beds in T. 12 N., R. $48 \mathrm{E}$.

[In addition to sections shown on P1. XI.]

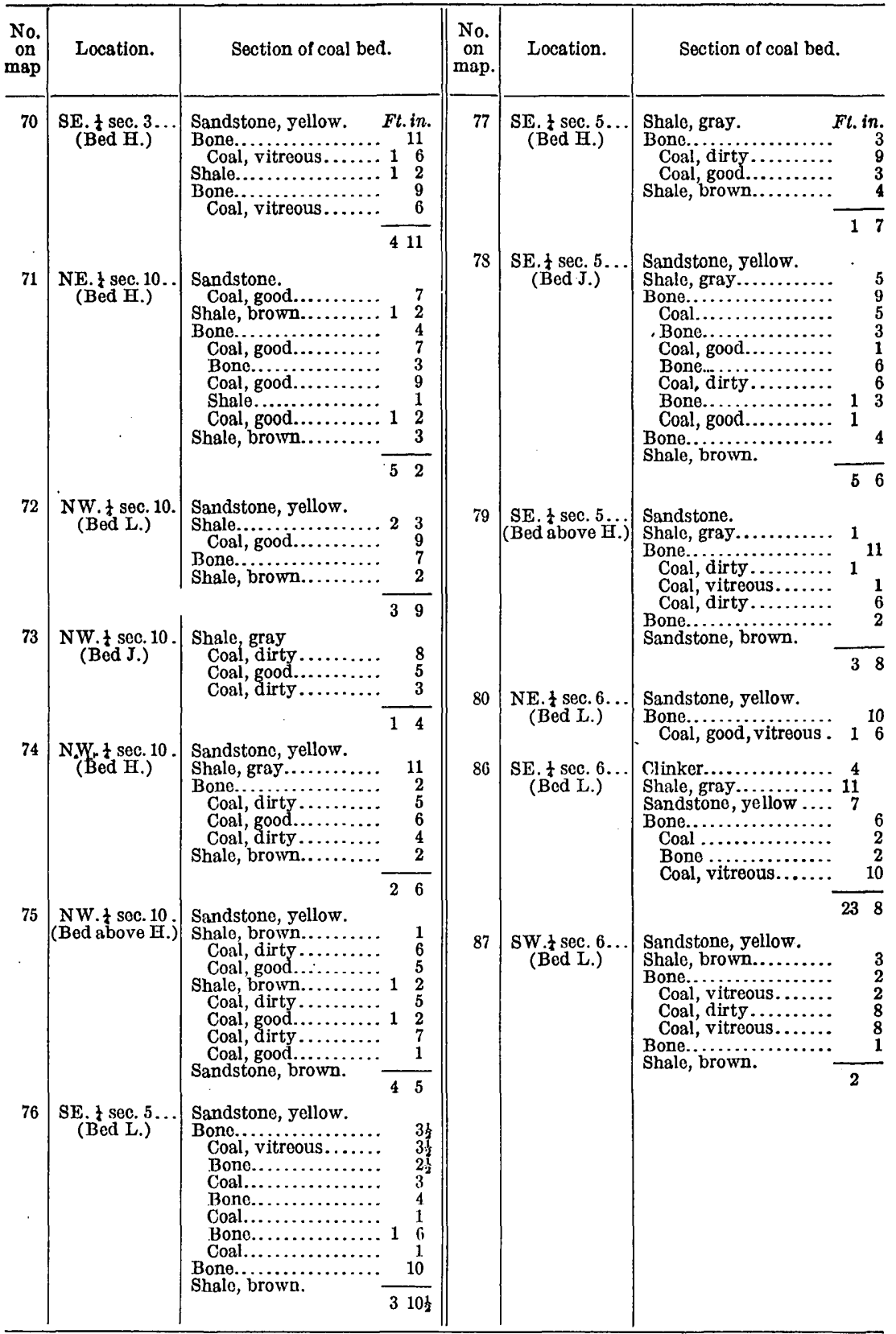

The coal outcrop runs in an irregular east-west direction along the south slope of the divide. Five beds of coal are exposed in this township-H, J, L, and two others not named. The distance between 
beds $\mathrm{H}$ and $\mathrm{J}$ in this township is 18 feet, and $\mathrm{L}$ is the same distance stratigraphically below $\mathrm{J}$. About 30 feet above bed $\mathrm{H}$ is a bed too thin to be of commercial value (sections 75 and 79, below), but which proved useful in correlating the underlying coals; and 7 feet below bed $\mathrm{L}$ is another bed which is of no economic importance (section 87, below). Bed $\mathrm{H}$ contains on the average more than 3 feet of coal, which is commonly of fairly good quality. Bed $J$, though of nearly the same thickness, is generally split by bone and shale partings and contains 2 feet of unbroken coal only locally. (See sections $83,84,85$, and $88, \mathrm{Pl}$. XI.) Bed L is of much the same character but is still thinner. The sections given below were taken on this bed, but its outcrop was not mapped. Of the five coal beds exposed in this township, therefore, $\mathrm{H}$ is the only one of commercial value.

Notwithstanding the poor quality of most of the coal, the beds, by a presumably synchronous burning, have given rise to a heavy clinker. The 20 or 30 foot cliff formed in this way has in most places protected the outcrop from erosion, so that the cover is at least of this thickness and is generally much thicker.

\section{T. 13 N., R. 47 E.}

The ridge known as Little Sheep Mountain runs northwest and southeast across T. 13 N., R. 47 E., so that the area includes all its highest slopes except the slope on the northwest. No large creeks traverse the township, but many deep and narrow coulees originate on the flanks of the mountain and much of the ground is thus badly broken. This is especially true of the southern and southeastern parts; the northeastern part of the township is chiefly a rolling and grass-covered country. In secs. 21,27 , and 28 a range of alluviumcovered hills at an altitude of about 3,200 feet constitutes a southeast extension of the main mountain ridge; a similar range of the same height runs along the northern boundary of the township. The altitude of Little Sheep Mountain is approximately 3,565 feet, which is the highest point of land on the Missouri-Yellowstone divide in the district described in this paper. Except for the terraces covered by alluvium, Fort Union rocks outcrop throughout the township, and in much of it they lie perfectly flat.

\section{Stratigraphic relation of coal beds in T. 13 N., R. $47 \mathrm{E}$.}

Shale and sandstone (to top of Little Sheep Mountain)........... 500

Coal A (Pl. XI, sections 91, 92, 101, 102, 103).

Shale and sandstone................................. 63

Coal C (Pl. XI, sections 93, 94, 98).

Shale and sandstone............................... $65 \pm$

Coal G (Pl. XI, section 61).

Shale and sandstone............................... $40 \pm$

Coal H (Pl. XI, sections 81, 1.66, 110).

Shale.

Coal J (Pl. XI, sections 82, lower bench of 106, 109, lower bench of 110). 
The coal, as shown on the map (Pl. XIII), outcrops around the east and south slopes of the mountain. In all, five beds are exposed in this township-A, C, G, H, and J. Bed A, the highest, contains 4 feet 7 inches of coal at one place in sec. 9 , but in sec. 15 it carries over 12 feet. In sec. 20 it is about 10 feet thick, and beyond this the outcrop is clinkered, so that no complete examination could be made. Bed C in sec. 9 is made up of two benches, separated by 3 feet of shale, the upper containing 2 feet of coal and the lower 5 feet, but in sec. 10 the parting is only 7 inches. In sec. 23 this bed contains less than 15 inches of coal, and its outcrop was not followed further. The outcrop of bed $\mathrm{G}$ in this township extends for only a short distance in two coulees; in the northernmost coulee it is less than 2 feet thick, but in the other it too thin to be of economic importance. (See section 99 below.). The outcrop of beds $\mathrm{H}$ and $\mathrm{J}$ enters the township from the south in coulees in secs. 31,32 , and 35 . Bed $H$ is about 3 feet thick and bed $J$ has a similar thickness; they are separated by 5 feet of shale. The stratigraphic distance between $\mathrm{A}$ and $\mathrm{H}$ is 168 feet.

The coal is burned along most of the outcrop, but the heads of the steeply graded coulees rising at the foot of the mountain have generally cut through the clinker and again exposed the coal. The cover of all the beds is heavy, attaining a maximum over bed A of 500 feet.

From the coulee in sec. 9, in which beds $A$ and $C$ are well exposed and under excellent cover, a good road might easily be built to sec. 1, which by the Cherry Creek road is about 35 miles from Terry. Sec. 15, in which bed A is 12 feet thick, is similarly accessible. This bed in sec. 28 is 16 feet thick (section 101, Pl. XI) and a road might be built from this locality either to the Cherry Creek road or southeast to join the road to Miles City. Timber is very scarce in this neighborhood.

Sections of coal beds in T. 13 N., R. 47 E.

[In addition to sections shown on Pl. XI.]

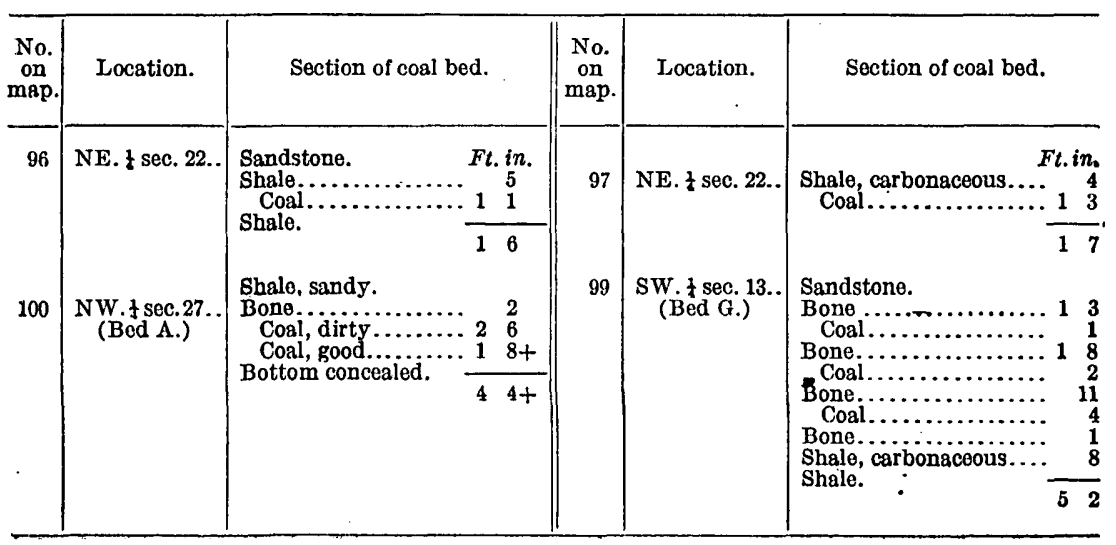


T. 12 N., R. 47 E.

Three branches of Custer Creek traverse T. 12 N., R. 47 E., in a southeasterly direction, merging in its eastern part to form the main stream. The surface is thus a succession of ridges which flatten out to the east. The yellow beds of the Fort Union formation outcrop throughout the township. The dips seem to indicate that a very gentle syncline crosses the northern part of the township from east to west.

The outcrop of the beds follows around the ridges and up the valleys mentioned above. Beds $\mathrm{D}, \mathrm{H}, \mathrm{J}$, and $\mathrm{L}$ are exposed in the township. Bed D does not contain so much as 15 inches of coal at any point, but beds $\mathrm{H}$ and $\mathrm{J}$ maintain thicknesses of 2 to 4 feet, respectively. (See sections $89,104,111,115,116,118,119, \mathrm{Pl}$. XI.) The distance between beds $\mathrm{H}$ and $J$ is 14 feet in sec. 18 . Bed L in sec. 1 is 14 feet below $\mathrm{J}$, and too thin to be of value, but in sec. 3 it contains about 4 feet of coal. In sec. 9 it is worthless, but farther up this valley in sec. 6 it contains $3 \frac{1}{2}$ feet of fair coal. (See sections 90, 105, 107, 112, 113, Pl. XI.) To the south, however, the bed is thinner and soon disappears.

The exposures are burned throughout the township, except at the heads of the youngest coulees. A very heavy clinker fringes the outcrops, and extends east for 8 or 10 miles as the cap rock of the higher buttes. The cover is in general thick, averaging over a hundred feet.

Sections of coal beds in T. 12 N., R. $47 E$.

[In addition to sections shown on Pl. XI.]

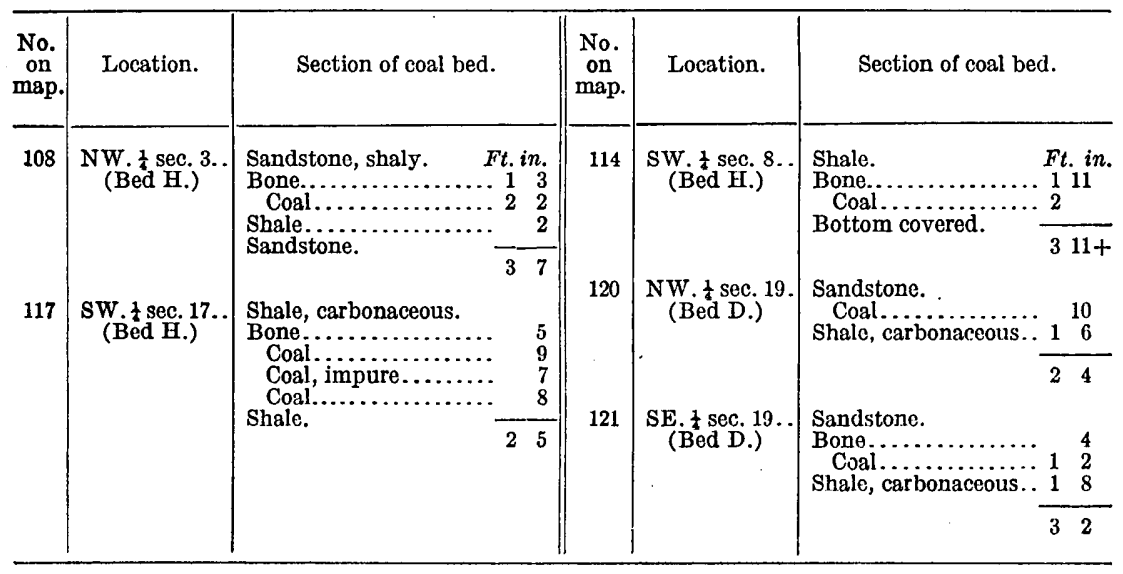

T. 11 N., R. 47 E.

The area contained in T. 11 N., R. 47 E., is drained almost entirely by Harris and Muster creeks, which flow across it to the southeast. The ground is for the most part gently rolling and grass covered, although it is locally broken by deep coulees and in a few places by 
clinker-capped buttes. The yellow beds of the Fort Union formation outcrop over most of the township, but the Lebo shale member is exposed just within its southern and eastern borders. The shale enters from the east in the valley of Harris Creek, and from the southwest in the valley of Muster Creek. The structure was studied only in the northwest corner of the township, where a northerly dip of 5 feet per thousand is fairly uniform.

The outcrop of the beds thicker than 24 inches is confined to the northwest corner of the township. Three beds are exposed, D, H, and J. Bed D (sections 135 and 138, PI. XI) is irregular in thickness and ranges from about $3 \frac{1}{2}$ feet of good coal to 3 feet of very impure material. Bed $\mathrm{H}$ is stratigraphically about 85 feet below $\mathrm{D}$. The distance between beds $\mathrm{H}$ and $\mathrm{J}$ is smaller in this township than in the surrounding area; it ranges from 2 to 20 feet and averages about 10 feet. Bed H contains from 1 to 2 feet of coal and bed $J$ from 1 to 3 feet. (See sections 134, 136, 137, 139, 140, Pl. XI.) An examination of the remainder of the township revealed the presence of but one bed. It reached a maximum thickness of 15 inches in sec.* 21 , and its outcrop was therefore not mapped.

The outcrops of the three upper beds are generally burned. The small distance between beds $\mathrm{H}$ and $\mathrm{J}$ causes their clinkers to coalesce, so that a mass of baked material 30 feet or more thick results. The cover over bed $\mathrm{D}$ averages less than 40 feet, but beds $\mathrm{H}$ and $J$ are covered to an average depth of over a hundred feet.

\section{T. 12 N., R. 46 E.}

The eastern part of T. 12 N., R. 46 E., is drained by Custer and Harris creeks and the western part by branches of Sunday Creek. Along the northern border is the Missouri-Yellowstone divide, and projecting southeast from this is a ridge separating the two drainage basins. In the northern part of the township, where the ground is most elevated, numerous buttes are capped by heavy clinkers. The yellow beds of the Fort Union formation are exposed throughout the township, and in sec. 34 they dip slightly to the southeast.

Four beds are exposed in this township-AA, D, H, and J. Bed $\mathrm{AA}$ forms a heavy clinker which caps portions of the central ridge, trending northwest to southeast through the township. In general, these areas are small, and probably the coal has been entirely burned, leaving a solid mass of clinker; the two areas mapped, however, are larger than the others and are known to contain coal. The outcrop on the map represents the inferred boundary of the unburned coal. In only one place was it possible to obtain even a partial section of this coal bed (section 125, below), but the thickness of the clinker indicates that the bed is probably important. Its exact correlation can not be determined, but from its approximate stratigraphic equiva$60385^{\circ}-$ Bull. 531-13-13 
lence to bed $A$, and from its inferred resemblance in thickness to this bed, it seems probable that beds $\mathrm{A}$ and $\mathrm{AA}$ are identical. About 60 feet above bed AA, at location 122, are traces of a still higher clinker, which caps the highest. hills in the township. The bed which must have given rise to this clinker is absent in the section so well exposed at Little Sheep Mountain, 7 miles to the northeast. Over the rest of the district discussed in this paper the land is lower and the bed, if once present, has been eroded. Ten feet below bed AA is a small bed on which sections 123 and 124 (see table below) were taken and which is everywhere thinner than 24 inches. The cover over bed AA is nowhere greater than 60 feet, and over much of the area mapped it is less than 20 feet.

Beds $\mathrm{D}, \mathrm{H}$, and $\mathrm{J}$ are exposed in the southeast corner of the township. The stratigraphic distance between beds $\mathrm{AA}$ and $\mathrm{D}$ is about 115 feet and between beds $\mathrm{D}$ and $\mathrm{H}$ about 100 feet. Bed $\mathrm{D}$ contains in general only slightly more than 24 inches of coal and in sec. 27 only 16 inches, so that its outcrop was mapped no further. (See sections $129,130,131,132,148,149, \mathrm{Pl}$. XI.) In sec. 20 it contains in all 26 inches of coal, but this is split by 12 inches of bone, and the bed at this point is worthless at the present time. Beds $\mathrm{H}$ and $\mathrm{J}$ are separated by 14 feet of shale. Bed $\mathrm{H}$ contains less than 2 feet of coal, and bed $\mathrm{J}$ about 4 feet. (See section 127, Pl. XI.) The cover of these beds averages over 150 feet, and that of bed $\mathrm{D}$ probably over 50 feet.

Sections of coal beds in T. 12 N., R. $46 E$.

[In addition to sections shown on Pl. XI.]

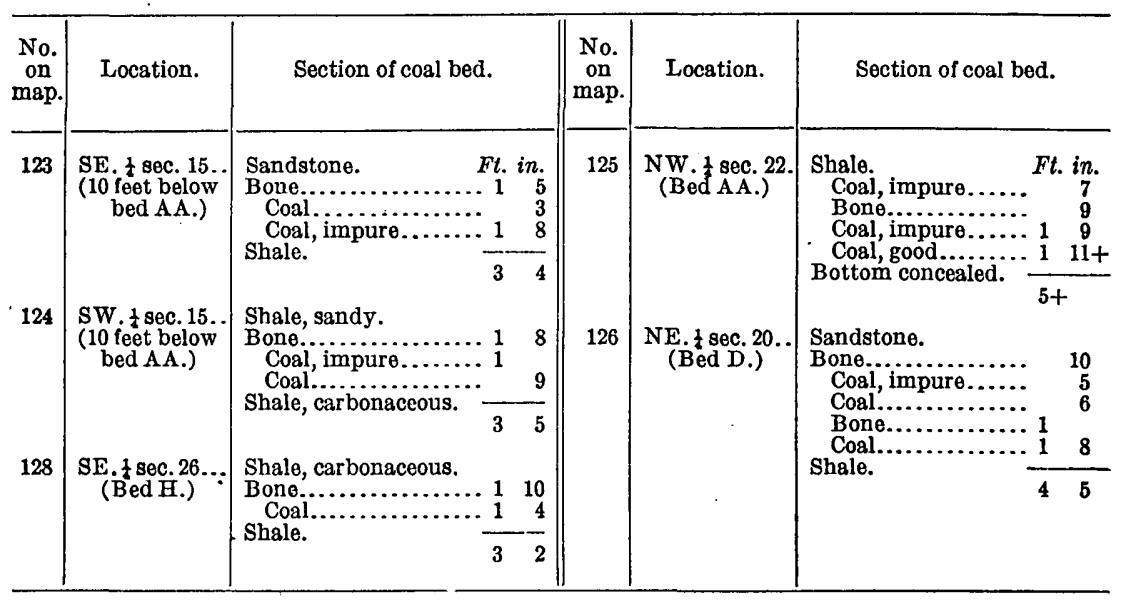

T. 11 N., R. 46 E.

The surface of T. 11 N., R. 46 E., slopes gently southward. A part of the area is drained by Sand Creek, but the greater part lies in the Sunday Creek drainage basin to the west. The relief is gentle, 
although the ground is somewhat broken locally by deep coulees and by several high clinker-capped buttes. The yellow beds of the Fort Union formation constitute the surface rock throughout the township, except in the southeast corner, where the Lebo shale member is exposed in the valley of Sand Creek. In sec. 1 the beds dip 3 feet in 1,000 to the north.

The outcrop of bed $\mathrm{D}$ runs in a general east-and-west direction along the northern border of the township. This bed is lenticular in character (see sections 142,144,145, 146,147, and 152, Pl. XI), but in general has a fairly constant 2 -foot layer of good coal at its base. In sec. 1 the bed contains more than 2 feet of coal for only a short distance, but in sec. 2 it reaches 3 feet in thickness and its outcrop was mapped from this point west to sec. 6 . Here it again becomes too thin to be of commercial value. Bed $H$ contains only about 2 feet of coal separated by about 1 foot of shale in sec. 1 , but bed J contains 4 feet of impure coal in this locality. (See sections 141 and 143, Pl. XI.) Except at this locality, however, and at a locality in sec. 5, where bed $\mathrm{H}$ contains 24 inches of coal, these beds are generally less than 18 inches thick. A bed which is about the stratigraphic equivalent of bed $\mathrm{L}$ was examined repeatedly in this township, but was found to be composed of bone and carbonaceous shale. The outcrops of beds $\mathrm{D}$, $H$, and $J$ are not burned in this township, except in places for short distances. The cover averages over 50 feet.

In sec. 36 , where the Lebo shale is exposed, a bed about 70 feet below the contact contains only 19 inches of coal.

Sections of coal beds in T. 11 N., R. 46 E.

[In addition to sections shown on PI. XI.]

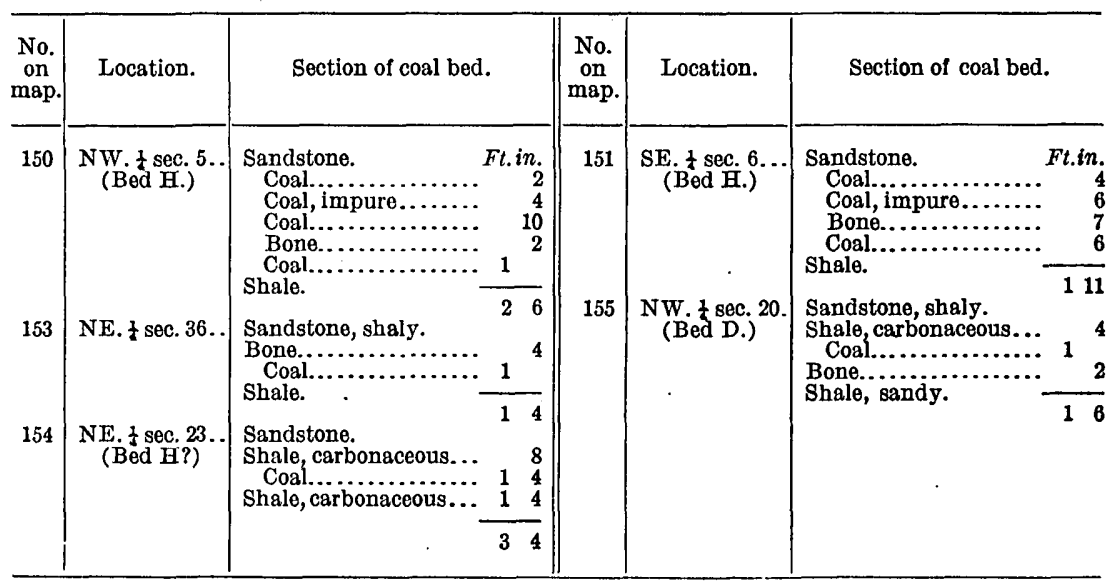




\section{T. 12 N., R. 45 E.}

The Missouri-Yellowstone divide crosses T. 12 N., R. 45 E., from sec. 19 to sec. 12 , so that the area is drained by tributaries of both streams. On the south slope of the divide the land is rolling and grass covered, with scarcely even a small cut bank to expose the strata. The crest of the divide is capped in places with a heavy clinker, and on the north side the ground is badly broken by many very deep and abrupt coulees and by clinker hills. The yellow strata of the Fort Union formation are exposed throughout the township. Altitudes determined along the coal outcrops indicate the presence of a gentle dome whose summit is located on the crest of the divide and about at the center of the township.

Two beds, $\mathrm{D}$ and $\mathrm{HH}$, are exposed in this township and on the crest of the divide there are traces of a heavy clinker at approximately the same level as coals A and AA, which outcrop in Little Sheep Mountain and which are at the same distance (about 175 feet) above bed $H$. It seems probable, therefore, that this clinker is the result of the burning of beds $\mathrm{A}$ and $\mathrm{AA}$, which are thought to be identical. Bed D, as exposed in sec. 19, contains over 3 feet of coal, and its inferred outcrop was mapped east to sec. 28 , where the bed is again exposed. At this point (see sections 172 and $173, \mathrm{Pl} . \mathrm{XI}$ ) it contains practically no pure coal, and it is, moreover, too thin to be of value. Its outcrop was followed southeast into T. 11 N., R. 46 E., but the bed in this township is not sufficiently thick to warrant mapping. Bed D is also exposed on the north side of the divide, where it was mapped in secs. 4,5 , and 9 ; in this area it carries 2 to 3 feet of coal, and elsewhere is even thinner. (See sections 164 and 165, Pl. XI.)

Bed $\mathrm{HH}$, on the north side of the divide, is fairly thick, containing in the western part of the township a maximum of 8 feet of coal. In sec. 18 it is stratigraphically about 115 feet below bed $D$. To the east its thickness is less, and in sec. 1 it carries only about 3 feet of coal. (See sections 157, 158, 159, 168, and 169, Pl. XI.) As shown on the map, it is exposed in this township only in the deep coulees which dissect the north side of the divide. Its outcrop, except at the head of these ravines, is generally burned. In several coulees, notably in the westernmost, considerable stripping has been done by the ranchers of the vicinity. Two analyses of this coal on samples taken from one of these coulees are given by A. G. Leonard. ${ }^{1}$ On the south side of the divide this bed is apparently represented only by a thin bed of bone and carbonaceous shale. (See section 174, Pl. XI.)

The altitude of the top of the divide in this township is about 3,130 feet, and bed HH is therefore under nearly 200 feet of cover. As it

1 The coa] flelds of parts of Dawson, Rosebud, and Custer counties, Mont.: Bull. U. S. Geol. Survey No. 316, 1907, p. 205. 
outcrops only in the deep coulees, the bed is covered just back of the outcrop to a depth of 30 feet of more. This locality is about 45 miles from Miles City by the present roads, and there is no timber of any kind within a radius of 18 miles.

Sections of coal beds in T. 12 N., R. $45 \mathrm{E}$.

[In addition to sections shown on Pl. XI.]

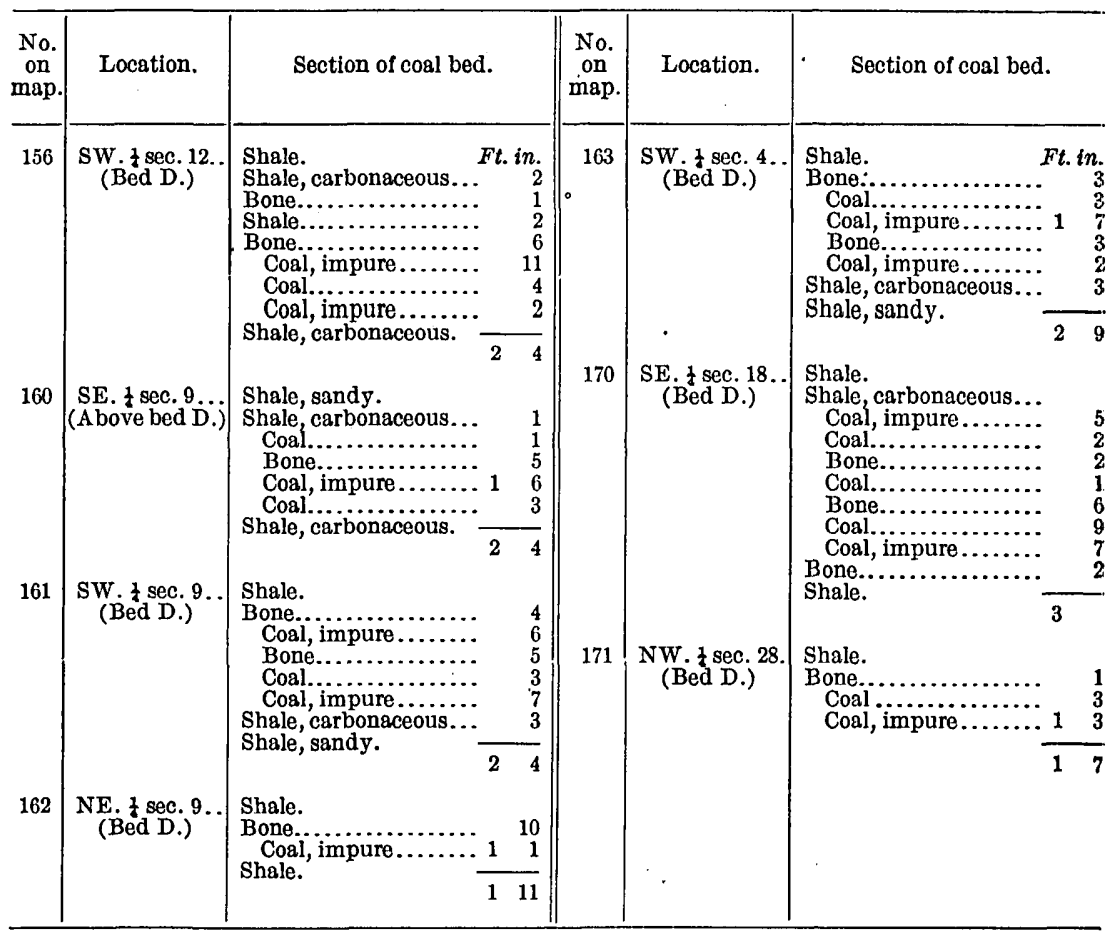

T. 11 N., R. 45 E.

Two branches of North Sunday Creek drain T. 11 N., R. 45 E. The relief is low and the area is characterized by gently rolling prairies. Even the larger creeks in few places cut sharp valleys, so that rock exposures are very rare. The yellow beds of the Fort Union formation constitute the surface rock throughout the township, but no determinations of the structure could be made.

No coal is exposed in this township. As rock exposures are rare, the outcrop of a small bed might not be detected, but if coal of economic importance were present it would very probably be exposed at some place or its presence be revealed by burned rocks. Moreover, only the basal yellow beds of the Fort Union formation are exposed in this township, and this horizon is elsewhere barren of coal. It is fairly certain, therefore, that no coal bed of commercial value outcrops in this township. 


\section{T. 12 N., R. 44 E.}

The Missouri-Yellowstone divide crosses the northeast corner of T. 12 N., R. 44 E., and most of the streams flow toward the south into Sunday Creek. On this side of the divide the ground is corrugated by the long and gentle north-south ridges which separate the southward-flowing streams, but north of the divide the country is broken by deep coulees and clinker hills. The Jordan stage road from Miles City crosses the township. The yellow beds of the Fort Union formation outcrop throughout the township, dipping about 1 foot per thousand to the west.

Beds $\mathrm{D}$ and $\mathrm{H}$ are exposed in this township. The higher portions of the divide are capped by a heavy clinker which can not be definitely correlated, but its thickness and stratigraphic position indicate a probable derivation from beds A and AA. Bed D, the outcrop of which extends across from T. 12 N., R. 45 E., was followed largely by its clinker from sec. 24 to sec. 8 . (See Pl. XIII.) At the point where it enters this township, bed D probably contains about 3 feet of coal. No exposure was found except in sec. 8, where the bed was examined in a well at a depth of 14 feet and was found to be of little or no value. (See section 175, Pl.XI.) From the comparative thickness of the clinker at several places, notably in sec. 22 , this lenticular bed may locally contain as much as 4 or 5 feet of coal, but it was not possible to make any direct observations upon it. Bed D is also exposed on the north side of the divide but it is less than 24 inches in thickness.

Bed $\mathrm{H}$ outcrops on the north side of the divide, but in this township it is continuously burned except in sec. 12. At this location, at the head of a deep coulee, the bed contains $8 \frac{1}{2}$ feet of coal. (See sections 166 and $167, \mathrm{Pl}$. XI.) Its immediate cover is 40 feet but less than a mile back from the outcrop the cover is over 200 feet. The sides of this coulee, which extends into T. 12 N., R. 45 E., have been stripped for a quarter of a mile by the ranchers of the vicinity and several hundred tons of coal have been removed. The coal burns well, does not leave an excessive amount of ash, and does not slack readily unless too finely broken. It is the chief source of fuel of most of the ranchers living within 15 miles.

\section{T. 11 N., R. 44 E.}

The northern part of T. 11 N., R. 44 E., is gently rolling prairie land, underlain by the yellow beds of the Fort Union formation. In the southern part, however, the Lebo shale member outcrops in the valley of Norih Sunday Creek (see Pl. XIII), and exerts its characteristic influence on the topography. The valley of North Sunday Creek is broad and fairly flat, but it is bordered by a narrow zone of badlands strikingly different from the rolling prairie to the north. 
No coal of a thickness greater than 24 inches outcrops in this township. Much of the area is underlain by the lower part of the yellow beds of the Fort Union and these are not known to carry coal at any locality in the field. Forty or fifty feet below the top of the Lebo member there is a small bed, chiefly of bone and carbonaceous shale, which contains less than 6 inches of coal. .

\section{T. 12 N., R. 43 E.}

North Sunday Creek, which rises in T. 12 N., R. 43 E., is so large and vigorous that it has crowded back the Missouri-Yellowstone divide into the township to the north. Like most of the country on the south side of the divide, the surface of this township is gently rolling and grass covered, and rock exposures are practically absent. The yellow beds of the Fort Union formation constitute the surface rock throughout the township, but no exact observations on their structure could be made.

The outcrop of coal bed D was followed west from T. 12 N., R. 44 E., nearly across this township. The bed is covered, and its outcrop could be traced only by few small areas of clinker and by prairie dog burrowings. Pits were dug in two places where these animals had brought coal to the surface, and the bed was reached at 4 or 5 feet. In neither place did it contain more than 15 inches of coal, which was, moreover, very impure. A higher clinker caps some of the most elevated points in the township, but no coal remains.

Sections of coal bed in T. 12 N., R. $49 \mathrm{~W}$.

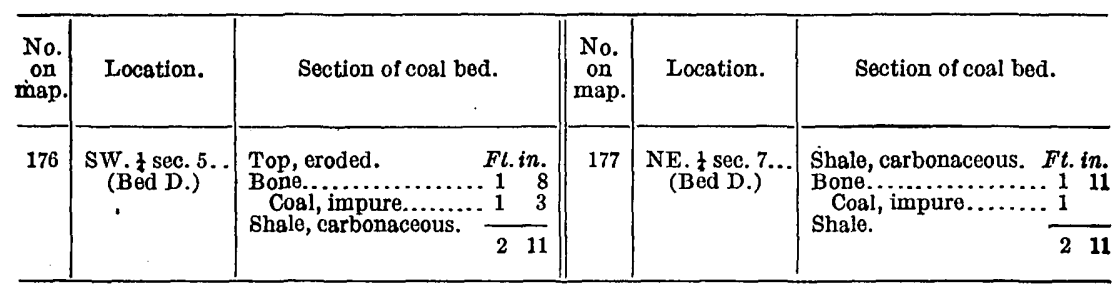

T. 11 N., R. 43 E.

The yellow beds of the Fort Union formation outcrop in the northern part T. 11 N., R. $43 \mathrm{E}$. The country is rolling and grass covered, though some of the ridges are fairly steep. In the southwestern part of the township the Lebo shale member is exposed, and its appearance at the surface is attended by the usual formation of badlands. Exact observations on the structure were not made in this township. In the northern part of the area, which is underlain by the lower part of the yellow beds of the Fort Union, no coal is exposed. In the southern part of the township a bed outcrops about 50 feet below the top of the Lebo shale member. It does not contain 
more than 15 inches of coal at any place examined. The following section is typical:

Section of coal bed at location 178, in the SE. $\frac{1}{4}$ sec. 27, T. 11 N., R. $43 E$.

Shale, carbonaceous.

Ft. in

Coal, impure

10

Bone.

Shale, carbonaceous.

T. 12 N., R. 42 E.

The Missouri-Yellowstone divide traverses T. 12 N., R. 42 E., in a southwesterly direction from sec. 3 to sec. 19. In the southern and eastern parts of the township the relief is low and the ground is gently rolling, but many deep coulees originate on the north flank of the divide and thoroughly dissect the northwest corner of the township. The yellow beds of the Fort Union formation constitute most of the surface rock; the Lebo shale member outcrops in sec. 6 and also just within the south boundary of sec. 31 . No measurements on the structure were made in this township, but from dips recorded in T. 12 N., R. 41 E., it seems probable that the strata dip to the east

On the southern slope of the divide no coal is exposed, nor are there any indications of a hidden outcrop. In the northwest corner of the township, however, two beds outcrop in the deep coulees which dissect this region. The upper, which may correspond to bed $D$, contains merely 23 inches of bone and 10 inches of carbonaceous shale. (See section 179 below.) Sections 180 and 181, on the lower coal bed, which may correspond to bed $\mathrm{H}$, indicate a slightly better bed, but one which is nevertheless too thin to be of value.

Sections 181 and $181 a$ in the following table, taken 30 feet apart on the lower bed, illustrate its lenticularity, a character which it has in common with many of the coals of the yellow beds of the Fort Union formation:

Sections of coal beds in T. 12 N., R. $42 E$.

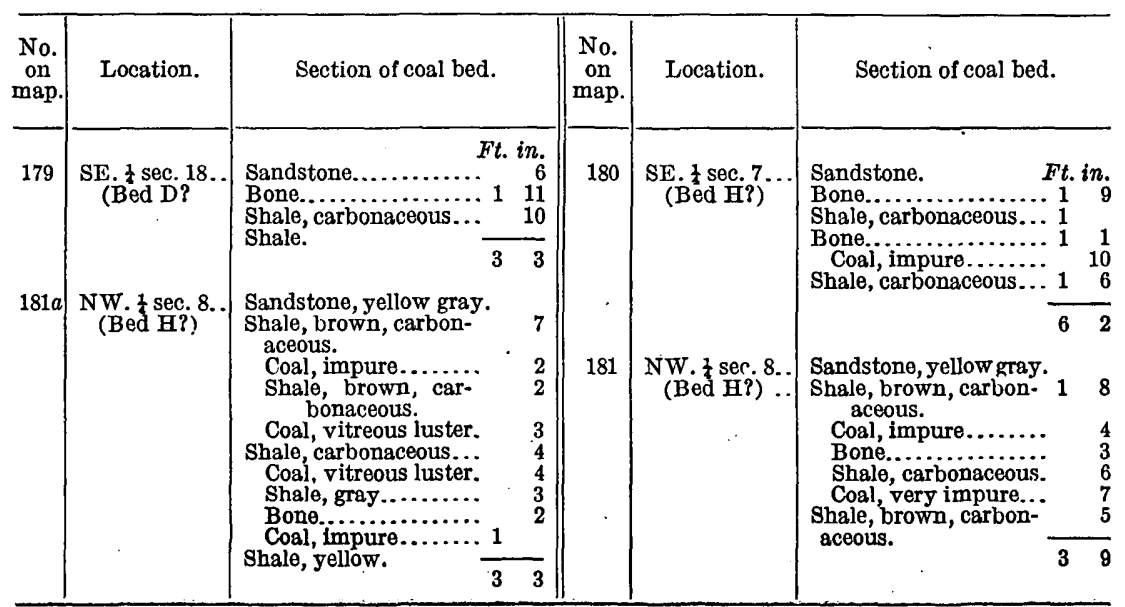




\section{- T. 11 N., R. 42 E.}

The upper course of South Sunday Creek traverses T. 11 N., R. 42 E., in a southeasterly direction. The boundary between the yellow beds of the Fort Union formation and the Lebo shale member is roughly parallel to this stream and is a short distance northeast of it. North of the creek the ground is a rolling prairie, but to the southwest in the country underlain by the Lebo shale member a badland area is present. No measurement of the dip of the rocks was made in this township. From the unusually strong easterly dip in T. 12 N., R. 41 E., however, and from the fact that no yellow beds of the Fort Union remain southwest of the creek in this township it is probable that the strata dip to the east. Chiefly because of this dip the Lebo shale member outcrops much nearer the divide in this township than it does in the areas to the east.

An examination of every section in this township failed to reveal any coal. The lower part of the yellow beds of the Fort Union are not known to contain coal at any locality in this district, and in the upper beds of the Lebo shale no coal of a thickness greater than 24 inches is known to exist.

\section{T. 12 N., R. 41 E.}

The Missouri-Yellowstone divide enters T. 12 N., R. 41 E., in sec. 24 , runs northwest to sec. 4 , and then southwest to sec. 18 , where it crosses the west line of the township. The divide between the Sunday Creek drainage basin and the basin to the west runs south from sec. 18. The yellow beds of the Fort Union formation outcrop only in the eastern part of the township (see Pl. XIII), the eastern dip carrying the Lebo shale member to the surface in this township even at the crest of the divide. The divide is lower in this township than it is farther east, owing, doubtless, to the softness of the shale which forms it. The land in the eastern part of the township is rolling and grass-covered, but the portion underlain by the Lebo is chiefly of the badland type. The valley of Sunday Creek is fairly flat and broad, but a strip of badlands between it and the contact with the yellow beds of the Fort Union is in many places nearly impassable.

Two coal beds outcrop in this township-beds NN and OO. The outcrop of these beds enters the township in sec. 5 and runs south. across the divide and into the head coulees of Sunday Creek. The beds dip a little more than $1^{\circ} \mathrm{NE}$. in sec. 5 , east in sec. 17 on the crest of the divide, and southeast in sec. 20. The divide thus appears to be anticlinal at this place. A sharper southeasterly dip in sec. 16 causes the outcrop to cross the Sunday Creek divide into the drainage basin of Porcupine Creek. Throughout this distance it is covered, but the beds may be traced by the faint pinkish tinge which their old and now almost eroded clinker imparts locally to the soil. Bed 
NN contains only 11 inches of coal in sec. 5 , but in sec. 7 it carries a total of about 4 feet, split by many partings, however, the bed having a total thickness of 10 feet. (See sections 188, 190, and 191, Pl. XII.) A bed which may be NN at location 182 consists entirely of shale and bone. In sec. 17 it is 22 feet thick, of which only 8 feet is largely coal, the remainder being bone and shale. In sec. 30 it contains no coal and none was found farther to the southwest in this township. At location 191 the bed dips $5^{\circ}$ N., $20^{\circ}$ E., and local dips as high as $14^{\circ}$ in that direction were observed. Bed 00 was not found to contain as much as 12 inches of good coal in this township. The stratigraphic distance between beds $\mathrm{NN}$ and $\mathrm{OO}$ is 47 feet. A small bed 3 to 10 feet below NN at no place contains more than 12 inches of coal.

Sections of coal beds in T. 12 N., R. $41 E$.

[In addition to sections shown on Pl. XII.].

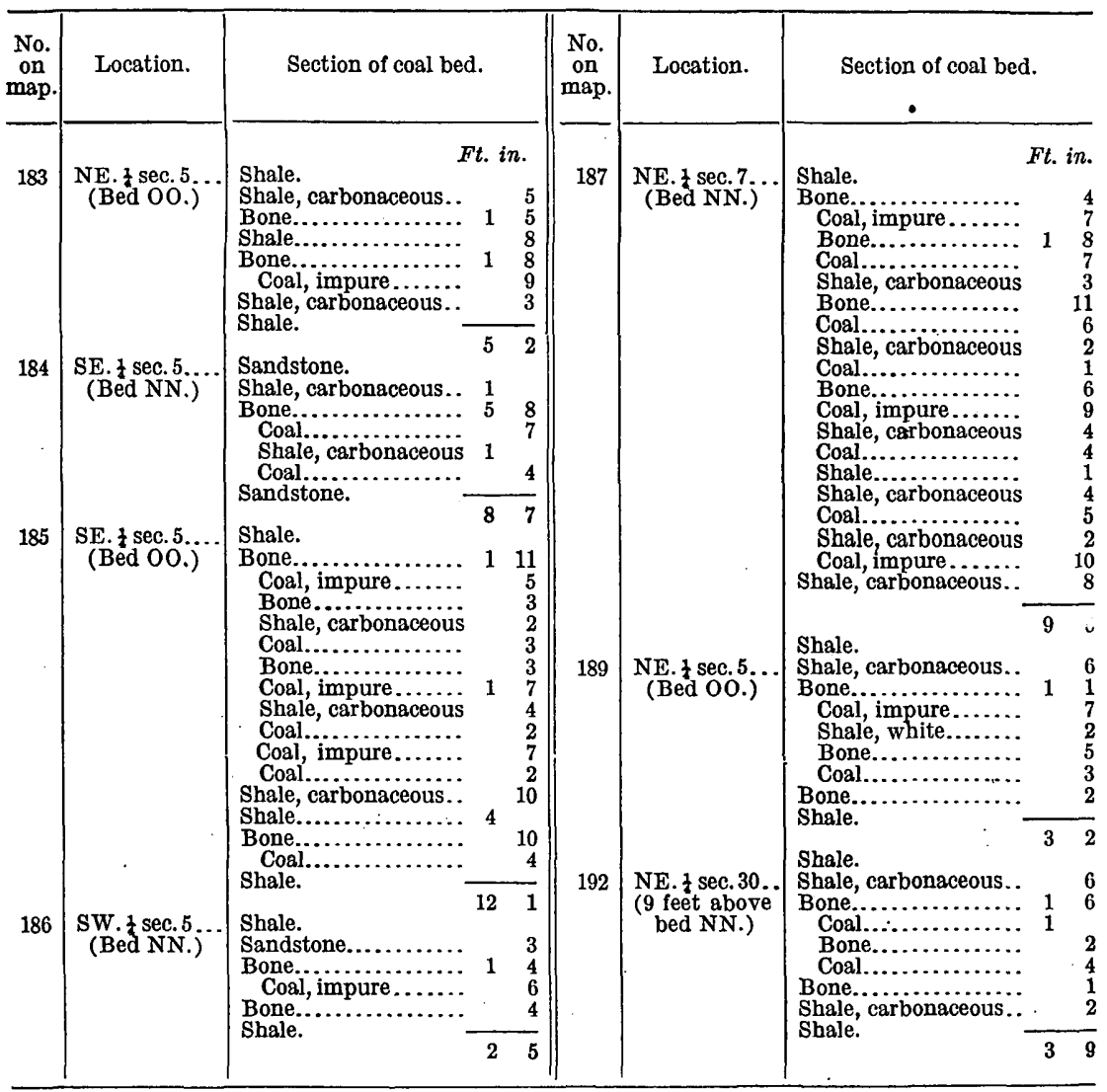


The stratigraphic position of these beds with reference to the other coals of the Lebo is doubtful. Bed NN in character and thickness resembles bed $U$, which marks the base of this member, but bed NN is only about 100 feet below its top. Moreover, the strata below this bed resemble Lebo rather than Lance; so that, although it is possible that the Lebo shale is only 100 feet thick in this locality, it seems more probable that this coal is not bed $U$, the base of the Lebo, but a considerably higher bed. The.name assigned it indicates that it is probably the highest Lebo coal, but that its position in the formation is doubtful. The bed has been traced south to T. 9 N., R. 42 E., where it passes out of the district, but at no other point does it contain more than 24 inches of coal in one bench.

T. 11 N., R. 41 E.

The divide between Sunday Creek and the creek lying to the west trends north and south through T. 11 N., R. 41 F. Except for the valley of Sunday Creek, which is fairly broad and flat, the topography is largely of the badland type. The rock exposed in the eastern part is the Lebo shale member, and though it is possible that the Lance formation underlies the western portion, it is believed (see p. 13) that the Lebo shale constitutes the surface rock throughout the township. The dip in sec. 4 is $2 \frac{1}{2}^{\circ} \mathrm{N}$. $70^{\circ} \mathrm{E}$., or 44 feet in 1,000 .

Bed NN is exposed on the west side of the divide which traverses the township and the approximate location of its outcrop is given on the map (Pl. XIII). The land slopes gently on the east flank of the divide and the dip of the bed is sufficient to prevent its outcropping on this side. At location 199, in the NW. $\frac{1}{4}$ sec. 22 , the bed carries 3 feet of impure coal, but less than half a mile away it contains less than 14 inches (section 198, Pl. XII). At no other place in the township does the bed contain 24 inches of coal, although the total thickness of carbonaceous matter in many places is 12 feet or more. (See sections below.) There is generally a streak of bone near the top ranging in thickness from 1 to 10 feet, and below this an interbedding of carbonaceous shale, bone, and coal in 1 or 2 inch bands. The bed in many places is clinkered and in sec. 9 the outcrop for a distance of 200 feet was burning in 1911. At a stratigraphic distance of about 50 feet below this bed is another which probably corresponds to bed $0 O$. At locations 195 and 197 in sec. 17 it contains about $3 \frac{1}{2}$ feet of coal, but all more or less impure, occurring moreover in six different streaks separated by 2 or 3 inch partings of bone and shale. It is therefore held to be worthless, at least at the present time, and its outcrop was not traversed. 
Sections of coal beds in T. 11 N., R. $41 E$.

[In addition to sections shown on Pl. XII.]

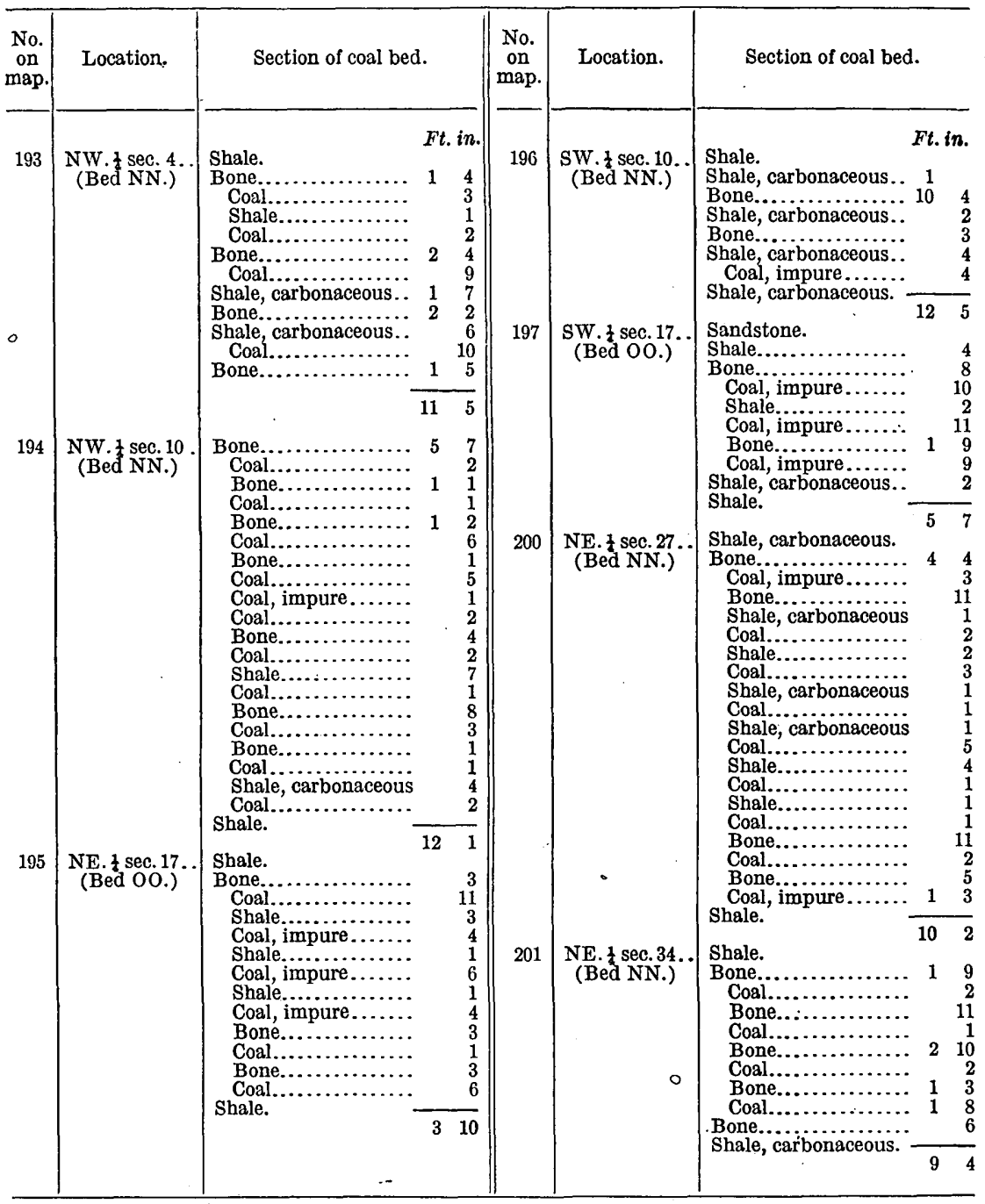

T. 10 N., R. 41 E.

The divide between Sunday Creek and the drainage system that lies to the west runs southeast through T. 10 N., R. $41 \mathrm{E}$. The stream valleys are generally fairly flat and the divide itself is not thoroughly dissected, but elsewhere the topography is of the badland type. The Lebo shale member underlies the northeast and southeast corners of the township. The rest of the township is underlain by either the Lebo member or the Lance formation, probably the former. (See p. 13.) No exact observations on the structure were made in this township, but the dip is probably about $1^{\circ} \mathrm{E}$. 
Coal bed NN, the approximate outcrop of which is indicated on the map, traverses the northeast corner of the township. In sec. 11 (location 204) it contains a total of 27 inches of coal, distributed through the bed in eight separate benches. At no other place in the township does it contain more than 11 inches altogether. $A$ bed which is probably bed $\mathrm{OO}$ was examined at location 203 in sec. 3, where it contains 20 inches of impure coal.

Sections of coal beds in T. 10 N., R. 41 E.

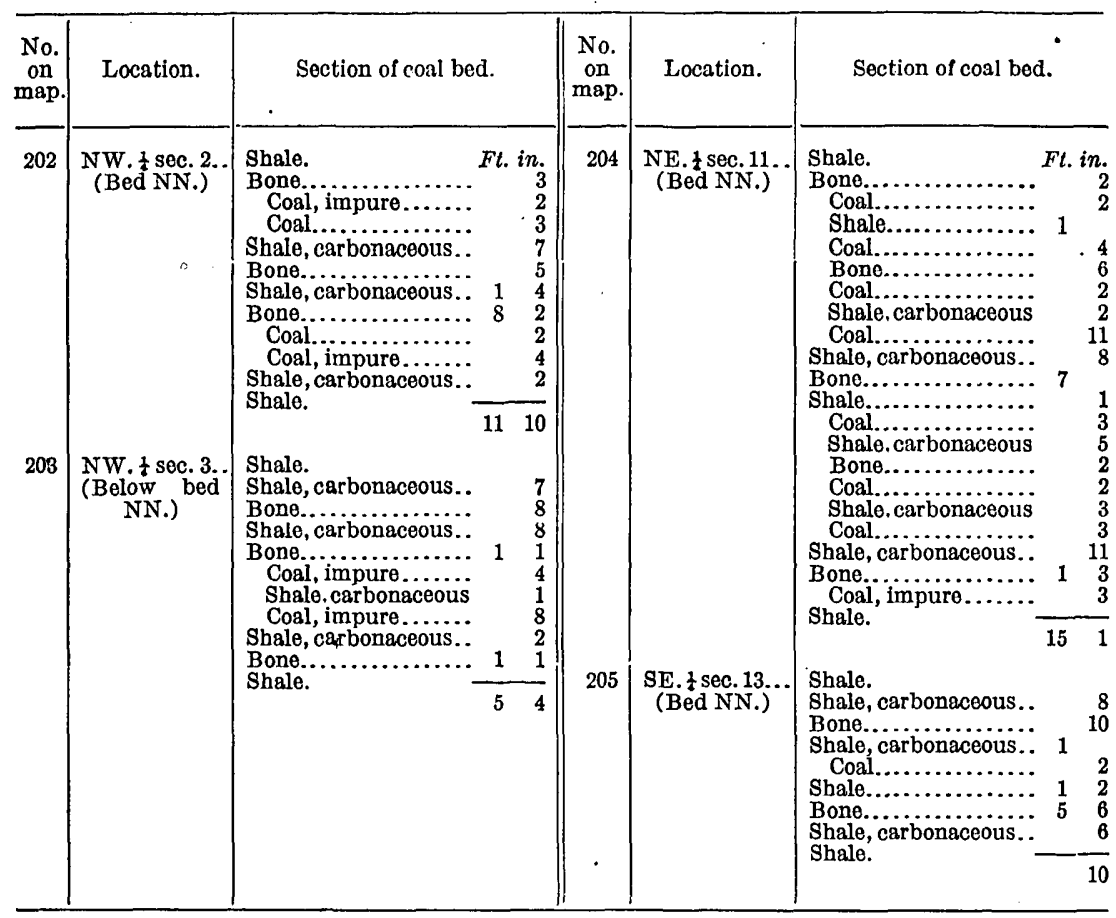

T. 9 N., R. 41 E.

Except a small strip in its eastern portion, drained by Horse Creek, T. 9 N., R. 41 E., is entirely within the Porcupine Creek drainage basin, which lies west of Sunday Creek. The topography is of the badland type, although most of the country is not excessively rough. The surface rock is either the Lebo shale member or the Lance formation, but probably the former. (See p.169.) No observations on the structure were made, but the dip is probably to the east.

No bed containing more than 14 inches of coal was exposed in this township. There are five carbonaceous zones, but they are made up of bone and shale with very little coal. The highest of these is probably bed NN, which crosses sec. 1 . 
T. 10 N., R. 42 E.

South Sunday Creek flows eastward across the northern part of T. 10 N., R. 42 E., and Louie and Scottie Creek traverses the southern part. The valleys of these creeks are fairly broad and flat and the intermediate divide is not thoroughly dissected, but the topography is of the badland type. The township is underlain by the Lebo shale member, but no observations on the structure were recorded.

Bed NN enters the westernmost tier of sections in the township for a short distance, but it probably contains less than 5 inches of coal. There are six other carbonaceous zones above this bed, but none of them contains more than 2 inches of coal.

T. 9 N., R. 42 E.

The area contained in T. 9 N., R. 42 E., is drained almost entirely from the south by Sand Creek. The topography is of the badland type and in many places the ground is badly broken. The northern part of the township is underlain by the Lebo shale member, and, though the surface rock in the southern part may be Lance formation, it is believed (see p. 169) that the Lebo is exposed throughout the whole area. No observations on the dip were recorded, but probably it is gentle and to the east.

Sections of coal beds in T. 9 N., R. 42 E.

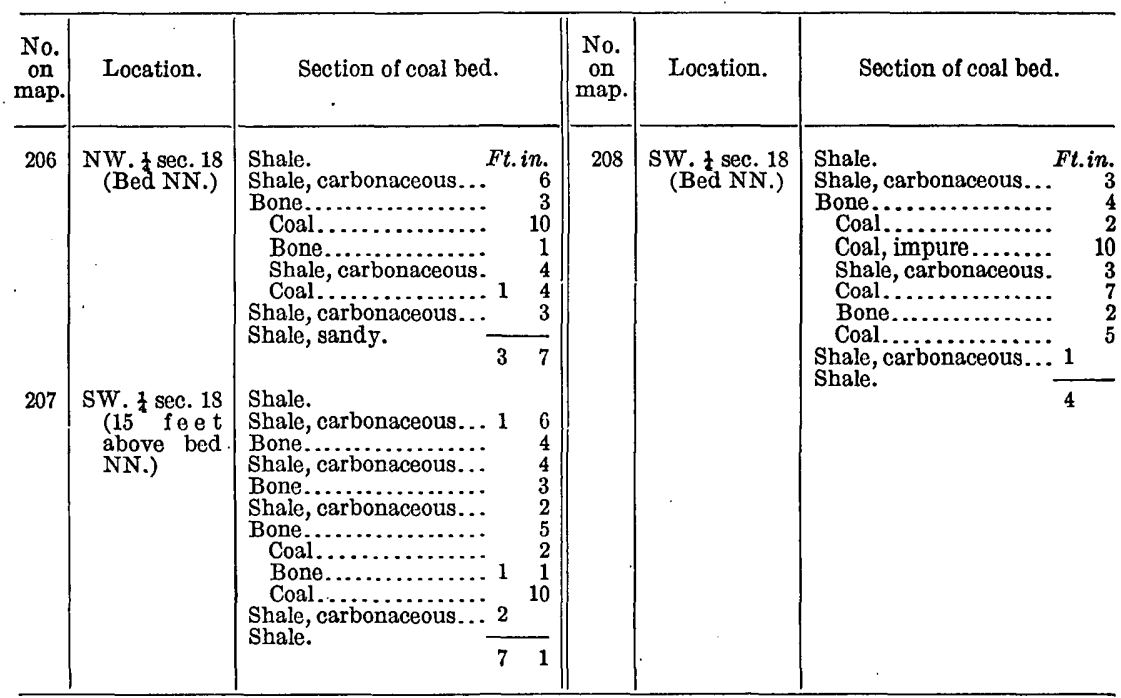

Bed NN crosses the township approximately as shown on the map (Pl. XIII). At location 206 in sec. 18 it contains 26 inches of coal in two benches separated by 5 inches of bone and shale, but a mile to the south it carries only 14 inches in three benches. (See 
sections 207 and 208, below.) Over the rest of the area it consists almost entirely of bone and shale. A bed 15 feet above $\mathrm{NN}$ in sec. 18 contains 12 inches of coal, but at no other place does it contain as much as this. There are five other carbonaceous zones in this township ranging in thickness from $3 \frac{1}{2}$ to 7 feet, but they consist almost entirely of bone and shale.

\section{T. 10 N., R. 43 E.}

Sunday Creek flows southeastward across T. 10 N., R. 43 E., and its valley, nearly 2 miles broad, is fairly flat. A zone of badlands borders the valley on either side, and most of the township outside of the valley is rather rough. The Lebo shale member constitutes the surface rock throughout this township except a small patch in sec. 1, which is underlain by the yellow beds of the Fort Union. No observations on the structures were recorded. There is but one carbonaceous zone in this township containing more than 6 inches of coal. This bed is exposed in the valley of Sunday. Creek and was examined at several places. At location 214 in sec. 34 it apparently reaches its maximum thickness, containing 17 inches of good coal:

Section of coal bed at location 214, in NE. $\frac{1}{4}$ sec. $94, T .10$ N., R. $43 \mathrm{E}$.

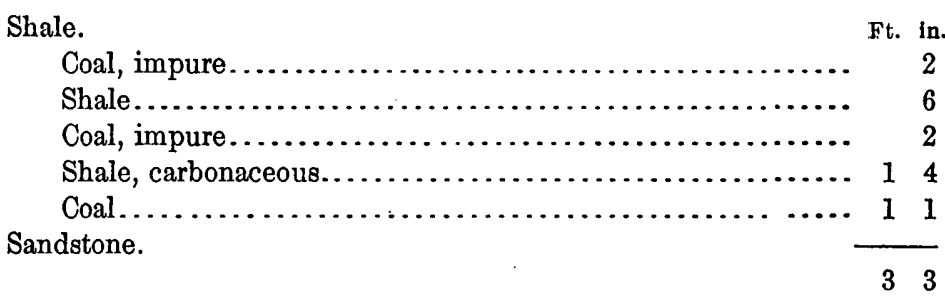

T. 9 N., R. 43 E.

The area contained in T. 9 N., R. 43 E., is drained by Louie and Scottie Creek, the divide on either side of this stream being roughly coincident with the north and south boundaries of the township. All the surface is broken by badlands except small grass-covered areas in the valleys of the creeks. The Lebo shale member is exposed throughout the township, but no exact observations on the structure were made.

Several carbonaceous zones outcrop in this township, but only one contains as much as 10 inches of coal. Sections 209 to 213 (see below) are probably all on this bed, although the bed on which section 209 was taken may be a few feet lower. The bed ranges in thickness from 5 to 13 feet, but nowhere contains more than 10 inches of coal. Two beds not shown on the map outcrop along the divide in the southernmost tier of sections. The total thickness of each is about 3 feet, but neither contains more than 3 inches of coal. 
Sections of coal beds in T. 9 N., R. 43 E.

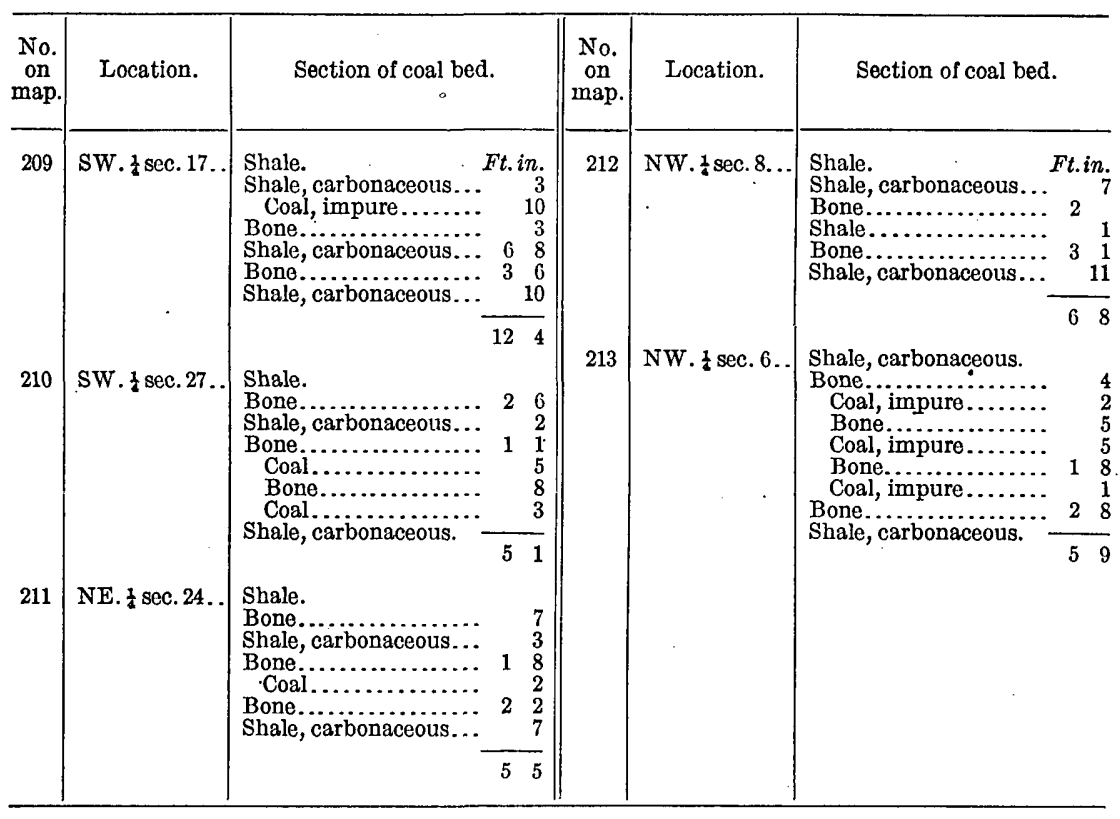

T. 10 N., R. 44 E.

The divide between Sunday and North Sunday creeks is included in T. 10 N., R. 44 E. A number of tributaries of both these streams have cut fairly deep valleys into this divide, which is an area of considerable relief. The yellow beds of the Fort Union formation, overlain in places by a thin layer of alluvium, cover the crest of the dissected divide, but the Lebo shale member is exposed upon its flanks. (See Pl. XIII.) The top of the divide in many places is smooth and rolling, but badlands characterize the country underlain by the Lebo shale member. No exact observations were made upon the structure in this township.

The yellow beds of the Fort Union, which immediately overlie the Lebo shale member, are barren of coal, but near the top of the Lebo two carbonaceous zones were found. The upper bed averages 4 feet in total thickness, but it does not contain as much as 24 inches of coal. The lower bed in few places is 2 feet in total thickness and does not contain more than 3 or 4 inches of coal.

Sections of coal beds in T. 10 N., R. $44 E$.

\begin{tabular}{|c|c|c|c|c|c|}
\hline $\begin{array}{c}\text { No. } \\
\text { on } \\
\text { map. }\end{array}$ & Location. & Section of coal bed. & $\begin{array}{c}\text { No. } \\
\text { on } \\
\text { map. }\end{array}$ & Location. & Section of coal bed. \\
\hline 215 & SE. $\frac{1}{2} \mathrm{sec} .30 .$. & 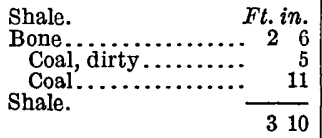 & 216 & NE. $\frac{1}{6} \mathrm{sec} .33$. & 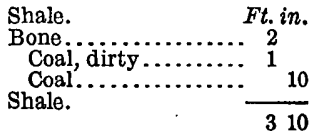 \\
\hline
\end{tabular}




\section{T. 9 N., R. 44 E.}

Sunday Creek flows southeast across T. 9 N., R. 44 E., in a valley over 2 miles broad, the remainder of the area being covered by badlands. The Lebo shale member constitutes the surface rock throughout the township, but no exact observations on its structure were recorded. Three carbonaceous zones are exposed in this area, but none of them contains more than 3 or 4 inches of coal. No other coal was found in this township.

\section{T. 10 N., R. 45 E.}

North Sunday Creek flows across the southwest corner of T. 10 N., R. $45 \mathrm{E}$., and two of its branches empty into it from the north in this area. There are two well-marked topographic provinces in this township. In the northern part of the township the yellow beds of the Fort Union formation, covered by a thin layer of alluvium, underlie a series of low, rolling hills. The ancient terrace, which the presence of this alluvium indicates, lies at an altitude of about 2,950 feet, and it was probably at one time continuous with the terrace whose remnant now exists in T. 13 N., R. 51 E. In the southern part of the township the Lebo shale member is exposed, and its outcrop is characterized by rough badlands. These beds, as elsewhere in the district, are nearly flat, but no exact measurements on the structure were made.

No coal is contained in the yellow beds of the Fort Union which outcrop in this township. "A bed about 60 feet below the top of the Lebo member was examined in several places (see sections 219, 220, and 221, below), but was found to be everywhere thinner than 24 inchès. In sec. 14 it contains 20 inches of impure coal, however, and a small amount has been mined for a near-by ranch.

Sections of coal beds in T. 10 N., R. $45 \mathrm{E}$.

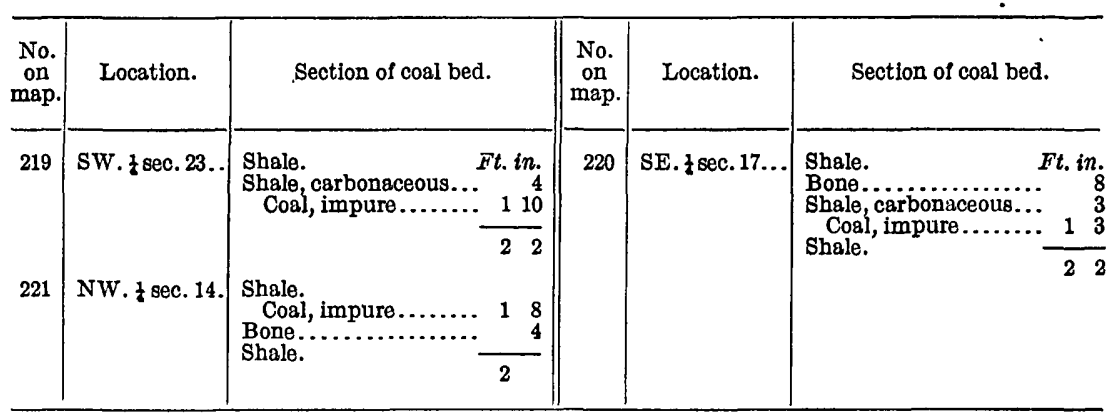

T. 9 N., R. 45 E.

North Sunday Creek flows across the northeast corner of T. 9 N., R. 45 E., and Sunday Creek across the southwest corner, so that the $60385^{\circ}-$ Bull. 531-13-14 
area includes the divide between these two streams. The valleys of both creeks are fairly" flat, but the country between is broken into very rough badlands. The Lebo shale member constitutes the surface rock throughout the township except for a small strip in the eastern part underlain by the Lance formation. No measurement of the very slight dip was made in this township.

Bed U outcrops along the eastern edge of this township in secs.13, 24, 25, and 36, as shown on Plate XIII. In sec. 25 it contains 16 inches of coal. (See section 227, below.) A bed considerably higher than this one outcrops in the valley of North Sunday Creek, but, although 4 feet or more in total thickness, it contains less than 1 foot of coal. (See section 217.) There is also a 3-foot bed, about 60 feet higher than the bed last mentioned, but this bed at no place contains more than 6 inches of coal.

Sections of coal beds in T. 9 N., R. $45 E$.

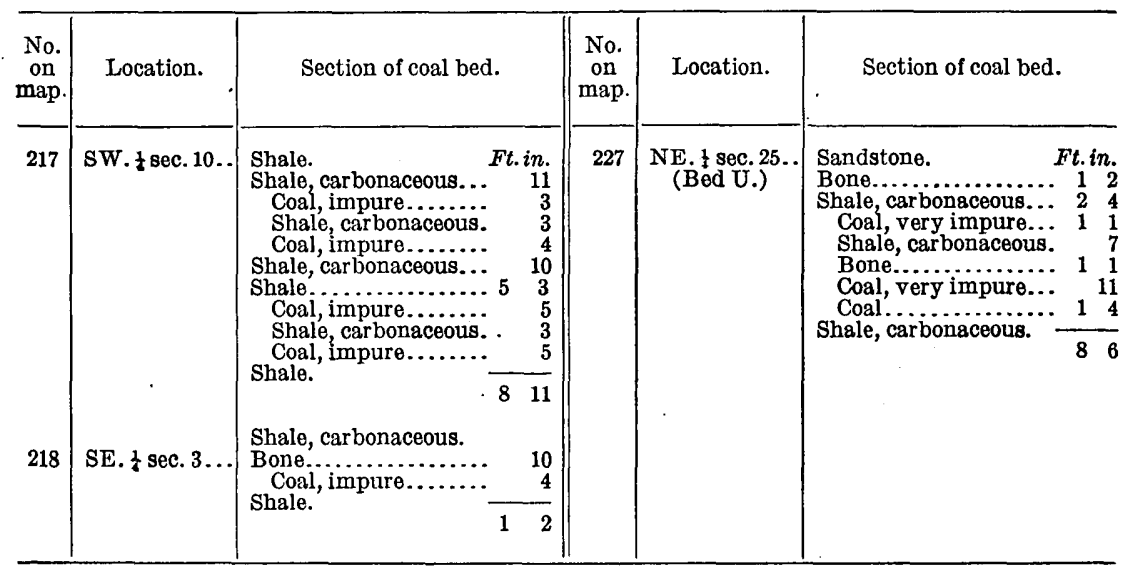

T. 10 N., R. 46 E.

The northeast corner of T. 10 N., R. 46 E., is drained by Sand Creek and the remainder of the area by branches of North Sunday Creek. The contact between the yellow beds of the Fort Union formation and the Lebo shale member runs through the area and separates the township into two distinct topographic districts. The nortbwestern part, which is underlain by the yellow beds, is a gently rolling prairie, whereas the eastern and southern parts of the area are broken into nearly impassable badlands.

The yellow beds exposed in this township are the lower part of the yellow strata and here as elsewhere are non coal bearing. Two carbonaceous beds, 60 and 100 feet, respectively, below the top of the Lebo member, outcrop in the valley of Sand Creek. Each is about 2 feet thick, but both beds are made up entirely of bone at all places examined. 
T. 8 N., R. 46 E.

North Sunday Creek flows across the southwest corner of T. 9 N., R. $46 \mathrm{E}$., in a fairly flat valley over a mile wide. Coal U, which marks the base of the Lebo shale member, crosses the area in a general east-west direction, and the land to the north, underlain by this formation, is very rough badland country. In the southern part of the township the Lance formation is exposed and the ground is somewhat less minutely dissected than to the north. No exact observation on the structure. was made.

Sections of coal beds in T. 9 N., R. $46 E$.

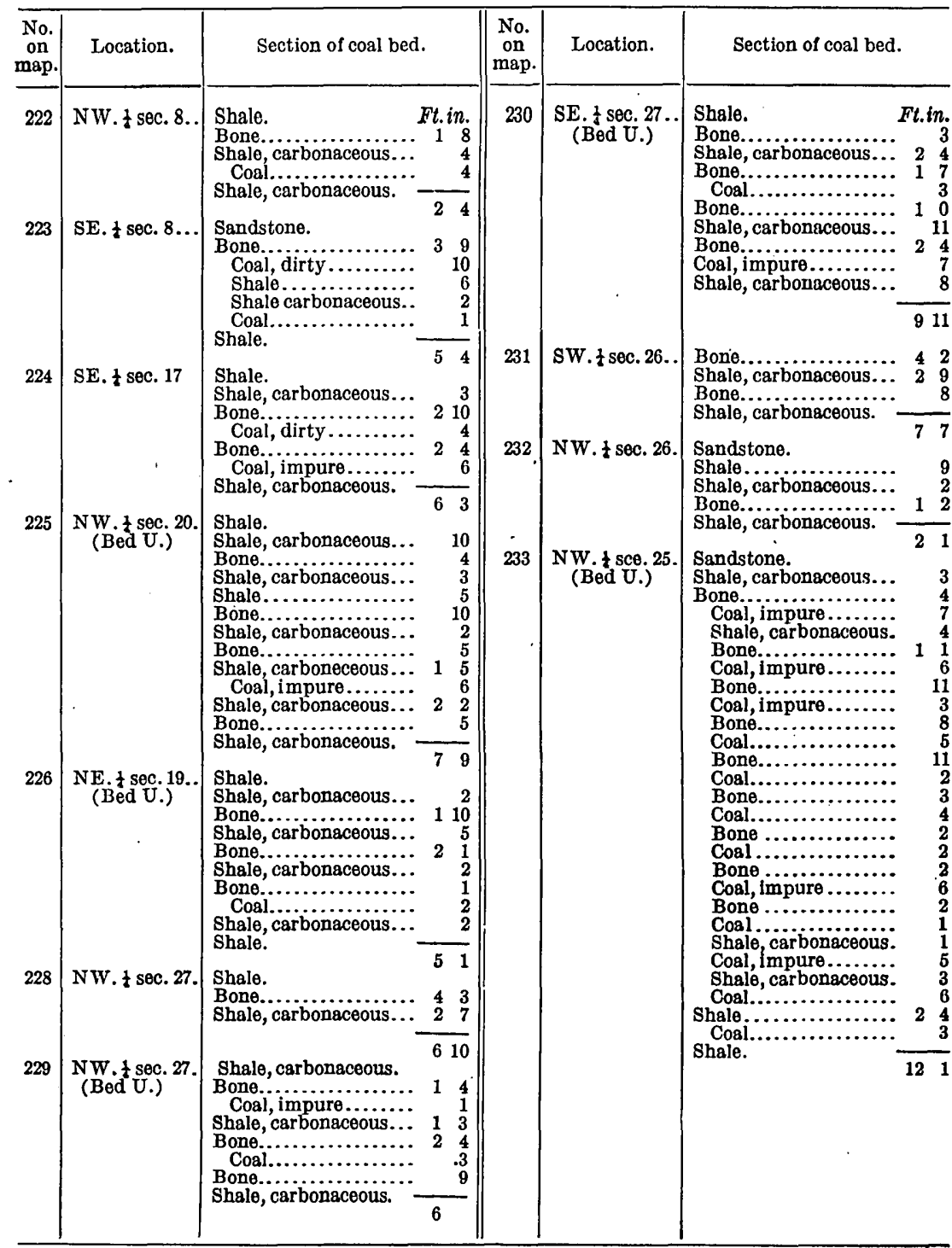


Four carbonaceous zones outcrop in this township. The highest is the bed which has been noted before as being fairly persistent about 70 feet below the top of the Lebo; it is of no value in this township. (See section 222, p. 55.) The second bed is composed chiefly of carbonaceous shale and bone with less than 12 inches of coal. (See sections 223 and 232.) The third bed (see sections 224, 228 , and 231) averages over 5 feet in total thickness, but contains less than 12 inches of coal. Bed $U$ is very lenticular in character, but at no place is it commercially valuable. At location 227, in sec. 25 of the township to the west, it carries 16 inches of coal; thence east to sec. 25 of this township it contains a total of less than 1 foot of coal. At location 233 it carries about $2 \frac{1}{2}$ feet of coal, separated into seven distinct benches by partings of bone and shale ranging in thickness from 2 inches to 2 feet. (See sections 225, 226, 229,230 , and 233 , p. 55.)

T. 8 N., R. 47 E.

The stream formed by the confluence of Sunday and North Sunday creeks enters T. 9 N., R. 47 E., in sec. 33, flows northeast for about 2 miles, and then turns at right angles and empties into Yellowstone River. In sec. 33 and the area to the southwest, where the stream flows parallel to the river, the divide is a 300 -foot ridge covered with alluvium, which represents the lowest of the three terraces described above (p. 161). The outcrop of bed U, which marks the base of the Lebo shale member, enters this township in sec. 30 and trends nearly north, so that in the greater part of the area the Lance formation is the surface rock. The topography is rough, but it is not in general of the badland type Accurate measurements of the dip were not recorded.

The two upper beds $U$ and $V$, exposed in this township, were measured repeatedly (see below) and are so irregular in character and so split by partings as to be of little or no commercial value. Bed U ranges in total thickness from 3 to 19 feet and contains from 3 inches to 5 feet of more or less impure coal. It does not carry so much as 24 inches of coal in one unbroken bench. Bed V is in general slightly thinner than $U$ and does not contain a total of more than 24 inches of coal. The distance between the two beds ranges from 51 to 75 feet.

In the valley of Sunday Creek a bed outcrops that is thought to correspond to the Kircher coal in the Miles City field, ${ }^{1}$ which is contiguous to this area on the south. The Kircher coal is described as being "exceedingly variable and workable only in small areas" in the Miles City field. Sections 236 to 238, given below, show that the bed in this district commonly contains about 3 feet of coal but not as much as

\footnotetext{
1 Collier, A. J., and Smith, C. D., The Mules City coal field, Montana; Bull. U. S. Geol. Survey No. 341,1907, p. 36.
} 
24 inches in one unbroken streak. Its outcrop therefore was not mapped. Some distance above this coal bed two bands of bone and carbonaceous shale occur, which may correspond to the Laney coal of the Miles City field. Neither band, however, reaches a thickness greater than 18 inches.

Sections of coal beds in T. 9 N., R. $47 E$.

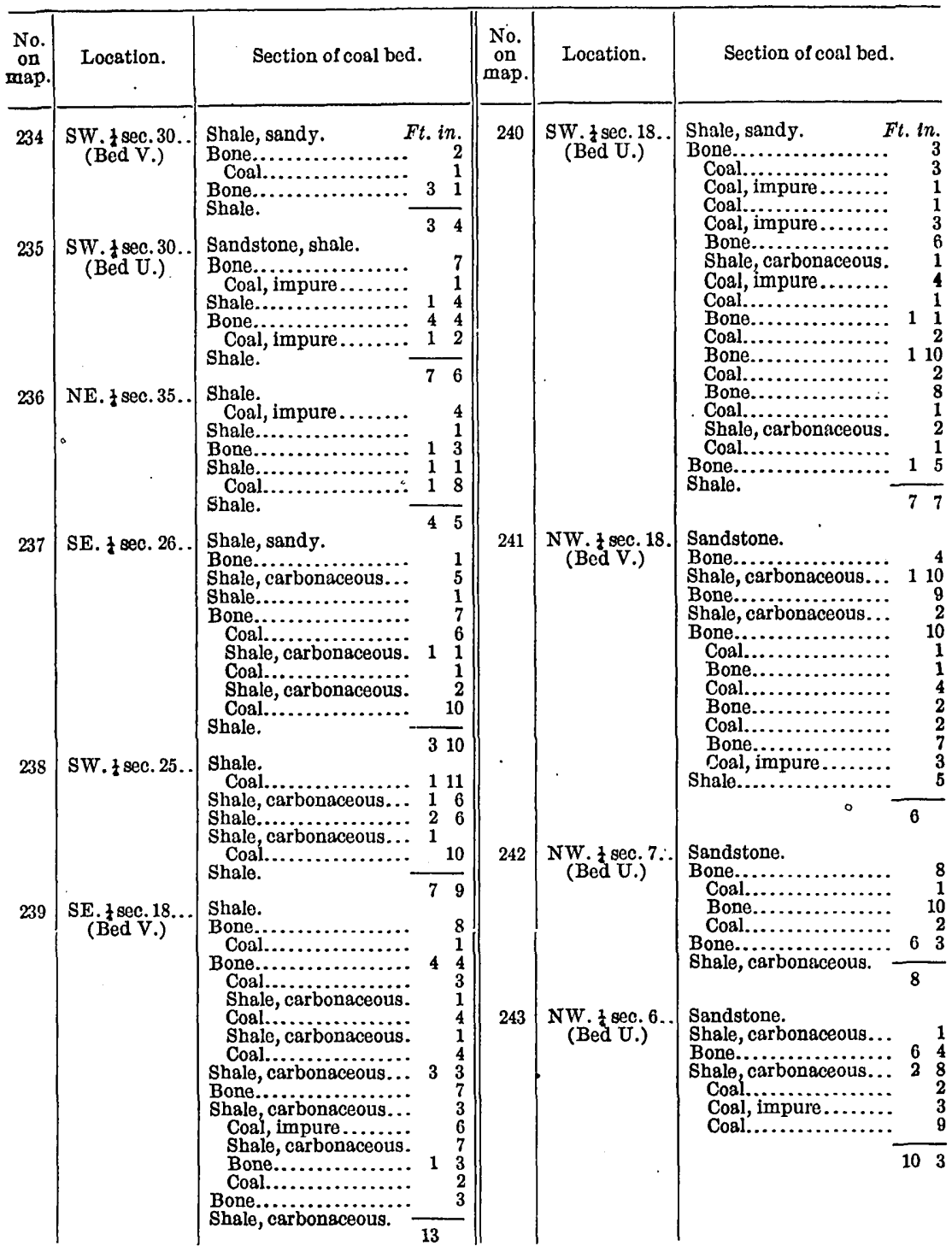


Sections of coal beds in T. 9 N., R. 47 E.-Continued.

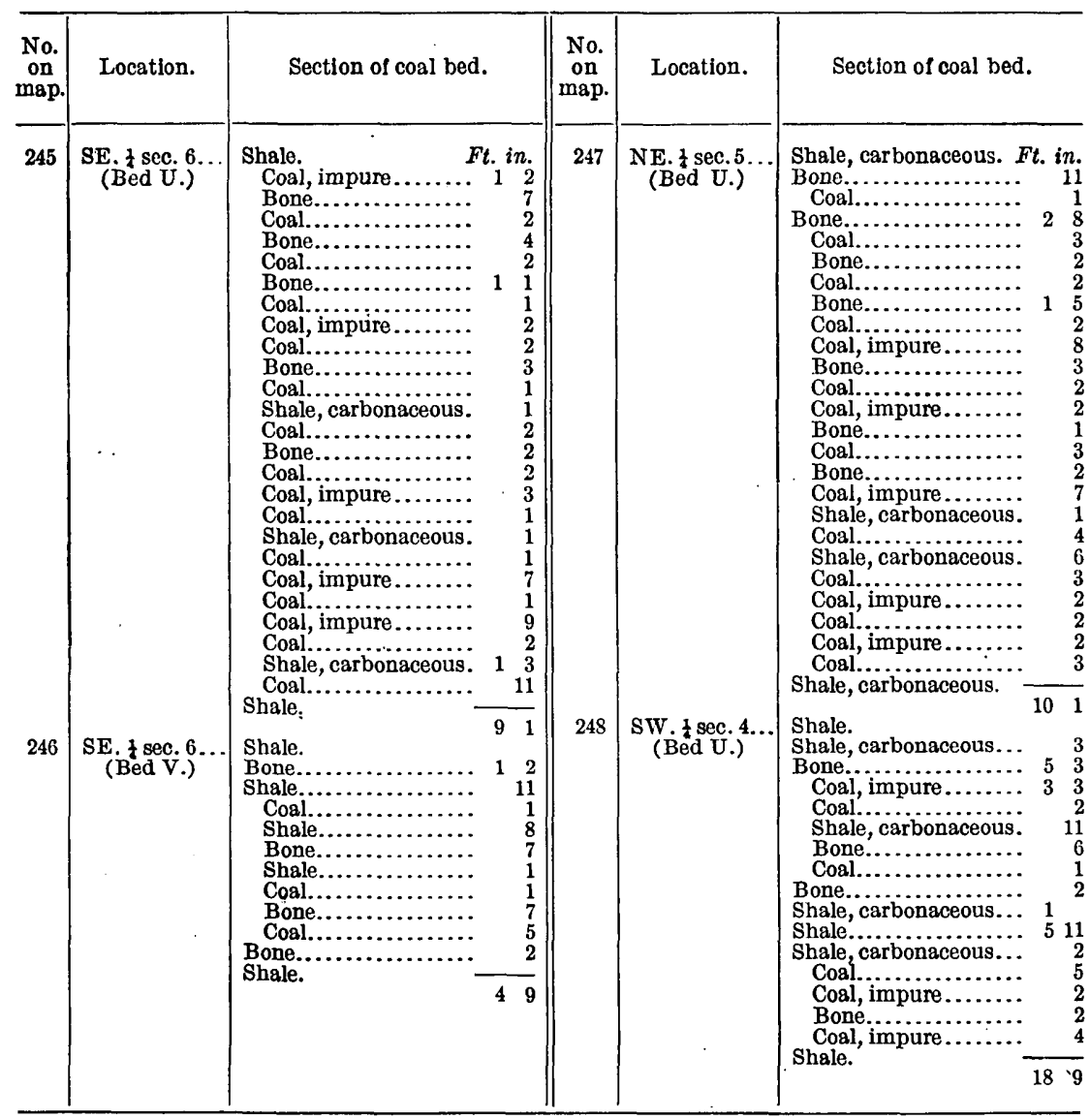

T. 10 N., R. 47 E.

Sand and Muster creeks flow southeastward across T. 10 N., R. 47 E., separated by a fairly high divide, the crest of which is capped by a tongue of the yellow beds of the Fort Union formation projecting down from the north. In secs. 1 and 2 on the divide north of Muster Creek there is a similar area. (See map, Pl. XIII.) Bed U, which marks the base of the Lebo shale member, crosses the township diagonally, and below this bed the Lance formation is exposed. The area underlain by Lebo is characterized in general by rough badlands which are in places almost impassable. The southeast part of the township, in which the Lance outcrops, is fairly flat, however, and forms a striking contrast to the badlands. The rocks dip to the east from 4 to 6 feet in 1,000 . 
Sections of coal beds in T. 10 N., R, $47 \mathrm{E}$.

[In addition to sections shown on Pl. XII.]

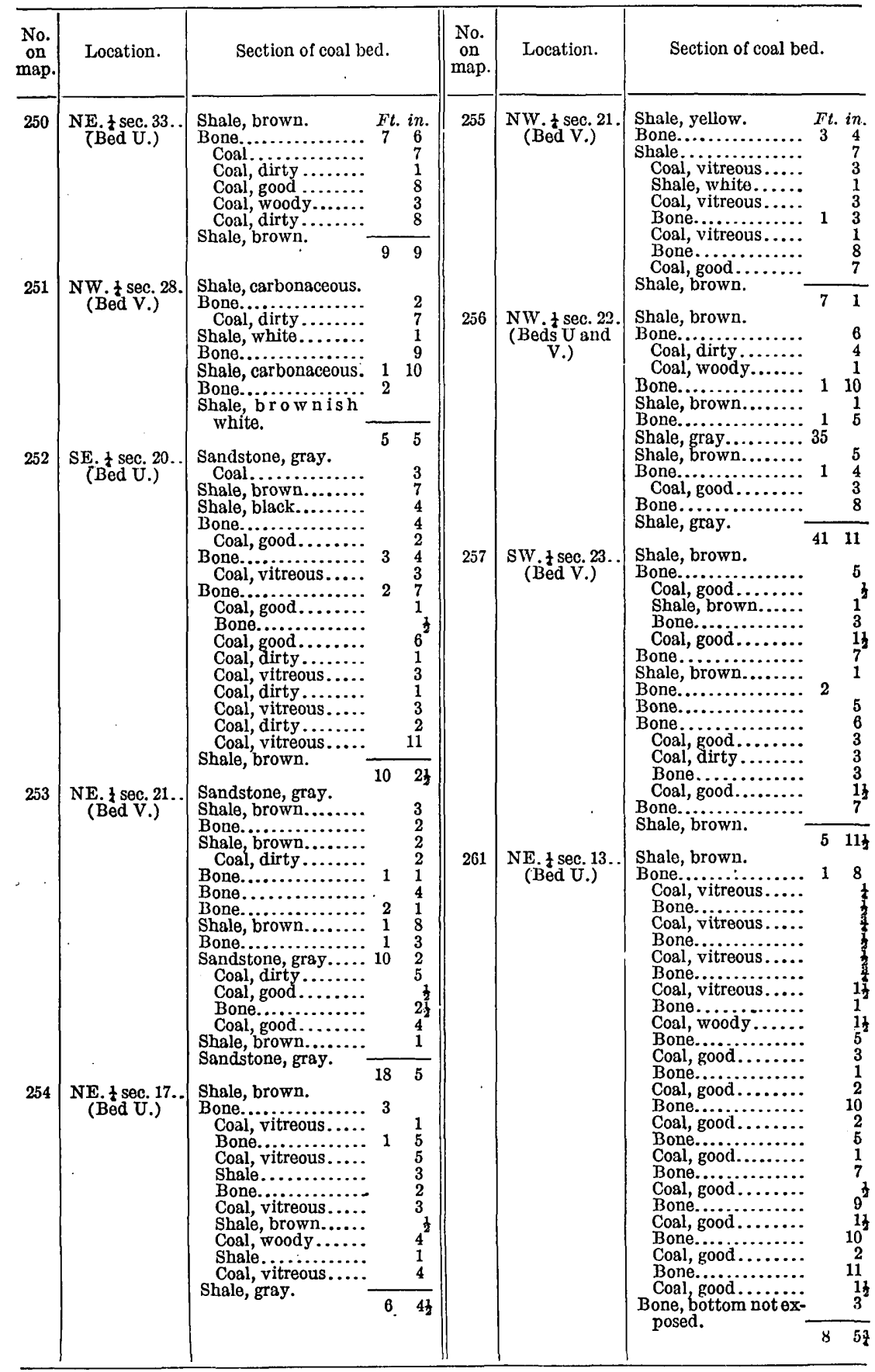


The outcrop of beds $U$ and $V$, as shown on the map, follows up the valleys and around the divides of the two creeks traversing the township. Bed U ranges in total thickness from 5 to 13 feet, whereas bed $\mathrm{V}$ maintains a fairly constant total thickness of 7 feet. In the western half of the township, however, bed U contains only impure coal; in the eastern half, particularly at location 259, it is better. (See sections 244,249, 258, 259, and 260, Pl. XII.) The thickness of the bed, however, is such as to attract attention, so that strip pits have been opened at several places and small amounts of impure coal have been removed. The bed is lenticular, and possibly at some concealed places between the points at which examinations were made it may contain 4 or 5 feet of good coal; but it is believed that the sections given are fairly representative. Bed $\mathrm{V}$ is of even less importance than bed U; at no point examined does it show a total of more than 20 inches of coal.

\section{T. 9 N., R. 48 E. (FRACTIONAI).}

Yellowstone River traverses T. 9 N., R. 48 E., in a northeasterly direction, so that only the northwest portion is included in the area discussed in this paper. The ground is nearly flat and there are practically no rock exposures. The Lance formation underlies the township, but its exact structure was not investigated. No coal is exposed and well records prove that no bed underlies the township at a depth less than 40 feet.

\section{T. 10 N., R. 48 E.}

Harris Creek traverses the northeast corner of T. 10 N., R. 48 E., and the divide between this stream and Muster Creek runs diagonally across the center of the area. The crest of this divide is capped by $a$ tongue of the yellow beds of the Fort Union formation and small outlying areas crown many of the highest buttes. Bed U, which marks the base of the Lebo shale member, follows around the edge of this divide and up the valley of Harris Creek. (See Pl. XIII.) The territory underlain by the Lebo shale member is broken into nearly impassable badlands, but below coal bed $U$ the Lance formation is exposed and produces a nearly flat country in the southern part of the township. The strata in sec. 20 dip 2 feet in 1,000 to the west and in sec. 15 they dip 3 feet in 1,000 to the north. These dips probably indicate the presence of a very gentle dome in the southern part of the area.

Beds $U$ and $V$ are exposed near together and therefore their outcrops were traversed and mapped as one line. Bed U ranges in total thickness from 6 to 25 feet (see sections 262, 263, 269, and 271, Pl. XII), but the bed only locally contains more than a solid 2-foot bench of good coal. In sec. 10, however, it carries nearly 4 feet of good coal 
in one bench, and in small areas the bed may thus be of value. From a strip pit in sec. 11 about 30 tons of coal have been removed, but the bed is badly broken at this place by bone and shale partings (location 271). Bed V is similarly lenticular in character and is generally thinner, but in sec. 10 it carries $2 \frac{1}{2}$ feet of impure coal. The stratigraphic distance between beds $U$ and $V$ ranges from 11 to 28 feet. As these beds lie at the base of the Lebo they outcrop at the foot of the badlands and the cover is generally thick. The beds are burned in many places and a fairly heavy clinker is produced.

Sections of coal beds in T. 10 N., R. $48 \mathrm{E}$.

[In addition to sections shown on PI. XII.]

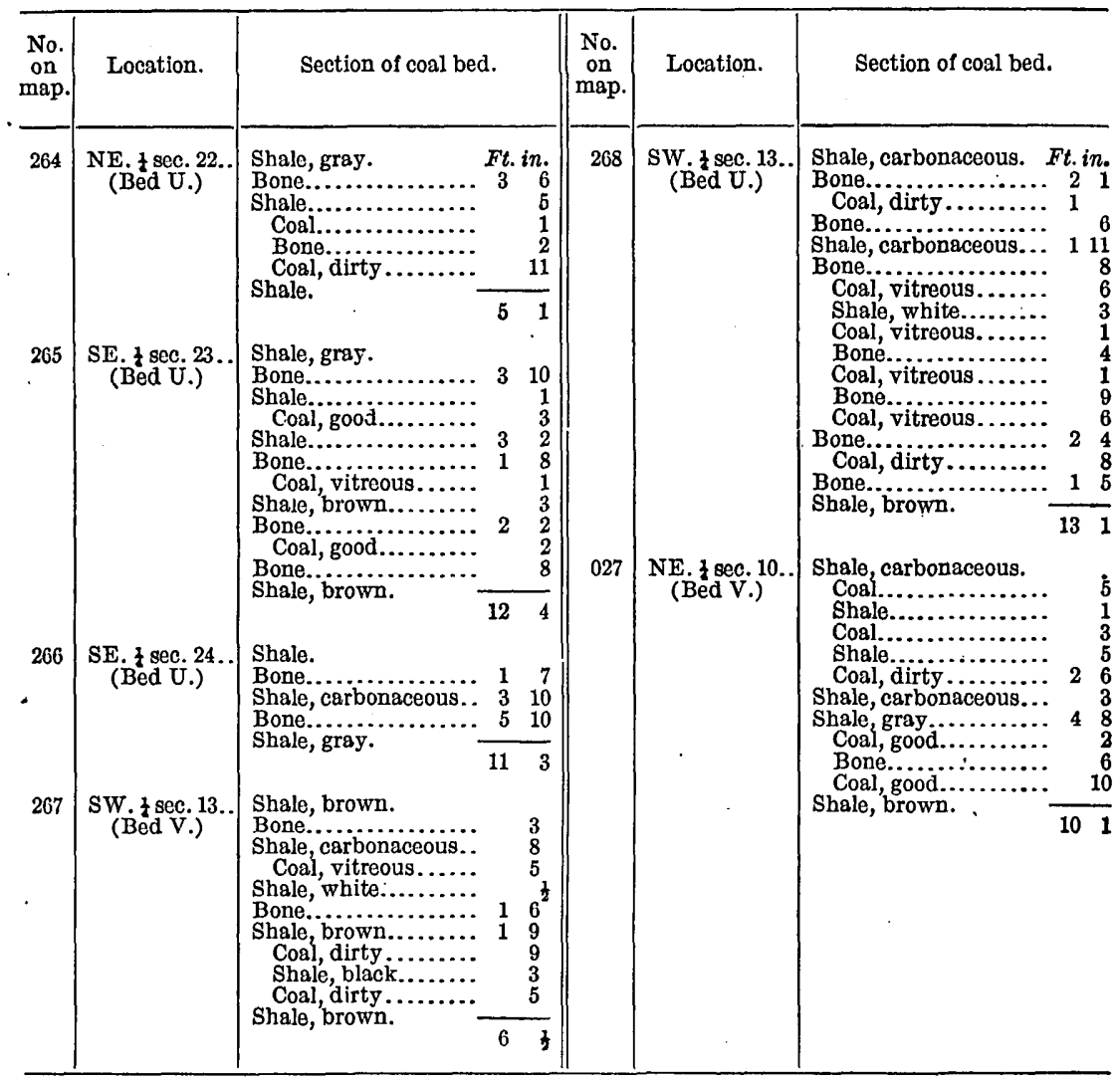

T. 11 N., R. 48 E.

Custer Creek flows across the northeast corner of T. 11 N., R. 48 E. and Harris Creek across the southwest corner. The broad high divide between these streams occupies most of the area. The yellow beds of the Fort Union formation are exposed on the crest of this divide and the Lebo shale member on its lower slopes. The topography of 
the whole township is very rough. The yellow beds of the Fort Union are broken by many small spurs and buttes and dissected by deep coulees, whereas the Lebo shale is characterized by typical badlands. No exact determination of the structure wais made in this township.

The yellow beds of the Fort Union contain no coal of importance. There is only one bed, and it carries but 6 inches of coal. (See section 279, below.) Near the top of the Lebo member a small bed was examined in several places (see section 280 , below), but it contains only 11 inches of coal at location 280. A lower bed that outcrops in the valley of Custer Creek has a total thickness of 6 feet but contains only 7 inches of coal (section 282).

Sections of coal beds in T. 11 N., R. 48 E.

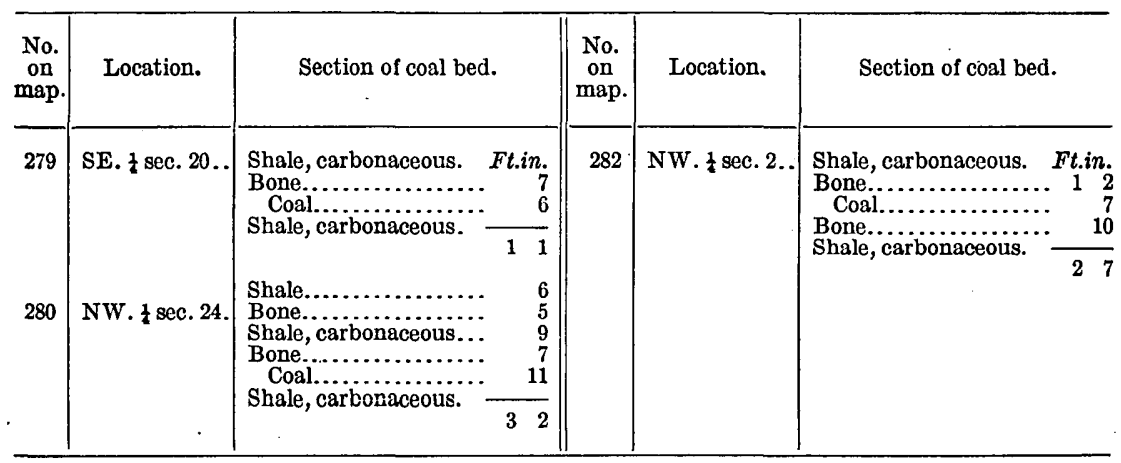

T. 9 N., R. 49 E. (FRACTIONAL).

Yellowstone River crosses the northwest corner of T. 9 N., R. 49 E., and only a portion of sec. 6 is included in the district here discussed. The ground is almost flat and is underlain by the Lance formation. No coal is exposed in this area.

\section{T. 10 N., R. 49 E. (FRACTIONAL).}

Yellowstone River traverses T. 10 N., R. 49 E., and only the western portion of the township is included in the district described in this report. The northwest corner of the township contains rough badlands, but between the river and the outcrop of coal $U$, which marks the base of the Lebo shale member, the ground is fairly level. This area is underlain by the Lance formation, but two hills capped by Lebo shale rise abruptly within it. The larger of these hills, which represents the extremity of the north divide of Harris Creek, is partly covered by alluvium. This ancient terrace, the lowest of those mentioned on page 161, lies at an altitude of 2,550 feet or nearly 300 feet above the river. The strata in this township dip 4 feet in 1,000 to the northeast. 
Beds $U$ and $V$ are exposed close together in this township, and therefore their outcrops are mapped as one line. In sec. 5 bed $\mathrm{V}$ is 10 feet below bed $U$, but the distance between the beds in sec. 19 is 39 feet. At location 272, in the NW. $\frac{1}{4}$ sec. 19 , bed V is 7 feet thick, but consists entirely of shale and bone. At no point in this township does bed V contain as much as 1 foot of coal. (See sections 272 and 274, below.) Bed U (see sections 276, 277, and 278, Pl. XII) in secs. 5 and 6 is about 20 feet in total thickness and carries at one place a total of $6 \frac{1}{2}$ feet of coal, badly split up, however, by bone and shale partings and containing but one bench of coal 24 inches thick. The total thickness of the bed and the amount of its coal decreases to the south; in sec. 19 it is 14 feet thick and carries only 13 inches of impure coal.

The cover of bed $U$ in sec. 5 is commonly less than 20 feet for a quarter of a mile back from the outcrop, but at about this distance it increases to 60 feet or more. The bed is only locally burned in this township.

Sections of coal beds in T. 10 N., R. 49 E.

[In addition to sections shown on Pl. XII.]

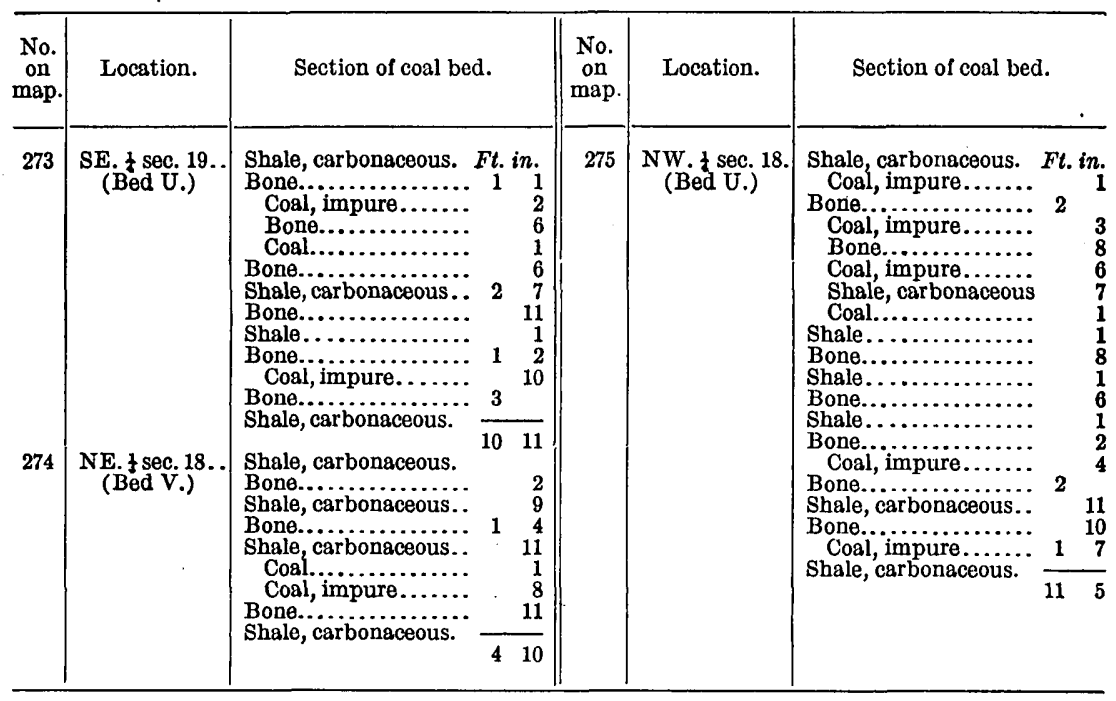

T. 11 N., R. 49 E.

Custer Creek flows southeast in a broad and fairly flat valley across T. 11 N., R. 49 E. Bed U, which marks the base of the Lebo shale member, follows around the divides and up the valley of this stream. The country underlain by the Lebo, which includes about twothirds of the township, is broken into very rough and in many places nearly impassable badlands, but that in which the Lance formation 
is exposed is relatively flat. The stratigraphic sections given above (see pp. 166-173) were measured in this area. Altitudes determined on the coal indicate that the creek in this township occupies a gentle syncline, the eastern limb of which dips more steeply than the western. In the northeast corner of the area the strata dip over $1^{\circ} \mathrm{NW}$.

Three beds are exposed in this township-R, U, and W. Bed $R$ in sec. 11 (location 295) carries more than 2 feet of coal, but it is split into benches 12 inches or less in thickness. The bed becomes thinner and disappears in a short distance. Bed U, which is stratigraphically 65 feet below bed $R$, reaches its maximum known thickness in this township. (See sections 283, 284, 285, 286, 287, 288, 289, 291, 292, 293, 294, 296, and 297, Pl. XII). The bed in sec. 32 (location 283 ) is 33 feet in total thickness, and of this $10 \frac{1}{2}$ feet is coal, which occurs in benches less than $2 \frac{1}{2}$ feet thick, separated by bone and shale partings. In sec. 22 (location 286), however, the bed carries about 3 feet of coal in one bench and in sec. 15 (location 289) almost 10 feet in one bench. In sec. 1 (location 297) it carries less than 2 feet in one unbroken bed. Bed W, which is stratigraphically about 22 feet below bed $U$, contains practically no coal in this township, and therefore its outcrop was mapped for only a short distance.

Bed $U$ is burned and heavily clinkered on the north side of the creek. Its cover is commonly less than 50 feet for a quarter of a mile back from the outcrop but at about this distance it generally increases to 80 or 100 feet.

Sections of coal beds in T. 11 N., R. 49 E.

[In addition to sections shown on Pl. XII.]

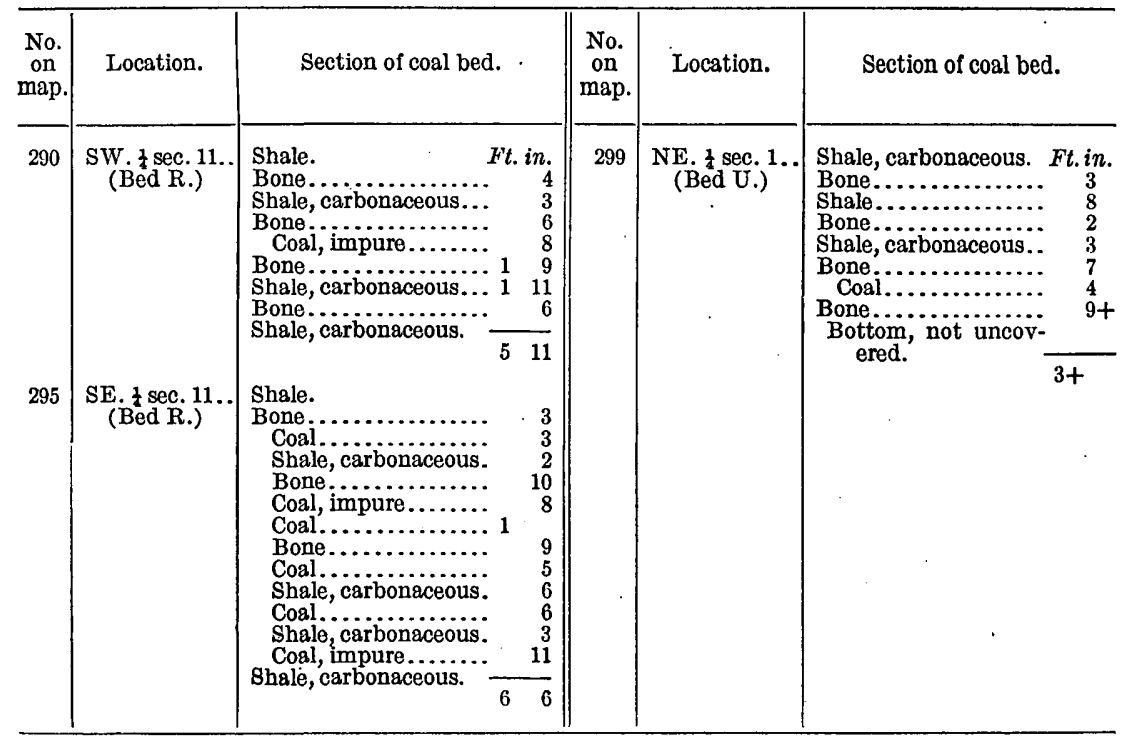




\section{T. 12 Nै., R. 49 E.}

The contact between the Lebo shale member and the yellow beds of the Fort Union formation crosses T. 12 N., R. 49 E., from sec. 1 to sec. 19. The northwest portion of the area, underlain by the yellow beds, is a plateau dissected by deep coulees and broken by many small spurs or buttes. The country in which the Lebo member outcrops is marked by badlands of the roughest sort, except for the fairly flat valley of Crooked Creek; many of the buttes are high enough to retain caps of the yellow beds of the Fort Union. Coal U, which marks the base of the Lebo, crosses the southeast corner of the township. The structure of the beds was not determined in this township.

Coal beds $H$ and $J$ are exposed for a short distance in sec. 6, but the outcrop is burned and the beds are so concealed that no examination could be made. The approximate location of the outcrop of bed QQ is shown on the map, but the bed was not traversed. It contains 26 inches of coal (location 303) in sec. 22 but becomes thinner both northwest and southeast and disappears in a short distance southeast. (See sections 301 and 304, below.) It was not traced into T. 12 N., R. 50 E., but it lies at about the same horizon as bed $Q$. Bed $U$ in this township contains practically no coal. Bed W is exposed in the valley of Crooked Creek for a short distance in sec. 36 (location 300), but although 14 feet in total thickness it carries only slightly more than 2 feet of coal.

Sections of coal beds in T. 12 N., R. $49 E$.

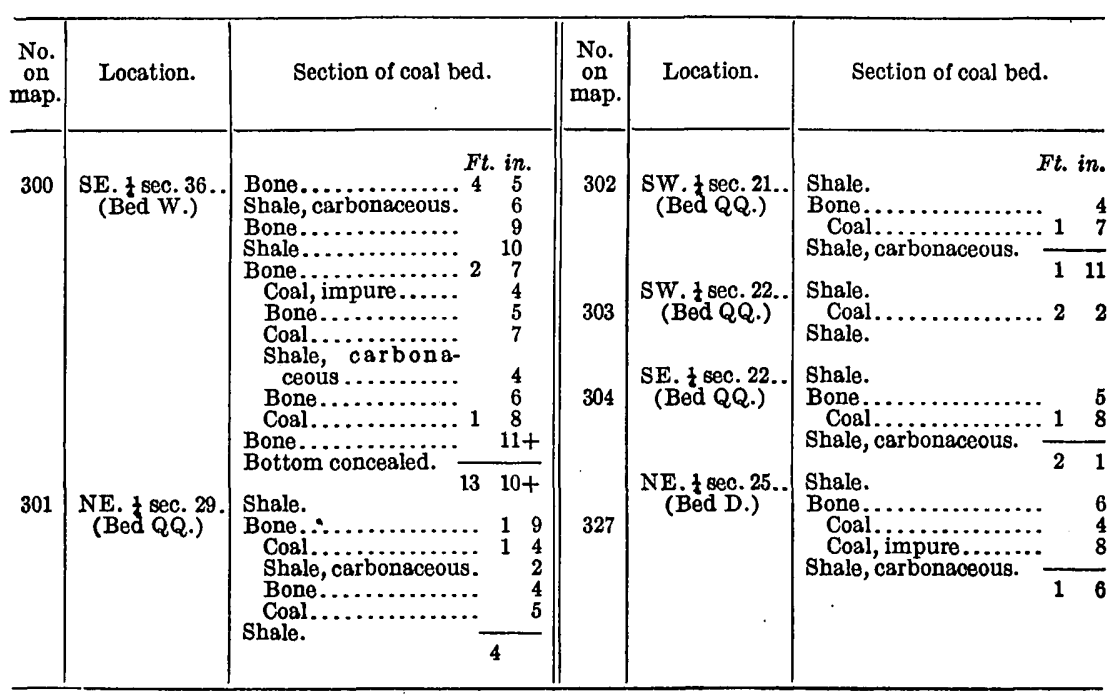




\section{T. 11 N., R. 50 E. (FRACTIONAL).}

Yellowstone River traverses T. 11 N., R. 50 E., and only the northwest corner is included in the district described in this paper. The surface is practically flat and is underlain by the Lance formation. Coal bed W is exposed in the extreme western portion of the township, but it is of no value, as shown by the following section:

Section of bed $W$ at location $298, S W . \frac{1}{4} \sec .6, T .11$ N., R. 50 E.

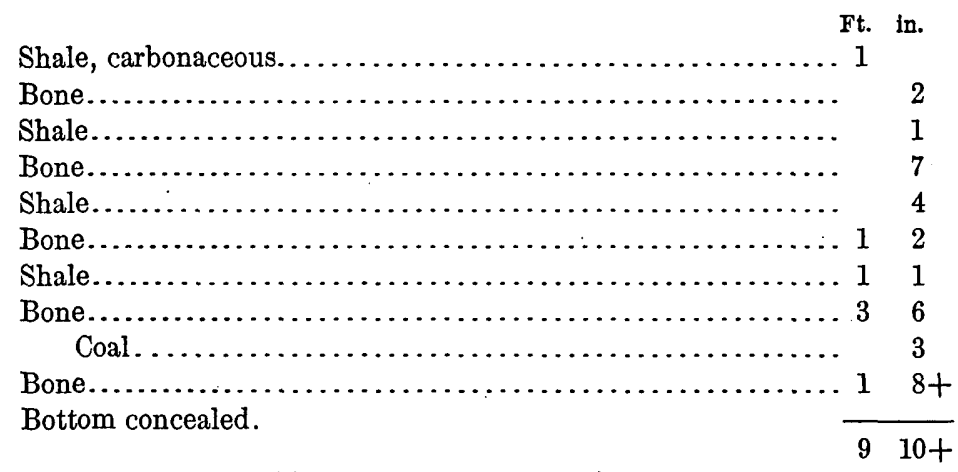

T. 12 N., R. 50 E. (FRACTIONAL).

Practically the whole of that portion of T. 12 N., R. 50 E., which is included in the area described in this report, is broken into nearly impassable badlands. The Lebo shale member is exposed in most of the area, but the yellow beds of the Fort Union outcrop along the northern border and isolated areas of these beds cap many of the highest buttes. Bed U, which marks the base of the Lebo, outcrops along the foot of the badlands, generally leaving between its outcrop and the river a narrow strip of flat country underlain by the Lance formation.

Stratigraphic section measured west from Calypso in sec. 27.

Sandstone, yellow, arkosic........................ 25

Conglomerate, composed of dark-yellow sandstone pebbles....... 10

Shale, yellow, sandy ............................... $\quad 30$

Shale, dark gray (marking top of Lebo) $\ldots \ldots \ldots \ldots \ldots \ldots \ldots \ldots \ldots . .68$

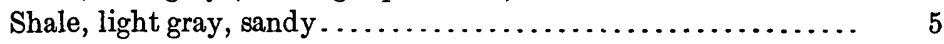

Coal P (see Pl. XII, sections $311,313,316,319,324,325$ )... 5

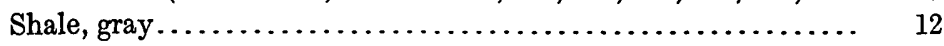

Sandstone, yellowish gray, compact..................... 5

Shale, carbonaceous................................ 2

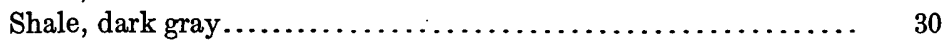

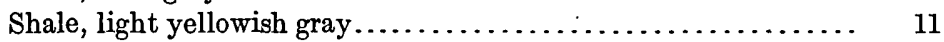

Shale, bright yellow, compact....................... $\quad 2$

Shale, yellowish gray, sandy........................ 18

Coal Q (see Pl. XII, sections $315,323,330) \ldots \ldots \ldots \ldots \ldots . \quad 5$

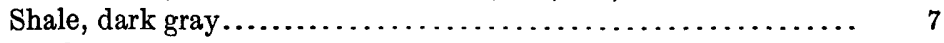

Sandstone, yellow, compact....................... 2 
Feet.

Shale, dark gray.................................. 52

Coal $U$ (marking the base of Lebo member) (see Pl. XII,

sections $314,318,320,337,338,340,347,348) \ldots \ldots \ldots \ldots . \ldots 11$

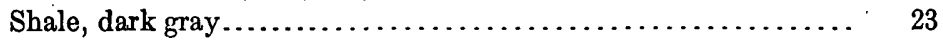

Coal W (see Pl. XII, section 317 )................. 4

Shales and sandstones to river. . . . . . . . . . . . . . . $100 \pm$

$447 \pm$

Altitudes obtained on the coal beds in this township indicate that Sheridan Butte in sec. 29 is about at the top of a gentle dome. In sec. 11 the dip is 7 feet in 1,000 southwest. In the northern part of this township and in the southern part of T. 13 N., R. 50 E., altitudes were determined at three points about 4 miles apart on the base of a heavy clinker which is visible as a cap rock for a long distance. These altitudes indicate a dip N. $47^{\circ} 37^{\prime}$ E. of 7 feet in 1,000 , but this dip may be complicated by minor rolls.

As indicated on the map, the two upper beds in this township are of importance in only a small area. Bed $\mathrm{P}$ generally consists of two benches separated by 1 to 4 feet of shale, the upper bench carrying about $1 \frac{1}{2}$ feet of coal and the lower 2 or 3 feet. Bed Q, throughout much of the distance mapped, is 6 or 8 feet in total thickness but only locally carries as mucb as 3 feet of coal. Bed U carries barely 2 feet of coal in the western part of the township, but in the central eastern part it is thicker and contains as much as a total thickness of $5 \frac{1}{2}$ feet of coal. It is, however, very lenticular and is generally split up by bone and shale partings into benches 24 inches or less in thickness. In sec. 21 bed $U$ divides and the lower member is called bed $W$. (See fig. 4, p. 170.) This bed is generally about 8 feet in total thickness, but it commonly contains less than 24 inches of coal, and at location 307 is composed entirely of bone and shale. Beds $\mathrm{S}$ and $\mathrm{T}$ are also exposed in this township, but neither contains a total of 24 inches of coal.

The coal beds are only locally burned. The cover is in general thick, being usually more than 50 feet on the highest coal.

Sections of coal beds in T. 12 N., R. $50 \mathrm{E}$.

[In addition to sections shown on Pl. XII.]

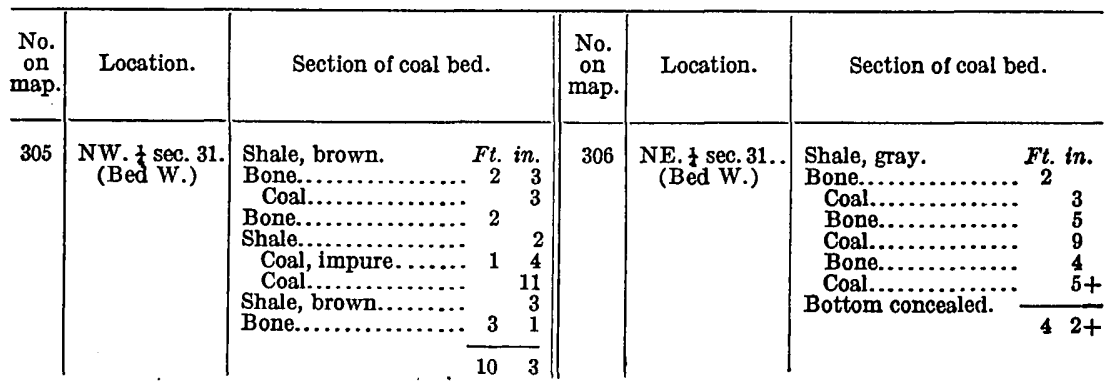


CONTRIBUTIONS TO ECONOMIC GEOLOGY, 1911, PART II.

Sections of coal beds in T. 12 N., R. 50 E.-Continued.

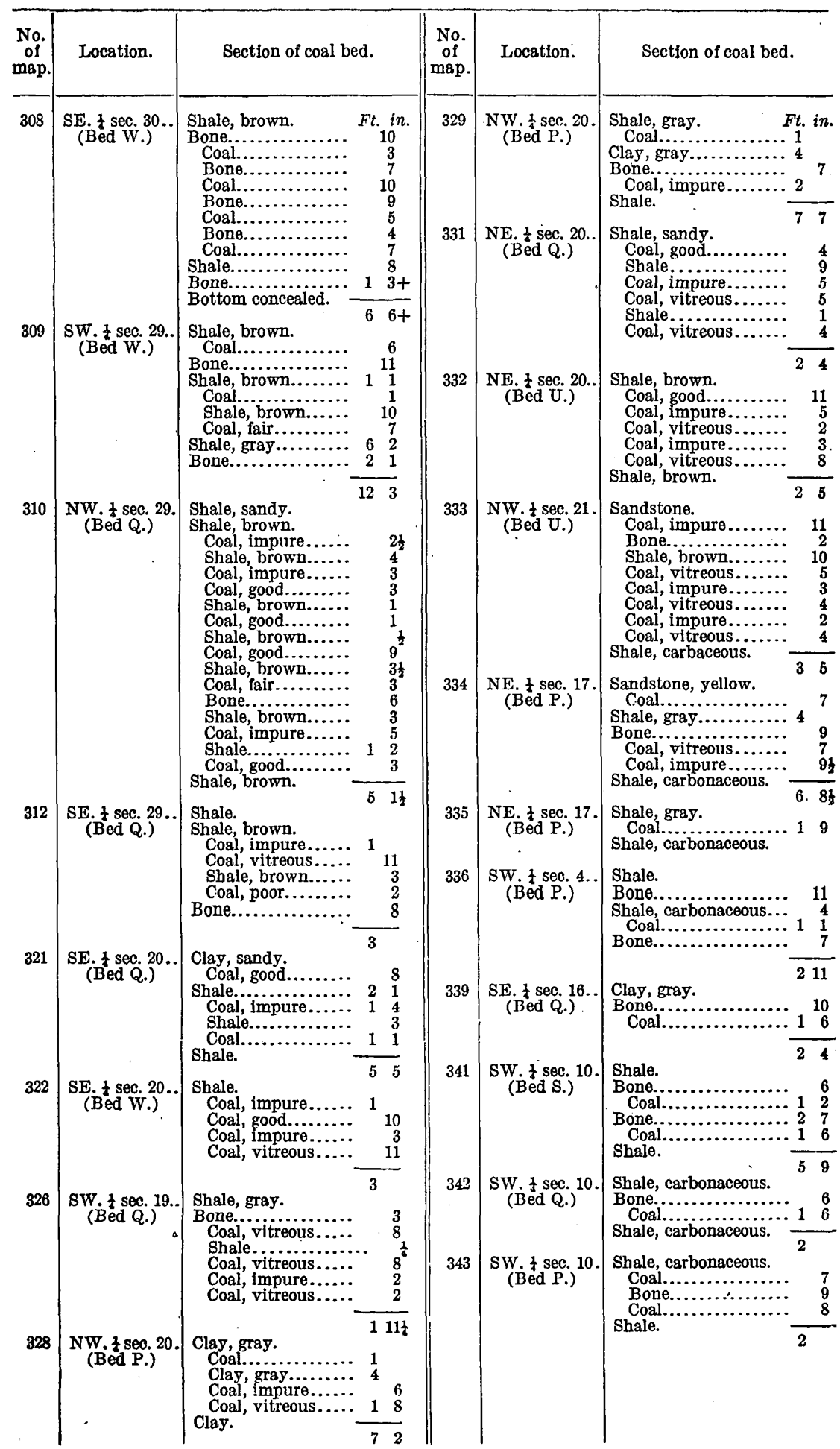




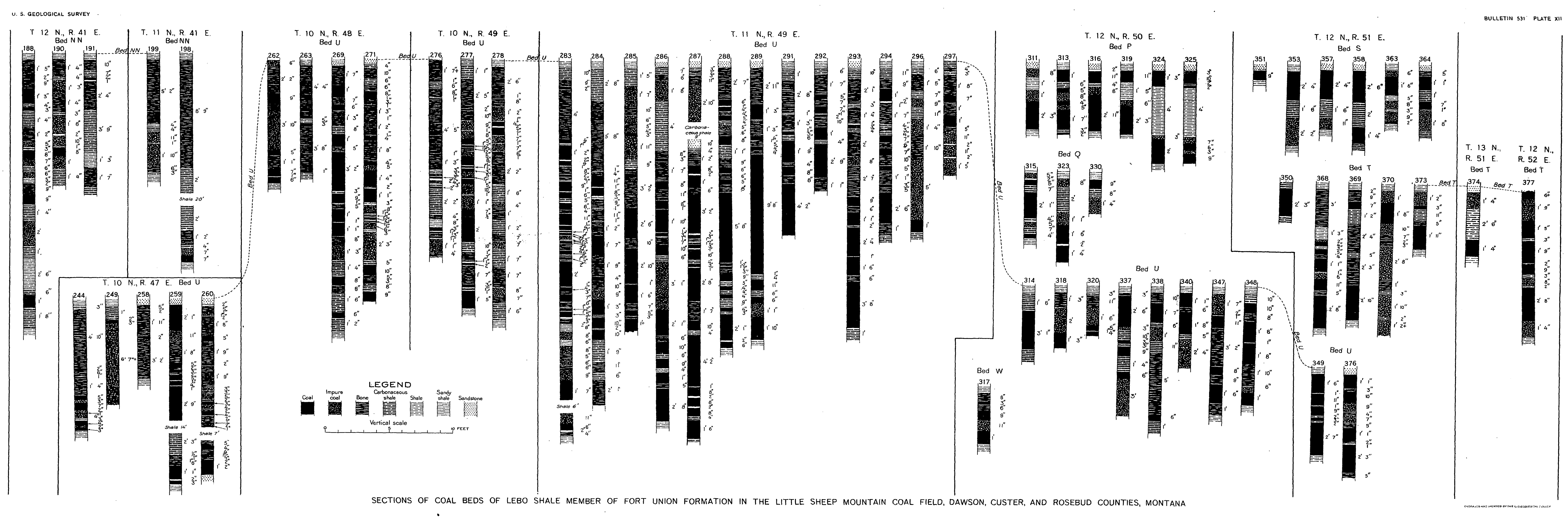


Sections of coal beds in T. 12 N., R. 50 E.-Continued.

\begin{tabular}{|c|c|c|c|c|c|}
\hline $\begin{array}{c}\text { No. } \\
\text { on } \\
\text { map. }\end{array}$ & Location. & Section of coal bed. & $\begin{array}{c}\text { No. } \\
\text { on } \\
\text { map. }\end{array}$ & Location. & Section of coal bed. \\
\hline 344 & $\begin{array}{l}\text { SE. I sec. } 10 . . \\
(B \text { ed } P .)\end{array}$ & 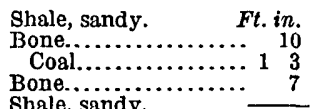 & 346 & $\begin{array}{l}\mathrm{SE}_{\text {. }} \frac{\mathrm{sec}}{1} \mathrm{10.} \\
\text { (Bed S.) }\end{array}$ & 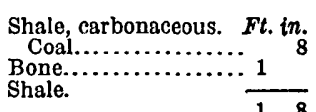 \\
\hline 345 & $\begin{array}{l}\text { SE. } \frac{1}{4} \text { sec. } 10 . . \\
(\text { Bed Q.) }\end{array}$ & $\begin{array}{lll}\text { Shale, sandy. } & 2 & 8 \\
\text { Coal................. } & 1 & 6 \\
\text { Shale. } & & \end{array}$ & & & \\
\hline
\end{tabular}

T. 12 N., R. 51 E. (FRACTIONAL).

Yellowstone River traverses T. 12 N., R. 51 E., and only its two northernmost tiers of sections are included in the area described in this report. The western part of the township, in which the Lebo shale member outcrops, is broken into nearly impassable badlands, but the eastern part, underlain by yellow beds of the Fort Union formation and by the Lance formation, is gently rolling and grass covered. The Lebo shale pinches out in this locality, as described above, and it is believed that the eastern limit of its deposition in this area is at about the center of this township. In the eastern part of this township the dip is little over $1^{\circ} \mathrm{SE}$.

Coal beds $\mathrm{S}, \mathrm{T}$, and $U$ are exposed in this township, and in the badland district they outcrop generally at the edge of the river. Bed S is of value in only a small area. It is lenticular, but nowhere contains more than 4 feet of coal, and this is generally split into two or more benches. (See sections 351,353, 357, 358, 363, and 364, Pl. XII.) The stratigraphic distance between beds $\mathrm{S}$ and $\mathrm{T}$ is 51 feet and between $T$ and $U 16 \frac{1}{2}$ feet. (See fig. 3, p. 165.) Bed T, in the western part of the township, carries about 3 feet of coal split up into small benches, but in sec. 9 (location 368) the bed contains a total of nearly 5 feet of coal. (See sections $350,368,369,370$, and 373, Pl. XII.) At this point it has been mined by more than 400 feet of drifts. The irregular and lenticular character of the bed (see section 368) rendered the enterprise unprofitable, however, and it was abandoned. No work has been done for several years, and the entry has caved and rendered the inner workings inaccessible. The bed decreases in quality and thickness to the east, although it generally carries over 2 feet of coal. Bed U contains 6 feet of coal in the western part of this township (see section $349, \mathrm{Pl}$. XII), but only 3 feet of coal in the central part, though in the valley of Cedar Creek it increases to 5 feet. (See section 376.) In the badland district to the west the coal beds are under a cover of 200 feet or more, but to the east the cover in few places is over 50 feet. 
Sections of coal beds in T. 12 N., R. $51 \mathrm{E}$.

[In addition to sections shown on Pl. XII.]

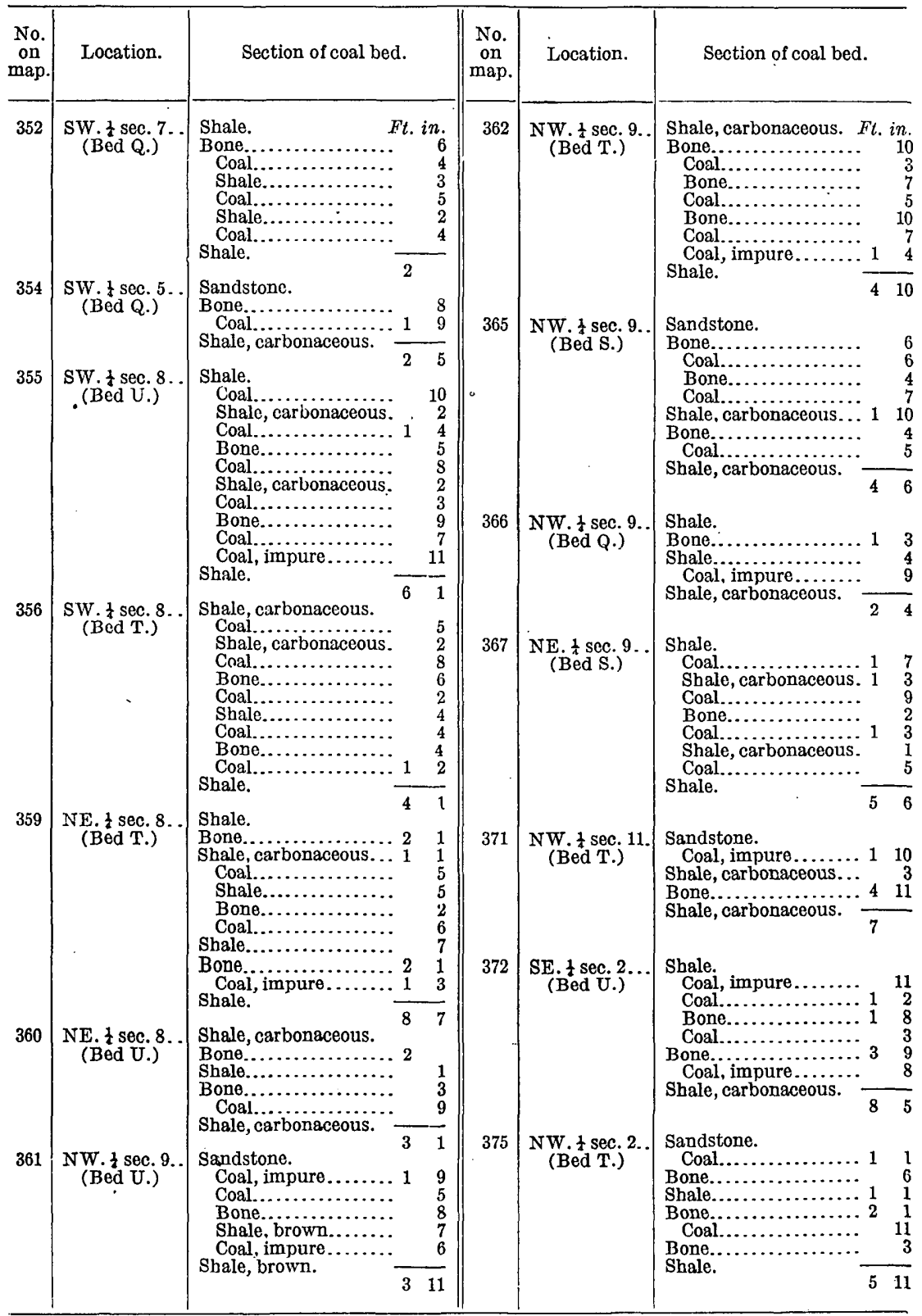


T. 12 N., R. 52 E. (FRACTIONAL).

Yellowstone River flows across T. 12 N., R. 52 E., so that only its extreme northwestern corner is included in the district described in this paper. The land is practically flat and is underlain by the Fort Union and Lance formations. These beds dip to the east, probably at an angle of $1^{\circ}$ or more.

Beds $\mathrm{T}$ and $\mathrm{U}$, which are separated by a stratigraphic distance of $16 \frac{1}{2}$ feet, cross sec. 6 of this township and in sec. 8 dip under the river and pass out of the district. ${ }^{1}$ For the most part they do not outcrop, but at the point at which they pass under Yellowstone River bed $T$ contains a total of more than 7 feet of coal in five benches. (See section 377, Pl. XII.) The cover is probably less than 50 feet thick throughout this area.

\footnotetext{
1 For description of this coal on east side of river, see Herald, F. A., The Terry lignite field, Custer County, Mont.: Bull. U. S. Geol. Survey No. 471, 1910, pp. 242 et seq.
} 
